\title{
Modelagem do Transporte e Retenção Larval da Anchoíta Engraulis anchoita na Plataforma Continental do Atlântico Sudoeste
}

Dissertação apresentada à Comissão de PósGraduação do Instituto Oceanográfico da Universidade de São Paulo, como parte dos requisitos para obtenção do Título de Mestre em Ciências, área de Oceanografia Física.

Orientador: Prof. Dr. Edmo José Dias Campos 


\title{
UNIVERSIDADE DE SÃO PAULO INSTITUTO OCEANOGRÁFICO
}

\section{Modelagem do Transporte e Retenção Larval da Anchoíta Engraulis anchoita na Plataforma Continental do Atlântico Sudoeste}

\author{
Ana Carolina Vaz
}

Dissertação apresentada ao Instituto Oceanográfico da Universidade de São Paulo, como parte dos requisitos para obtenção do Título de Mestre em Ciências; área: Oceanografia Física.

Aprovada em / / por:

Prof. Dr. Edmo José Dias Campos (Orientador)

Prof. Dr. do Instituto Oceanogr $\widetilde{A} ;$ fico da Universidade de SÃ£o Paulo

Prof. Dr ${ }^{a}$. June Ferraz Dias

$\operatorname{Prof}^{a}$. Dr ${ }^{a}$. do Instituto Oceanográfico da Universidade de São Paulo

Prof. Dr. José Henrique Muelbert

Prof. Dr. da Fundação Universidade Federal do Rio Grande 


\title{
Beira Mar
}

\author{
Cecília Meireles
}

Sou moradora de areias, de altas espumas: os navios passam pelas minhas janelas como o sangue nas minhas veias, como os peixinhos nos rios...

Não têm velas e têm velas;

e o mar tem e não tem sereias; e eu navego e estou parada, vejo mundos e estou cega, porque isto é mal de família, ser de areia, de água, de ilha...

E até sem barco navega quem foi para o mar fadada.

Deus te proteja, Cecilia, Que tudo é mar - e mais nada. 


\section{Sumário}

Agradecimentos iv

Resumo vi

Abstract vii

$\begin{array}{ll}\text { Lista de Figuras } & \text { ix }\end{array}$

Lista de Tabelas $\quad$ x

Lista de Abreviações $\quad$ xi

1 Introdução

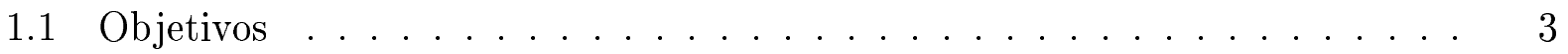

1.2 Organização do trabalho . . . . . . . . . . . . . . 4

2 Área de estudo 5

2.1 Descrição da área . . . . . . . . . . . . . . . . . . . . 7

2.2 O Rio da Prata, Lagoa dos Patos e suas bacias hidrográficas . . . . . . . 10

2.3 Resultados de Simulações Numéricas . . . . . . . . . . . . . . . . . . 10

2.4 Influência da Circulação no transporte e retenção do Ictioplâncton na PCAS 12

3 A anchoíta Engraulis anchoita 14

4 Materiais e Métodos $\quad 18$

4.1 Modelagem baseada no indivíduo . . . . . . . . . . . . . . . 18

4.2 Descrição do Modelo Biológico . . . . . . . . . . . . . . . . . . . . . 19

4.3 Campos de velocidade . . . . . . . . . . . . . . . . . . . . . . 23

4.3.1 Velocidade de Ekman . . . . . . . . . . . . . . . . . . 23

4.3 .2 Modelo Hidrodinâmico . . . . . . . . . . . . . . . . . . . . 25

4.4 Gráficos de retenção mensal e distribuição longitudinal das larvas . . . . . 27

4.5 Dados de Temperatura e Salinidade . . . . . . . . . . . . . . . . 29

4.5 .1 Temperatura . . . . . . . . . . . . . . . . . . . 29

4.5 .2 Salinidade . . . . . . . . . . . . . . . . . 30

4.6 Concentração de ovos e larvas de Engraulis anchoita . . . . . . . . . . . . 33 
5 Resultados $\quad 35$

5.1 Experimento com velocidades de Ekman . . . . . . . . . . . . 35

5.1 .1 Retenção e distribuição larval . . . . . . . . . . . . . . . . . . . . . . . . . . . . . 35

5.1 .2 Distribuição Longitudinal . . . . . . . . . . . . . . . . 38

5.1.3 Distribuição das larvas de $10 \mathrm{~mm}$ e campo de velocidades superficiais $\quad 40$

5.2 Experimento com velocidades do modelo hidrodinâmico com turbulência . 42

5.2 .1 Retenção e distribuição larval . . . . . . . . . . . . . . . . . . 42

5.2 .2 Distribuição Longitudinal . . . . . . . . . . . . . . . 46

5.2.3 Distribuição das larvas de $10 \mathrm{~mm}$ e campo de velocidades superficiais 48

6 Discussão $\quad 51$

6.1 IBM para os estágios iniciais do ciclo de vida da anchoíta na PCAS . . . . . 51

6.2 Influência do transporte de Ekman e da circulação no transporte e retenção

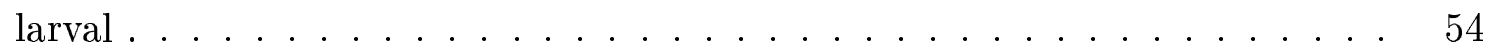

6.3 Comparação dos dados obtidos com dados observacionais . . . . . . . . . 57

6.4 Possibilidades de sobrevivência . . . . . . . . . . . . . . . . 61

6.4 .1 Salinidade . . . . . . . . . . . . . . . 61

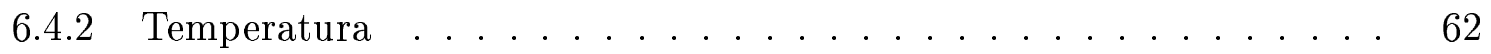

6.4 .3 Disponibilidade de alimento . . . . . . . . . . . 62

7 Conclusões e Sugestões $\quad 65$

8 Referências Bibliográficas $\quad 67$ 


\section{Agradecimentos}

Agradeço ao meu orientador, Dr. Edmo Campos, por todas as oportunidades a mim propiciadas e, especialmente, pela liberdade e confiança que ganhei para desenvolver meu trabalho. A todos labmonsters e labmonetes, por toda convivência, pelos milhares de cafés, conhecimentos compartilhados e brincadeiras que ajudavam a tornar o dia mais leve. Obrigada mesmo por toda ajuda que vocês me deram!

Agradeço a turma da pós do DOF de 2003: Ana, Rosio, Filipe, Fernanda, Eugênio, Edvard e Joselene, por todo o conhecimento, desespero, estudo e enjôo compartilhados durante as aulas, listas, provas e embarques.

Agradeço a todos os professores: Dr. Belmiro Castro Filho, Dr. Ilson da Silveira, Dr. Edmo Campos, Dr. Carlos Lentini e Dr. Luiz B. de Miranda, por tudo o que aprendi com vocês durante e fora das aulas.

Aos funcionários do IO, especialmente da biblioteca, das secretarias do Dept. de Física e da Pós-Graduação e ao Sr. Amaro, por toda a ajuda.

Agradeço a todos que, direta ou indiretamente, tornaram a realização deste trabalho uma realidade. Especialmente, a Dra. Carolina Parada, que mesmo sem me conhecer gastou parte de seu tempo me ajudando, sempre com muita boa vontade. Aos Profs. Drs. Elbio Palma, Alberto Piola e Ricardo Matano, pela disponibilização dos dados hidrodinâmicos provenientes de seu modelo, especialmente ao Elbio, por sua paciência em responder aos vários emails de dúvidas que lhe enviei. Ao M.Sc. Geoff Samuels (RSMAS), pelo programa de dispersão lagrangeana que serviu de base para o desenvolvimento de meu modelo.

À CPG, por ter aprovado uma banca tão peculiar e ter aberto mais as portas para trabalhos interdisciplinares. Agradeço aos membros da banca, Dr. José Henrique Muelbert (Zeca) e Dra. June Dias Ferraz, por terem aceito meu convite, e por todas sugestões dadas, que somente vieram a enriquecer este trabalho.

Ao Inter-American Institute for Global Change Research (IAI), à Fundação de Estudos e Pesquisas Aquáticas(FUNDESPA) e ao Conselho Nacional de Desenvolvimento Científico e Tecnológico (CNPq), pelas bolsas de mestrado concedidas. Ao Office of Naval Research (ONR,N00014-02-1-0295), ao IAI ( SACC/CRN-061), à Fundação de Amparo à Pesquisa do Estado de São Paulo (FAPESP, 2004/01950-3), à Diretoria de Hidrografia e Navegação da Marinha do Brasil e a SECIRM, pelo apoio ao projeto LA PLATA, do qual este trabalho é parte.

Agradeço aos novos amigos que fiz aqui em Sampa por sua amizade, especialmente a Dri, Manu, Quel, Fabricio e Marcos. Aos amigos de Campinas que continuaram me presenteando com seu carinhoso apoio. Às minhas amadas amigas spices: Ana, Ká, Hé e Vi, por tudo! O tempo, a distância e os obstáculos que tivemos que superar só nos aproximaram mais! Especialmente, agradeço a minha "room mate" Ana, pela paciência, bom senso e carinho, como você sabe, a nossa amizade foi essencial para enfrentar várias coisas por aqui!

Ao Fá, agradeço pelas milhões de coisas boas que trouxe para minha vida e por ser essa pessoa linda! Obrigada por ter tornado meus dias mais felizes! Agradeço também a sua 
família, por sempre terem me recebido tão bem!

Agradeço as pessoas que continuam tornando possível que meus sonhos se tornem realidade e batalhando ao meu lado em todos os momentos, minha mamy, Lucia, e minha tia, Angela. Não tenho palavras para agradecer todo amor, paciência e amizade de vocês. Novamente, Obrigada é muito pouco, e somente vocês sabem a dimensão disso. 


\section{Resumo}

O recrutamento de peixes pelágicos é o resultado de uma série de eventos contínuos no seu ciclo de vida, sendo que grande parte da variabilidade na mortalidade natural ocorre durante os estágios iniciais de desenvolvimento, relacionados a fatores ambientais. Nos estudos de populações pesqueiras é comum o uso de modelos hidrodinâmicos acoplados a modelos biológicos. Nesse contexto, um tipo de modelo merece destaque: o baseado no indíviduo (IBM - Individual Based Model). A Plataforma Continental Gaúcho-Uruguaia e Argentina comporta uma das mais importantes atividades pesqueiras do Atlântico Sudoeste. Com exceção dos resultados obtidos por alguns poucos trabalhos, a influência da circulação na distribuição de ovos e larvas nessa região é muito pouco entendida. Estudos anteriores sugerem que a predominância do transporte de Ekman em direção à costa no inverno/primavera impede a perda de ovos e larvas da área costeira e apontam a importância do deságue de água fluvial na região na criação de uma zona propícia para a retenção do ictioplâncton. Este trabalho apresenta resultados de um estudo englobando os padrões de circulação da região e de transporte de larvas nessa área. Isto foi feito através do desenvolvimento de um IBM para os estágios iniciais da Engraulis anchoita e o acoplamento deste a dois campos de velocidade superficial: a de Ekman, gerada pelos padrões de vento na região e a saída de um modelo hidrodinâmico 3D. Os resultados obtidos mostram que somente a deriva de Ekman não é suficiente para explicar o padrão de retenção larval observado na área de estudo. Os valores de retenção encontrados com a utilização da velocidade proveniente do modelo estão muito mais próximos aos observados. Maiores concentrações larvais foram obtidas no outono/inverno e menores na primavera/verão. Estes resultados estão diretamente relacionados à combinação dos efeitos dos padrões de vento da área com a influência das Correntes do Brasil e das Malvinas e do deságue continental na circulação sobre a plataforma. 


\section{Abstract}

Recruitment of pelagic fishes is the net result a series of continuous events in their life cycle. Most of the variability in natural mortality is thought to occur during the early stages of development and is related to environmental factors. The use of coupled physicalbiological modeling in the study of fisheries populations is very common and a particular type of model deserves special mention: the Individual Based Model (IBM). The Atlantic Southwestern Continental Shelf is one of the most productive fishing sites in the Western South Atlantic, but the processes involving the circulation in this area and its influence on eggs/larvae transport and retention are still poorly understood. Recent studies describe the spawning activity of anchovy and its relationship to oceanographic processes and suggest that predominant onshore Ekman transport, during the austral winter/spring, keeps the eggs and larvae in coastal areas. According to these studies, the river runoff contributes to the formation of a retention zone for planktonic organisms over the area. This work presents results of a study that considers both the circulation pattern and larval transport, throught the development of an IBM for the early stages of anchovy Engraulis anchoita. The model is coupled to two surface velocity fields: the Ekman drift, and the output of a 3D hydrographic model. The results show that just Ekman surface velocities are not able to explain the larval dispersion observed in this region. Retention values obtained with the model output are

much closer to observed values. Autumn and winter seasons present the highest values of retention. These results are due to the combined effect of the wind patterns registered in the area with the influence of the river runoff and the Brazil-Malvinas shelf circulation. 


\section{Lista de Figuras}

2.1 Localização da área de estudo: plataforma continental entre $39^{\circ} \mathrm{S}$ e $30^{\circ} \mathrm{S}$ (representada por azul claro $\ldots \ldots \ldots \ldots$

3.1 Anchoíta Engraulis anchoita (Cousseau \& Perrotta, 1998) . . . . . . . . . 15

3.2 Desenvolvimento larval da anchoíta (Ciechomski, 1965 apud Sanchez, 1989). 1) Larva récem eclodida 2) Larva de 2-5 dias 3) Larva de 3-4 dias 4) Larva de 10 dias 5) Larva de $6 \mathrm{~mm}$ 6) Larva de $13.5 \mathrm{~mm}$ 7) Juvenil de $44 \mathrm{~mm}$. . . .

4.1 Áreas de desove, localizadas entre as isóbatas de 20 a 200 metros. Área 1, Costa Riograndina $-31^{\circ} \mathrm{S}$ a $33,5^{\circ} \mathrm{S}$. Área 2, Costa Uruguaia $-33,5^{\circ} \mathrm{S}$ a $35^{\circ} \mathrm{S}$. Área 3, Região do Rio da Prata $-35^{\circ} \mathrm{S}-36^{\circ} \mathrm{S}$. Área 4, Costa Bonairense - $36^{\circ} \mathrm{S}$ $-38^{\circ} \mathrm{S} \ldots \ldots \ldots \ldots \ldots \ldots$

4.2 Velocidade superficiais de Ekman $\left(m s^{-1}\right)$ na área de estudo para o período de (A) verão; (B) outono; (C) inverno e (D) primavera. Geradas a partir da aplicação dos dados do ECMWF nas equações 4.18 e 4.19. As linhas pretas exibem as isóbatas de 20 e 350 metros . . . . . . . . . . . .

4.3 Velocidade superficiais provenientes do modelo hidrodinâmico $\left(\mathrm{ms}^{-1}\right)$ na área de estudo para o período de (A) verão; (B) outono; (C) inverno e (D) primavera. As linhas pretas exibem as isóbatas de 20 e 350 metros . . . . . . . .

4.4 Temperatura $\left({ }^{\circ} C\right)$ média superficial na área de estudo para o período de (A) verão, (B) outono, (C) inverno e (D) primavera. As linhas pretas exibem as isóbatas de 20 e 350 metros. Dados provenientes do Word Ocean Atlas . . . .

4.5 Salinidade média superficial na área de estudo para o período de (A) verão, (B) outono, (C) inverno e (D) primavera. As linhas pretas exibem as isóbatas de 20 e 350 metros. Dados provenientes do Word Ocean Atlas . . . . . . . .

4.6 Concentração de larvas de anchoíta por $100 \mathrm{~m}^{3}$ para o (A) verão, (B) outono, (C) inverno e (D) primavera. As linhas tracejadas exibem as isóbatas de 60 e 1000 metros. Os valores máximos e minímos de concentração variam entre as estações. Figuras provenientes do trabalho de Muelbert \& Sinque (1995) . .

5.1 Distribuição da frequência relativa de larvas retidas por mês. As linhas exibem a frequência relativa de larvas retidas em cada área (1,2,3 e 4). Experimento utilizando a velocidade superficial da deriva de Ekman . . . . . . . . 
5.2 Distribuição de frequência relativa de larvas não retidas por mês. As linhas exibem a distribuição de frequência relativa da área de desove (1,2,3 e 4) das larvas não retidas. Experimento utilizando a velocidade superficial da deriva

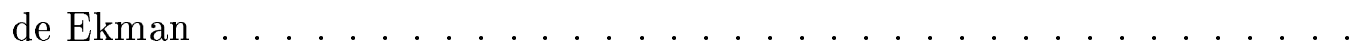

5.3 Distribuição de frequência relativa de larvas retidas por mês, nas áreas (A) 1; (B) 2 ; (C) 3 e (D) 4 . As linhas exibem a frequência relativa da área de desova $(1,2,3$ e 4$)$ das larvas retidas. Experimento utilizando a velocidade superficial da deriva de Ekman . . . . . . . . . . . . . . . .

5.4 Distribuição longitudinal da concentração mensal de larvas por $100 \mathrm{~km}^{2}$ na Área (A) 1; (B) 2; (C) 3 e (D) 4. Experimento utilizando a velocidade superficial da deriva de Ekman. . . . . . . . . . . . . . .

5.5 Distribuição das larvas de $10 \mathrm{~mm}$ (representadas em cinza) para os meses de (A) fevereiro ;(B) maio; (C) julho e (D) novembro. As setas indicam a direção e a intensidade $\left(m s^{-1}\right)$ do campo de velocidades superficiais. As linhas pretas representam as isóbatas de 20 e de 350 metros. Experimento utilizando a velocidade superficial da deriva de Ekman . . . . . . . . . . . .

5.6 Distribuição da frequência relativa de larvas retidas por mês. As linhas exibem a frequência relativa de larvas retidas em cada área (1,2,3 e 4). Experimento utilizando a saída do modelo hidrodinâmico . . . . . . . . . . . . .

5.7 Distribuição de frequência relativa de larvas não retidas por mês. As linhas exibem a distribuição de frequência relativa da área de desove (1,2,3 e 4) das larvas não retidas. Experimento utilizando a saída do modelo hidrodinâmico

5.8 Distribuição de frequência relativa de larvas retidas por mês, nas áreas (A) 1; (B) 2; (C) 3 e (D) 4. As linhas exibem a frequência relativa da área de desova (1,2,3 e 4) das larvas retidas. Experimento utilizando a saída do modelo

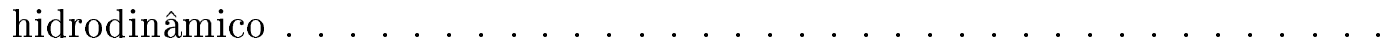

5.9 Distribuição longitudinal da concentração mensal de larvas por $100 \mathrm{~km}^{2}$ na Área (A) 1; (B) 2; (C) 3 e (D) 4. Experimento utilizando a saída do modelo

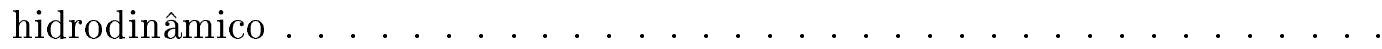

5.10 Distribuição das larvas de $10 \mathrm{~mm}$ (representadas em cinza) para os meses de (A) janeiro ;(B) maio; (C) setembro e (D) novembro. As setas indicam a direção e a intensidade $\left(m s^{-1}\right)$ do campo de velocidades superficiais. As linhas pretas representam as isóbatas de 20 e de 350 metros. Experimento utilizando a saída do modelo hidrodinâmico . . . . . . . . . . . . . . 


\section{Lista de Tabelas}

4.1 Número de larvas lançadas por mês no experimento utilizando velocidade superficial de Ekman . . . . . . . . . . . . . . . 25

4.2 Área $\left(\mathrm{em} \mathrm{km}^{2}\right)$ das regiões $1,2,3$ e 4 e de suas subdiviões $\ldots \ldots \ldots 29$ 


\section{Lista de Abreviações}

AC Água Costeira

ACAS Água Central do Atlântico Sul

AS Água Subantartica

AT Água Tropical

AVHRR Advanced Very High Resolution Radiometer

CB Corrente do Brasil

CBM Confluência Brasil-Malvinas

CM Corrente das Malvinas

ECMWF European Center for Medium-Range Forecast

FSTP Frente Sub-Tropical de Plataforma

IBM Individual Based Model

PCSAS Plataforma Continental Sudoeste do Atlântico Sul

PCGU Plataforma Continental Gaúcho-Uruguaia

PCAU Plataforma Continental Argentina-Uruguaia

PE Plataforma Externa

PI Plataforma Interna

PM Plataforma Média

POM Princeton Ocean Model

TSM Temperatura da Superfície do Mar

WOA World Ocean Atlas 


\section{Capítulo 1}

\section{Introdução}

O controle das características populacionais é um dos problemas fundamentais da biologia e que ainda permanece sem solução (Cushing, 1988). O estudo de populações de organismos marinhos iniciou-se no final do século XIX e os maiores desenvolvimentos conceituais neste campo podem ser traçados a partir desta época (Sinclair, 1988). Esse estudo ganhou grande importância devido ao declínio dos estoques mundiais, o qual foi causado por uma extrema pressão de pesca ocorrida no início do século XX (Cushing, 1988).

Análises de depósitos de escamas em sedimentos apontam que as populações de diversos peixes, especialmente de anchoítas e sardinhas têm apresentado grandes flutuações desde o último século, indicando que essas variações não estão relacionadas apenas à pesca intensiva dessas espécies, visto que já ocorriam antes do surgimento da pesca de larga escala (Soutar \& Isaacs, 1974; De Vries \& Piarcy, 1982; Baumgartner et al., 1992). Fatores ambientais e bióticos poderiam então ser os responsáveis por estas flutuações (Bakun, 1996; Huggett et al., 2003).

Hjort (1914) foi um dos pioneiros a lidar com a complexa questão da variabilidade nas populações marinhas ligada a fatores ambientais, e criou duas importantes generalizações sobre o sucesso no recrutamento de um determinado ano: 1) o mesmo é determinado durante os estágios anteriores ao recrutamento para a pesca; e, 2) não é uma função simples da produção de ovos. O autor discutiu múltiplas causas das flutuações interanuais registradas na mortalidade durante os estágios iniciais de vida, e levantou duas razões principais: variações na disponibilidade de comida em estágios críticos no desenvolvimento larval, e transporte de ovos e larvas para fora de zonas apropriadas ao seu desenvolvimento, causado por variabilidades nos padrões de circulação. Este foi um dos primeiros autores que considerou a deriva larval como processo chave no recrutamento dos estoques pesqueiros.

Alguns autores "refinaram" as idéias incialmente propostas por Hjort, como Harden Jones, que em 1968 desenvolveu um sistema para explicar a migração e criou o chamado "triângulo de migração". Neste triângulo há uma divisão em três segmentos básicos: as áreas de desova, as áreas de crescimento e o estoque adulto. Dentro de uma primeira etapa, o deslocamento passivo dos ovos e larvas da área de desova para a área de crescimento é dependente das correntes marinhas, caracterizado como um processo denatante (a favor das correntes); o recrutamento, que caracteriza o processo de incorporação dos juvenis ao estoque adulto, seria um processo contranatante, ou seja, de natação livre contra-correntes. 
Fechando o ciclo, teríamos o deslocamento ativo (contranatante) dos adultos em direção às áreas de desova.

A partir desta teoria, constatou-se que diversos organismos marinhos, como peixes, moluscos e crustáceos, possuem um complexo ciclo de vida, sendo organismos planctônicos nos primeiros estágios de desenvolvimento, nos quais seu deslocamento é determinado por mecanismos de transporte físico. Os processos físicos que afetam o transporte larval consistem de uma ampla extensão de escalas temporais e espaciais do movimento oceânico, incluindo difusão turbulenta e molecular, marés, mistura por tempestade, correntes dirigidas pelo vento, ondas internas, vórtices de meso-escala e circulação geral de larga escala (Okubo, 1994).

As áreas de desova da maioria das espécies de peixes são locais definidos, e a escolha correta destes locais é essencial para que ovos e larvas sejam carregados ou mantidos em locais ideais, como áreas costeiras protegidas, baías, estuários (Sinclair, 1988). Durante este processo de transporte das áreas de desova aos locais de crescimento podem ocorrer falhas, que causam a dispersão das larvas planctônicas e sua morte. Assim, de acordo com a circulação nas áreas de desova tem-se um maior ou menor sucesso no recrutamento dos organismos, e consequente sucesso reprodutivo (Hill, 1991). Desta forma, o deslocamento ou a retenção durante o período larval é muito importante na história de vida destes organismos, pois provê uma base geográfica para a distribuição do estoque, ajuda a estabelecer diferenças entre os mesmos e mantém a competição entre espécies. Para compreender totalmente a biologia de um estoque pesqueiro, a deriva larval deve ser adequadamente descrita (Cushing, 1988).

O recrutamento das espécies de peixes pelágicos mostra-se um problema complexo, onde diferentes fatores como a circulação, temperatura e salinidade oceânicas, clima, disponibilidade de alimento e nutrientes influenciam seu sucesso. Diversas pesquisas vêm sendo realizadas buscando um maior entendimento destes processos. Relações empíricas lineares entre fatores ambientais e a abundância não se mostram satisfatórias (Bakun, 1996; Huggett et al., 2003), enquanto que uso de métodos de análises não lineares tem sido introduzido recentemente em ecologia marinha e ciência pesqueira, mostrando bons resultados. A partir da aplicação destes métodos, surgiram algumas teorias que envolvem um maior número de váriaveis e que se mostram promissoras, como as de Cury e Roy (1989), da "janela ambiental ótima", que integra vários processos e a de Bakun (1996), a qual sugere que enriquecimento, concentração e retenção são importantes processos para o sucesso do recrutamento de peixes costeiros pelágicos.

A solução deste problema também tem envolvido a criação de novas técnicas que estejam aptas a explorar adequadamente todas as suas complexidades. O acoplamento de modelos hidrodinâmicos a modelos biológicos, é uma ferramenta que vem sendo amplamente utilizada para ajudar na resolução deste problema. O primeiro fornece condições ambientais como temperatura, salinidade, campo de velocidades para o segundo, que resolve os processos biológicos, e os resultados obtidos são condizentes com situações reais (Lyne \& Thresher, 1994; Davis \& Lyne, 1994; Doney et al., 2001; Lima et al., 2002a e b; Skongen et al., 2003; Adlandsvik et al., 2004; Sentchev \& Korotenko, 2004). Dentre esses modelos, os modelos baseados no indivíduo (IBM), os quais tratam indivíduos como entidades únicas e discretas, com atributos próprios como tamanho, posição, peso, que mudam durante o seu ciclo de vida e de acordo com condições ambientais, têm se mostrado particularmente eficiente. Este tipo 
de ferramenta tem a capacidade de acomodar diferentes aspectos relacionados ao sucesso do recrutamento e vem sendo amplamente utilizada no estudo de biologia pesqueira em diferentes partes do mundo ( Crowder et al., 1992; Letcher et al., 1996; Hinrichsen et al., 2002; Mullon et al., 2002; Allain et al., 2003; Gwenhael et al.,2003; Huggett et al., 2003; Parada et al.,2003; Pedersen et al. 2003 e Bartsch \& Coombs, 2004), mas nunca foi utilizado em estudos de populações marinhas na costa brasileira.

A Plataforma Continental Sudoeste do Atlântico Sul comporta uma das mais importantes atividades pesqueiras do Atlântico Sudoeste (Garcia et al. 2001). Somente para o sul do Brasil a comunidade ictioplanctônica conhecida é constituida por cerca de 88 espécies de peixes, distribuídas em 48 famílias (Sinque \& Muelbert, 1996). Com excessão dos resultados obtidos por poucos trabalhos, a influência da circulação na distribuição de ovos e larvas nesta região é pobremente entendida. Lima \& Castello (1995) descreveram a atividade de desova de Engraulis anchoita e a relacionaram com os processos oceanográficos da região. Os autores sugerem que a predominância do transporte de Ekman em direção à costa no inverno e primavera impede a perda de ovos e larvas da área costeira. Busoli (2001) concluiu que o deságue de água fluvial que ocorre na região é de extrema importância na criação de uma zona propícia para a retenção do ictioplâncton, enquanto Soares (2003) observou a formação de uma zona com correntes residuais fracas nesta região, a qual favorece a acumulação de partículas passivas, como plâncton, ovos e larvas de peixes. Segundo o autor, a existência desta área ajudaria a explicar porque alguns peixes ocorre sucesso para os indivíduos de espécies de peixes que desovam no outono.

A dissertação a ser desenvolvida propõe um estudo englobando os padrões de circulação da região e de transporte de larvas nesta área, dado que o conhecimento desta dinâmica é de imensa importância para o gerenciamento dos recursos pesqueiros do sul do Brasil. Isto será feito através do desenvolvimento de um IBM para os estágios iniciais de Engraulis anchoita e o acoplamento deste a diferentes campos de velocidade superficial para simular o transporte e retenção dos ovos e larvas.

\subsection{Objetivos}

O objetivo geral deste trabalho é o desenvolvimento de um IBM que simule os processos ocorrentes durante a fase inicial de desenvolvimento da anchoíta, na Plataforma Continental Sudoeste do Atlântico, dentre os quais estão a desova, crescimento e transporte larval, tendo em vista que os resultados obtidos com o modelo podem responder diversas perguntas existentes sobre a dispersão larval e recrutamento na região. Além disso, o desenvolvimento e aplicação deste tipo de ferramenta na oceanografia brasileira ainda é inédito, e a metodologia a ser descrita poderá vir a ser aplicada com sucesso em diversos outros estudos desenvolvidos na costa brasileira.

Desta forma, utilizando os dados provenientes do IBM, os objetivos específicos do projeto são:

- Estudar os padrões sazonais de transporte e retenção de larvas na plataforma continental 
- Verificar a origem das larvas retidas em cada área da plataforma continental (PC Brasileira, Uruguaia e Argentina)

- Estimar em que região da plataforma (plataforma interna, média e externa) há maior concentração de larvas

- Comparar os padrões acima quando o modelo é alimentado por velocidades superficiais de Ekman e por velocidades provenientes de um modelo hidrodinâmico, o qual simula mais fielmente o campo de velocidades superficiais encontrado na região

- Discutir as chances de sobreviência larval em cada área, com base em dados de temperatura, salinidade e disponibilidade de alimento

\subsection{Organização do trabalho}

A seguir é exibida a forma como a dissertação está organizada:

- Capítulo 1 - traz a introdução geral do trabalho, apresenta os objetivos gerais e específicos do mesmo

- Capítulo 2 - apresenta a área de estudo, com suas características físicas, biológicas, e padrões sazonais de circulação

- Capítulo 3 - realiza uma breve descrição da anchoíta Engraulis anchoita

- Capítulo 4 - trata da metologia envolvida na criação do IBM e descreve os dados utilizados no trabalho. Introduz os modelos baseados no indivíduo, descreve as características do modelo desenvolvido neste trabalho, apresenta os dados de velocidade que o alimentaram. Descreve os dois experimentos realizados bem como os processos de normalização aplicados aos dados de saída.

- Capítulo 5 - exibe todos os resultados obtidos

- Capítulo 6 - traz a discussão dos dados exibidos no Capítulo 5

- Capítulo 7 - mostra as conclusões deste trabalho e as recomendações para próximos estudos 


\section{Capítulo 2}

\section{Área de estudo}

A área a ser descrita abrange a plataforma continental adjacente às costas da Argentina, Uruguai e Brasil, entre as latitudes de $39^{\circ} \mathrm{S}$ e $30^{\circ} \mathrm{S}$, conforme figura 2.1 .

A Lagoa dos Patos e a plataforma adjacente comportam uma das mais importantes atividades pesqueiras no Atlântico-Sudoeste (Garcia et al., 2001). Cerca de 3500 pescadores artesanais (Reis \& D'Incao, 2000) e 3000 pescadores industriais estão permanentemente ou temporariamente envolvidos em atividades pesqueiras nesta região (Haimovici et al., 1996). Os valores de captura da pesca artesanal atingem a média de $182.8 \mathrm{~kg} / \mathrm{ha}$ /ano (Castello, 1985).

A plataforma continental entre $29^{\circ} \mathrm{S}-34^{\circ} \mathrm{S}$ está sob a influência da Convergência Subtropical. A composição e abundância de espécies, a estrutura pelágica, a distribuição espacial de comunidades e suas interações tróficas, bem como a produção biológica, estão largamente controladas pela dominância sazonal de distintas massas de água sobre a plataforma e o talude. A descarga fluvial do Rio da Prata e da Lagoa dos Patos torna-se importante no inverno e no verão. Particularmente entre Rio Grande e Chuí, condições oceanográficas favorecem uma alta produção biológica, que resulta num considerável e ainda quase inexplorado estoque de pequenos peixes pelágicos, e em recursos demersais altamente produtivos, mas sobre-explorados (Castello et al., 1996).

Devido à influência da água subantártica, rica em nutrientes e à descarga fluvial da Lagoa dos Patos e do Rio da Prata, as taxas de clorofila a e de produção primária são maiores no final do inverno e na primavera (Ciotti et al., 1995). A avaliação de dados de produção primária sugere taxas anuais moderadas a altas de produção primária $\left(160 \mathrm{gCm}^{-2} \mathrm{y}^{-1}\right)$ (Odebrecht \& Garcia, 1996), que sustentam uma produção secundária também alta. Há cerca de 40 espécies da comunidade pelágica nectônica na plataforma continental (Castello et al., 1996).

As larvas de alguns dos peixes mais abundantes nesta área, engraulídeos e mictopídeos, são encontradas na plataforma continental sul do Brasil durante o verão e o início da primavera, atribuindo-se sua presença à ventos favoráveis a subsidência (Lima \& Castello, 1995). Esses ventos são os do quadrante sul, e o transporte de Ekman que eles criam na camada superficial mantém os ovos e larvas nas áreas costeiras. Soares \& Moller (2001) apontam que observações horárias registradas na plataforma continental sul brasileira mostram fortes mudanças nos ventos e eventos de ressurgência, mesmo enquanto a média mensal do vento é favorável à subsidência. Esses eventos podem ser fatais para as larvas, por favorecerem 


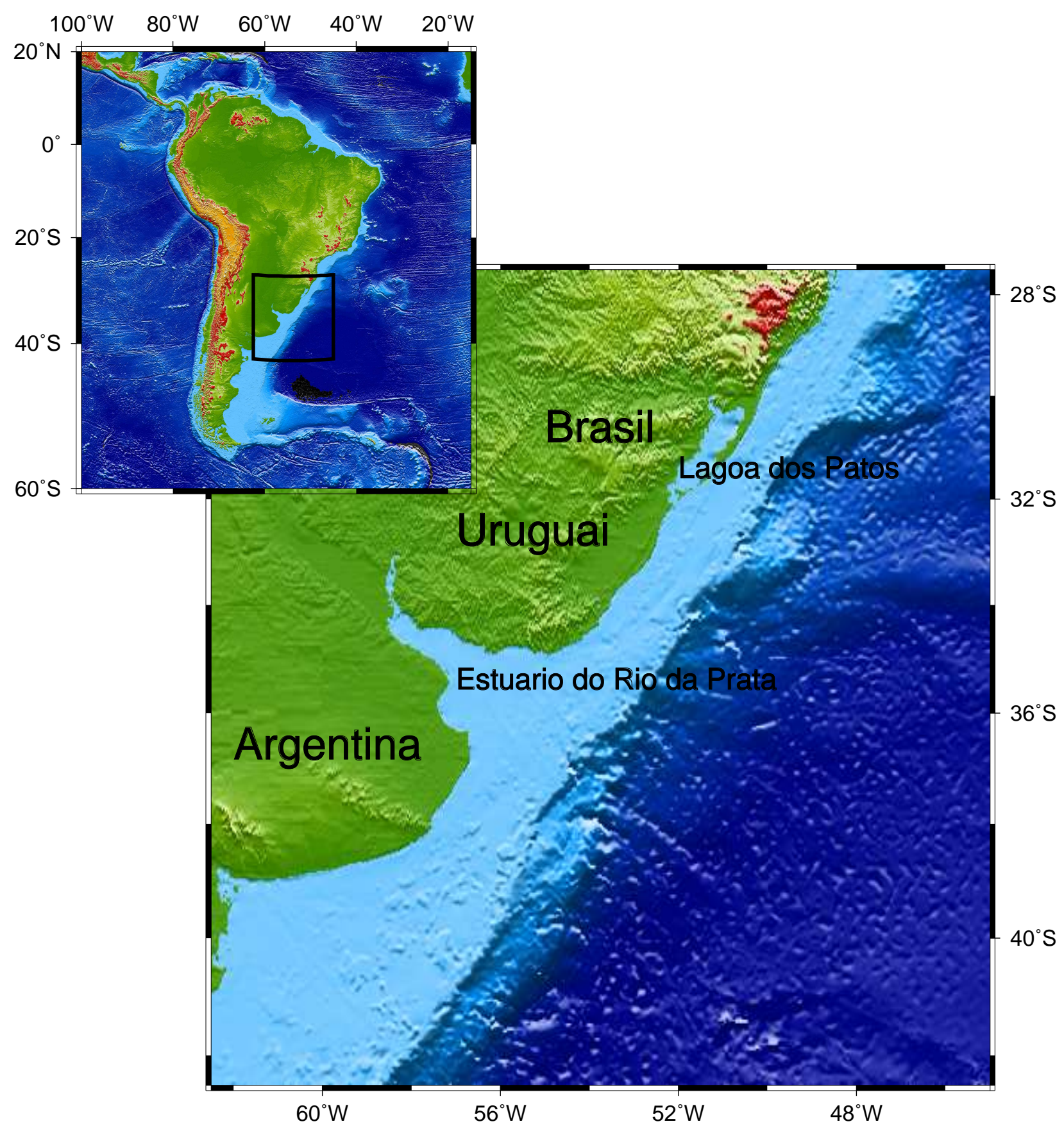

Figura 2.1: Localização da área de estudo: plataforma continental entre $39^{\circ} S$ e $30^{\circ} S$ (representada por azul claro) 
o transporte em direção ao oceano aberto. O mecanismo que parece evitar essa dispersão larval é a circulação baroclínica induzida pela saída de água doce do Rio da Prata (Soares, 2003).

\subsection{Descrição da área}

Esta região apresenta uma configuração da linha de costa praticamente retilínea seguindo uma orientação principal Nordeste-Sudeste. A topografia nesta região segue a tendência de um alargamento gradual da plataforma continental em direção ao sul. Entre $28^{\circ} \mathrm{S}$ (Cabo de Santa Marta) e o Cabo Polônio $\left(34,4^{\circ} \mathrm{S}\right)$ no Uruguai, ela recebe a denominação de Plataforma Continental Gaúcho-Uruguaia (PCGU) (Castro Filho \& Miranda, 1998). Sua plataforma continental possui configuração praticamente paralela à linha de costa e uma topografia bastante suave. Na porção norte, a plataforma continental é mais estreita. Ao longo da costa gaúcha, encontra-se a Lagoa dos Patos, cuja desembocadura localiza-se em Rio Grande.

O restante da área corresponde à Plataforma Continental Argentino-Uruguaia (PCAU) ou Região estuarina do Prata. Neste local a configuração da linha de costa adquire uma forma afunilada, com características de estuário clássico. O estuário do Prata estende-se por $320 \mathrm{~km}$ segundo um eixo de orientação sudeste, aumentando sua largura de cerca de 2 $\mathrm{km}$ no interior do estuário para cerca de $230 \mathrm{~km}$ na sua desembocadura, entre Punta del Este (Uruguai) e Punta Rasa (Argentina). A plataforma continental nesta região mantém-se ampla, com isóbatas seguindo a orientação principal de nordeste-sudoeste (Pimenta, 2001).

A circulação desta região depende da propagação de ondas de maré, forçantes do vento, descarga fluvial e a influência das correntes de contorno oeste próximas (Palma et al., no prelo)

A maré na PCGU tem pequena amplitude $(\eta<0.5 \mathrm{~cm})$, por esta região estar próxima a um ponto anfidrômico. Zavialov et al. (2002) verificaram que as marés diurnas são mais importantes que as semi-diurnas enquanto Castro Filho e Miranda (1998) observaram que para a região da plataforma continental sudeste $\left(28.5^{\circ} \mathrm{S}\right.$ à $\left.23^{\circ} \mathrm{S}\right)$ as marés semidiurnas respondem por mais de $50 \%$ da variabilidade de correntes perpendiculares à costa. Já a região da PCAU apresenta amplitudes de maré maiores. A maior parte da energia cinética das correntes (80\%) na plataforma Argentina ao largo de Puerto Madryn ( $44^{\circ} \mathrm{S}$ ) se concentra em períodos diurnos e semi-diurnos, em função da grande influência das marés para esta área (Rivas, 1997). O’Connor (1991) demonstrou, usando experimentos numéricos, que a amplitude de maré pode chegar a $0.9 \mathrm{~m}$ na costa argentina do estuário do Prata.

A climatologia nesta região apresenta um marcante padrão espacial e temporal, e é fortemente marcada pela influência de sistemas ciclônicos migratórios e das frentes associadas. Ventos de sul tendem a afetar mais a parte sul da área de estudo e os de nordeste dominam ao longo do ano na parte norte da região (Moller \& Castaing, 1999). Durante o verão e a primavera, os ventos de nordeste são predominantes, enquanto durante o outono e inverno os ventos de sul se tornam mais frequentes (Moller et al., 1991). Segundo Soares \& Moller (2001), estes ventos parecem exercer um efeito crucial na circulação da PCGU, pois as condições de maior estratificação encontradas pelos autores durante cruzeiros oceanográficos, foram na primavera e no verão, juntamente com a ocorrência de ventos nordeste, os 
quais são favoráveis a ressurgência.

A circulação na PCGU, segundo Pereira (1989), reverte com os ventos, sendo em direção ao sudoeste durante o verão austral e para o nordeste no inverno austral. O autor ressalta que nesta última estação o fluxo em direção ao norte é fortalecido pelos ventos de sudoeste adicionado aos efeitos dos gradientes de densidade e da força de Coriolis.

Zavialov et al. (1998) desenvolveram um modelo inverso para a região, baseado na equação de conservação de calor, e encontraram uma corrente fluindo para o norte na plataforma interna durante todo o ano, enquanto na plataforma externa há um fluxo forte para o sul, o qual é causado pela Corrente do Brasil. Este fluxo direcionado para norte foi atribuido à propagação costeira de águas do Rio da Prata.

Trabalhos realizados com dados de correntografia ao largo da cidade de Rio Grande $\left(32^{\circ} \mathrm{S}\right)$ reveleram um fluxo predominantemente barotrópico, composto por uma componente variável correlacionada a variabilidade do vento e outra persistente associada a um fluxo residual de poucos centímetros por segundo ao longo da costa. Os resultados também confirmaram a presença de uma corrente dirigida para nordeste na PCGU, chamada de "Corrente de Rio Grande" e associada às descargas fluviais do Rio da Prata e da Lagoa dos Patos. Ao contrário da plataforma argentina, cerca de $60 \%$ da energia cinética destes registros se concentrou nos períodos associados às forçantes meteorológicas e somente $8 \%$ foi associada às marés (Neto, 1999; Zavialov \& Möller, 2000; Zavialov et al., 2002).

Um dos fatores determinantes na circulação desta região é a proximidade da Confluência Brasil-Malvinas, uma frente pronunciada formada pela convergência das águas frias e relativamente doces da Corrente das Malvinas (CM) que flui em direção ao norte e as águas quentes e salinas da Corrente do Brasil (CB) fluindo em direção ao sul. Normalmente em $38^{\circ} \mathrm{S}$ a $\mathrm{CB}$ se separa da costa e vira seu fluxo na direção perpendicular a mesma, juntamente com a CM (Zavialov et al., 1998).

Essa zona de separação sofre grandes variações, como mostrado por diversos trabalhos. Olson et al. (1988) analisaram uma série de dados AVHRR da região, cobrindo o período de julho de 1984 e junho de 1987. Os autores, com base em análises estatísticas, concluíram que para a $\mathrm{CB}$ o ponto de separação é em média $35,8^{\circ} \mathrm{S}$, com um desvio padrão de $1,1^{\circ}$. Para a CM é em torno de $38,8^{\circ} \mathrm{S}$, com um desvio de $0,9^{\circ}$. Durante os meses de inverno, o ponto de separação da CM e da CB está localizado mais ao norte e durante o verão mais ao sul. Souza \& Robinson (2004), utilizando uma série de dados de AVHRR (1982-1995) e dados lagrangeanos provenientes de bóias, descreveram o comportamento da CB. Segundo os autores, o ciclo de oscilação sazonal da CB é claro: nos meses de verão a corrente atinge as maiores latitudes em direção ao sul, sendo o máximo registrado de 43,8 ${ }^{\circ} \mathrm{S}$ em fevereiro/1984. Já nos meses de inverno, a corrente tende a atingir as latitudes mais ao norte, com o extremo visto de $28,3^{\circ} \mathrm{S}$ em outubro/1987. Wainer et al. (2000), compararam dados de modelagem com dados observacionais na região. Os autores obtiveram em seu modelo um marcado ciclo sazonal, com a CM durante o inverno atingindo os pontos mais ao norte e apresentando o maior transporte. Durante o verão, é a CB que atinge os pontos mais ao sul e apresenta o maior transporte. Segundo Olson et al. (1988), as mudanças no ponto de separação e a extensão geométrica das correntes no sistema Brasil-Malvinas é muito maior que o observado na Corrente do Golfo e Kuroshio. Isso se dá especialmente pelas diferenças na topografia da quebra de plataforma entre as regiões dessas correntes, que na Argentina é praticamente 
constante quando comparada com as mudanças abruptas do relevo das duas maiores correntes de contorno do hemisfério norte. Outros fatores que também podem influenciar nas mudanças da zona de separação seriam: variações na tensão de cisalhamento do vento sobre o Atlântico Sul; varições na Corrente das Malvinas provocadas por mudanças da Corrente Circumpolar Antártica; e, a propagação para oeste de longos meandros iniciados na extensão da corrente de contorno.

A CB transporta Água Tropical (AT) para o sul e a CM transporta Água Subantártica (AS) para o norte. Na Confluência, há a formação daÁgua Central do Atlântico Sul (ACAS) que, após um giro anti-ciclônico nas camadas de fundo, chega até a PCGU fluindo para o sul (Garcia, 1997). O deságue continental propicia a formação da Água Costeira (AC) (Piola et al., 2000).

Piola et al. (2000) apresentaram uma descrição da estrutura termohalina costeira, para a plataforma continental média e externa de $40^{\circ} \mathrm{S}$ a $20^{\circ} \mathrm{S}$. Os autores verificaram a presença de duas massas de água na região costeira bem definidas e distintas, a Água Subtropical de Plataforma (relativamente quente e salina) e a Água Subantártica de Plataforma (relativamente fria e pouco salina). Estas massas são formadas pela mistura de águas da CBM e as águas de baixa salinidade oriundas do Rio da Prata e da Lagoa dos Patos e caracterizam a Frente Sub-Tropical de Plataforma (FSTP), que em média se localiza próxima a $33^{\circ} \mathrm{S}$.

Um dos aspectos mais notáveis da circulação de larga escala na área de estudo, depois da Confluência Brasil-Malvinas, é a presença de grandes extensões de águas de baixa salinidade na zona próxima à costa. Parte desta água é originada do Rio da Prata e da Lagoa dos Patos, mas parte dela é originada da costa da Patagônia (Soares, 2003).

O padrão médio de circulação ao longo da plataforma argentina tem sido descrito por médias de modelos teóricos baseados na tensão de cisalhamento superficial do vento, gradientes horizontais de densidade e resultados de modelo. Esse padrão é considerado um fluxo direcionado para NNE, com velocidades variando entre 0,1 e $0,2 \mathrm{~ms}^{-1}$ (Brand horst \& Castello, 1971; Forbes \& Garrafo, 1988; Bakun \& Parrish, 1991; Rivas, 1997).

Este fluxo parece ser dirigido pelos ventos de oeste (Forbes \& Garrafo, 1988; Bakun \& Parrish, 1991; Piola et al., 2000), enquanto efeitos de flutuação são pobremente entendidos. A latitude de $37^{\circ} \mathrm{S}$ pode ser considerada o limite norte desta corrente, pois ao norte desta latitude o fluxo na plataforma adquire uma componente zonal significante, provavelmente associada ao enfraquecimento dos ventos de oeste (Piola et al, 2000), e à efeitos decorrentes da descarga do Rio da Prata e da Confluência Brasil-Malvinas (Soares, 2003).

A penetração das águas do Rio da Prata para o norte ocorre durante todo o ano, sendo menos significante durante o verão e alcançando seu máximo de extensão durante o inverno (Piola et al., 2000). A ocorrência de água do Rio da Prata foi observada em $24^{\circ} \mathrm{S}$, durante um cruzeiro hidrográfico realizado no inverno (Campos et al. 1996). Perto de 3 graus de latitude ao norte da desembocadura do Rio da Prata, a descarga da Lagoa dos Patos supre a água menos densa necessária para fortalecer a propagação das águas fluviais para o norte.

Resultados numéricos obtidos por Soares (2003), Pimenta (2001) e Ghisolfi (2001, apud Soares, 2003), mostram que a intrusão de águas do Rio da Prata na plataforma continental sul-brasileira, em direção ao norte é em grande parte determinada pelos ventos. 


\subsection{O Rio da Prata, Lagoa dos Patos e suas bacias hidro- gráficas}

Localizado na costa leste da América do Sul, o Rio da Prata é alimentado pela segunda maior bacia de drenagem do continente, o que em área corresponde a um total de 3.100.000 $\mathrm{km}^{2}$, estendendo-se pelos territórios da Bolívia, Brasil, Argentina, Paraguai e Uruguai. Suas principais unidades hidrográficas são os Rios Paraguai, Paraná e Uruguai. O Rio Paraná é o que possui a maior descarga, em média $16000 \mathrm{~m}^{3} \mathrm{~s}^{-1}$. O Rio Uruguai apresenta uma média de $5800 \mathrm{~m}^{3} \mathrm{~s}^{-1}$. Os transportes de volume máximos e mínimos ocorrem no outono e na primavera para o Paraná e no inverno e verão para o Uruguai (Framiñan \& Brown, 1996).

A descarga do Rio da Prata é geralmente avaliada pelo transporte resultante dos seus maiores tributários e corresponde a um valor médio de $22 \times 10^{3} \mathrm{~m}^{3} \mathrm{~s}^{-1}$ (Framiñan \& Brown, 1996). A vazão do Rio da Prata apresenta variações sazonais, e as diferenças entre os períodos de máxima (abril a julho) e mínima descargas (dezembro a março) são de aproximadamente $22 \%$ (Guerrero et al., 1997).

A sua bacia de drenagem está situada em regiões nas quais as anomalias de precipitação estão fortemente relacionadas à Oscilação Sul, conforme reportam diversos estudos, como os de Kousky \& Cavalcanti (1983), Ropelewski \& Halpert (1987), Rao \& Hada (1990), Grimm et al. (1998 e 2000). Estes apontam um aumento na precipitação na região em eventos positivos da OS, i.e., durante eventos de El Niño.

Essa tendência de maior precipitação se reflete no comportamento dos rios na região, como no Rio Uruguai, que apresenta uma tendência de descargas abaixo da média em anos de "La Niña", enquanto eventos de "El Niño" impõem uma suave tendência de aumento desta (Mechoso \& Pérez, 1992). Aceituno (1988) também identificou uma correlação negativa entre a descarga do Rio Paraná e a OS.

Por outro lado, a Lagoa dos Patos recebe afluentes que drenam uma área de aproximadamente $201.700 \mathrm{~km}^{2}$ (Vieira \& Rangel, 1988), que seguem um ritmo de escoamento típico daqueles de médias latitudes: alta descarga no fim de inverno e início de primavera, seguida de uma baixa a moderada descarga durante verão e outono. Nesta estrutura sazonal geral há grandes variações interanuais (Möller, 1996).

A média mensal de descarga dos diversos rios deste sistema é da ordem de $2.400 \mathrm{~m}^{3} \mathrm{~s}^{-1}$, com fortes vari ações sazonais e com pico de descarga no inverno. Variações interanuais são observadas e diferenças significativas são encontradas em períodos de "El Niño". A correlação da vazão total dos rios da bacia da Lagoa dos Patos com a OS é altamente significativa (Vaz et al., no prelo).

\subsection{Resultados de Simulações Numéricas}

Estudos realizados por Soares (2003) e Pimenta (2001) utilizam não somente a descarga fluvial como forçante da circulação, mas também o vento e as marés.

Segundo Pimenta (2001), que não levou em conta a descarga da Lagoa dos Patos em seus experimentos, o alcance da pluma do Rio da Prata ao longo da costa mostrou-se diretamente relacionado à descarga fluvial e, sob situações de média descarga, uma banda costeira de 
baixa salinidade é formada desde o estuário até a costa sul do Brasil (aproximadamente $30^{\circ} \mathrm{S}$ ). Também apontou que a pluma estuarina determina um fluxo costeiro de sentido nordeste da ordem de poucos centímetros por segundos, que é persistente sobre a plataforma uruguaia e gaúcha, e proporcional à magnitude da descarga fluvial.

Soares (2003) em seus experimentos numéricos deu maior ênfase à interação entre as plumas do Rio da Prata e da Lagoa dos Patos. Estas mostraram que as correntes induzidas pelo Rio são compostas por seus modos barotrópicos e baroclínicos. As correntes barotrópicas foram iniciadas pela rápida passagem de ondas externas de Kelvin, conforme as correntes baroclínicas foram iniciadas pelas ondas internas de Kelvin, cujas velocidades de fase são muito menores. Como resultado, correntes barotrópicas fluindo em direção ao norte foram criadas na PCGU apenas aguns dias depois que a pluma do La Plata foi iniciada, e a influência das correntes induzidas pelo La Plata na pluma da Lagoa dos Patos iníciou-se muito antes do dia que a pluma do Rio da Prata realmente alcançou a PCGU. O tempo necessário para a ponta da pluma do Rio da Prata chegar a PCGU variou de acordo com a descarga do Rio. Para a descarga anual média de $32000 \mathrm{~m}^{3} \mathrm{~s}^{-1}$ foram necessários 105 dias, e para $22000 \mathrm{~m}^{3} \mathrm{~s}^{-1}$ médios, 140 dias.

A pluma da Lagoa dos Patos aparenta ter uma participação menor mas importante na dinâmica da PCGU. Basicamente sua contribuição tem dois efeitos: um relacionado ao transporte da água da pluma do Rio da Prata, que é menor na simulação onde ambas são consideradas do que naquela em que a pluma do Rio da Prata foi simulada na ausência da Lagoa dos Patos.

O outro efeito é a formação de uma zona de convergência em direção ao sul da desembocadura da Lagoa, que é importante para a ecologia local. Este efeito ocorre devido à interação entre as correntes induzidas pelas plumas. As correntes próximas da costa, que ocorrem na metade sul da pluma da Lagoa dos Patos, são direcionadas ao sul, porque ocorre inicialmente expansão da pluma para o sul e depois um giro para o norte, com a pluma fluindo então em direção ao equador, seguindo a fase da direção de propagação da onda de Kelvin. Estas correntes fluindo para o sul encontram as correntes fluindo para o norte na ponta da pluma do La Plata, formando uma área de convergência na zona próxima a costa, que favorece a acumulação de nutrientes, plâncton, incluindo ovos e larvas de peixes (Soares, 2003).

O efeito anterior (pequena intrusão para o norte da água do Rio da Prata na presença da pluma da Lagoa dos Patos) ocorre principalmente porque a pluma da Lagoa age como uma barreira das correntes que fluem para o norte, induzidas pela descarga do Rio da Prata, especialmente na zona mais próxima à costa. Mas também ocorre devido à água de baixa salinidade proveniente da Lagoa dos Patos ser fracamente estratificada, reduzindo a estratificação e a intensidade de velocidades baroclinicas na ponta da pluma do Rio da Prata, resultando numa intrusão reduzida para o norte. Isto indica que não somente a descarga do Rio da Prata é capaz de mudar a circulação da pluma da Lagoa dos Patos mas também que o oposto também é verdadeiro (Soares, 2003).

Considerando todas as forçantes, Soares (op cit.) conclui que o Rio da Prata é importante na dinâmica da PCGU e sua influência mostra mudanças significativas sazonais devido à variações na tensão e direção do vento. A influência das águas do Rio da Prata na PCGU é mais forte quando ventos que causam subsidência são dominantes e mais fracos quando 
ventos de ressurgência são mais frequentes, o que usualmente ocorre durante os períodos de outono/inverno e de primavera/verão, respectivamente.

Entretanto, o Rio da Prata não é capaz de sozinho criar os padrões de circulação observados na área de estudo. A presença da descarga da Lagoa dos Patos obstrui as correntes associadas a pluma do Rio da Prata que fluem para o norte, resultando numa área estagnada entre as duas plumas. A água fluvial se acumula nesta área, formando uma extensa banda de baixa salinidade, que interage com correntes fora da costa. Variações sazonais significativas são esperadas devido à interação das correntes do Brasil e das Malvinas, com fortes intrusões de água do Rio da Prata para o norte ocorrendo durante o inverno e outono, quando a Corrente das Malvinas é mais intensa.

\subsection{Influência da Circulação no transporte e retenção do Ictioplâncton na PCAS}

O cenário oceanográfico do sul do Brasil proporciona condições ambientais ideais para assegurar retenção de larvas através da combinação de fatores como o Transporte de Ekman direcionado para a costa no inverno e primeira metade da primavera, das frentes termohalinas sobre a plataforma externa e talude (Lima \& Castello, 1995; Bakun, 1996; Piola et al., 2000; Busoli, 2001) e do derrame das águas pluviais do Rio da Prata e Lagoa dos Patos sobre a plataforma, contribuindo para a formação de uma coluna de água com estabilidade vertical e maior produção biológica (Ciotti et al., 1995).

Busoli (2001) realizou um estudo analizando o ictioplâncton durante o inverno e primavera, focando a distribuição espacial bidimensional de ovos e larvas de Engraulis anchoita e suas relações com o padrão de circulação geostrófica para a região. As maiores concentrações ocorreram no inverno, em bandas ao longo da costa, que parecem curvar ao redor de uma zona de baixa concentração localizada na desembocadura da Lagoa dos Patos. Os fluxos de ovos e larvas tendem a apresentar giros anticiclônicos ao redor desta zona.

O autor também analisou a concentração de larvas classificadas em 5 classes de tamanho, a saber: A) menores que $4 \mathrm{~mm}$; B) entre 4 e $8 \mathrm{~mm}$; C) entre 8 e $12 \mathrm{~mm}$; D) entre 12 e $16 \mathrm{~mm}$ e E) entre 16 e $20 \mathrm{~mm}$. Tanto no verão como na primavera, o padrão de distribuição encontrado foi semelhante, larvas menores mostraram maiores concentrações ao sul do domínio e larvas maiores apresentaram maior abundância ao norte. Apesar da abundância ser maior no inverno, na primavera houve uma predominância de larvas de maior tamanho (acima de 12 $m m$ ), sugerindo uma eficiente retenção e menor mortalidade.

Com os resultados obtidos, o autor sugere que um maior deságue continental transformou a PCSB em uma importante zona de retenção de larvas de peixes, sendo visualisadas células de re-circulação nas regiões centrais da PCSB.

Sanchez \& Ciechomski (1995) concluíram em seu trabalho que cada ecossistema que analizaram (entre $34^{\circ} \mathrm{S}$ e $55^{\circ} \mathrm{S}$ ) apresenta ao menos uma feição física de meso-escala que assegura a retenção dos estágios iniciais de desenvolvimento da anchoíta. Segundo os autores, parte das larvas nascidas durante o outono e inverno são advectadas para norte, onde irão se desenvolver em águas mais quentes. Por outro lado, larvas nascidas na primavera e ínício do verão próximos a província de Buenos Aires irão ser retidas nesta área. 
Soares (2003), comparando dados obtidos de suas simulações numéricas com a distribuição zooplanctônica da área, sugere que os padrões encontrados na primavera estão de acordo com os padrões de circulação obtidos para a área. Neste há a dominância de eventos de ventos de nordeste que causa ressurgência em todo o domínio, o que favorece "blooms" planctônicos. As velocidades fora da costa na camada de superfície transportam esse bloom para o oceano aberto. Além disso as correntes residuais tendem a apresentar valores significantes na proximidade da costa, direcionadas ao sul, que são responsáveis pela distribuição dos "blooms" planctônicos ao longo da costa.

Por outro lado, durante o outono as correntes residuais mostram uma zona de baixa dinâmica ocorrendo fora das costas, entre o Albardão e o Uruguai, que é favorável a acumulação de plâncton e nutrientes. Esta zona de convergência aparece tanto na circulação residual dirigida pela flutuação como na dirigida pelo vento. Essa circulação aumenta o tempo de residência de ovos e larvas nesta região e a sua localização é coincidente com a localização das maiores concentrações de ovos encontradas por Busoli (2001). 


\section{Capítulo 3}

\section{A anchoíta Engraulis anchoita}

Uma das espécies mais abundantes na região é Engraulis anchoita (Figura 3.1), um pequeno peixe pelágico que habita não somente a PCGU mas uma larga área na plataforma continental da América do Sul, entre as latitudes $23^{\circ} \mathrm{S}$ e $47^{\circ} \mathrm{S}$, cuja desova ocorre ao longo de todo o ano, em diferentes localidades (Lima \& Castello, 1995). Dentro de sua extensa área de distribuição sobre a Plataforma Continental da América do Sul são registradas biomassas da ordem de 4 milhões de toneladas em águas argentinas e uruguaias (Ciechomski \& Sanchez, 1988) e superiores a um milhão de toneladas no extremo sul do Brasil (Lima \& Castello, 1995).

Nesta área não há exploração comercial desta espécie, com excessão de pequenas capturas (abaixo de 30000 tano $^{-1}$ ) pela frota Argentina. Por esta razão, a anchoíta se mostra como um recurso alternativo frente ao atual estado de colapso ou sobrexplotação da maioria das pescarias tradicionais da região, principalmente por ser uma excelente matéria prima para a indústria de conservas. Mas, sua importância vai além deste potencial para a indústria pesqueira, pois a anchoíta ocupa uma importante posição no ecossistema pelágico, predominando na dieta de diversas espécies de peixes de interesse comercial, como pescada, merluza, cavala e peixe espada. Se estima que aproximadamente $1.600 .000 t$ de anchoíta são consumidas por ano pela merluza e $171.000 t$ por pinguins (Ciechomski \& Sanchez, 1988; Vasconcelos, 1994; Lima \& Castello, 1995; Sanchez \& Ciechomski, 1995).

A anchoíta apresenta três áreas como locais de desova na Plataforma Continental Sudoeste da América do Sul, onde a combinação de distintos processos oceanográficos originam habitats adequados à sobrevivência das larvas: a bacia do sudeste brasileiro; o extremo sul do Brasil, Uruguai e costa bonariense e a Plataforma Continental Central Patagônica (Bakun, 1993). Estudos realizados com estoques dosovantes e coleta de ovos e larvas no plâncton mostram que a anchoíta apresenta uma atividade reprodutiva ao longo de todo o ano nesta região, com alguns picos bem definidos (Sanchez \& Ciechomski, 1995; Castello, 1997). O pico de atividade reprodutiva na PCGU é a primavera e inverno, onde grandes concentrações de adultos em atividade de desova e de ovos e larvas foram detectadas (Melo, 1978; Weiss \& Souza, 1977; Hubold, 1982; Castello, 1995). Na PCAU, também é nos meses de primavera que ocorre a maior extensão da área de desova e os maiores valores de produção diária de ovos (Sanchez \& Ciemchomski, 1995). A desova parece estar condicionada por um ambiente ótimo para a alimentação e crescimento das larvas (Bakun \& Parrish, 1991), como trans- 


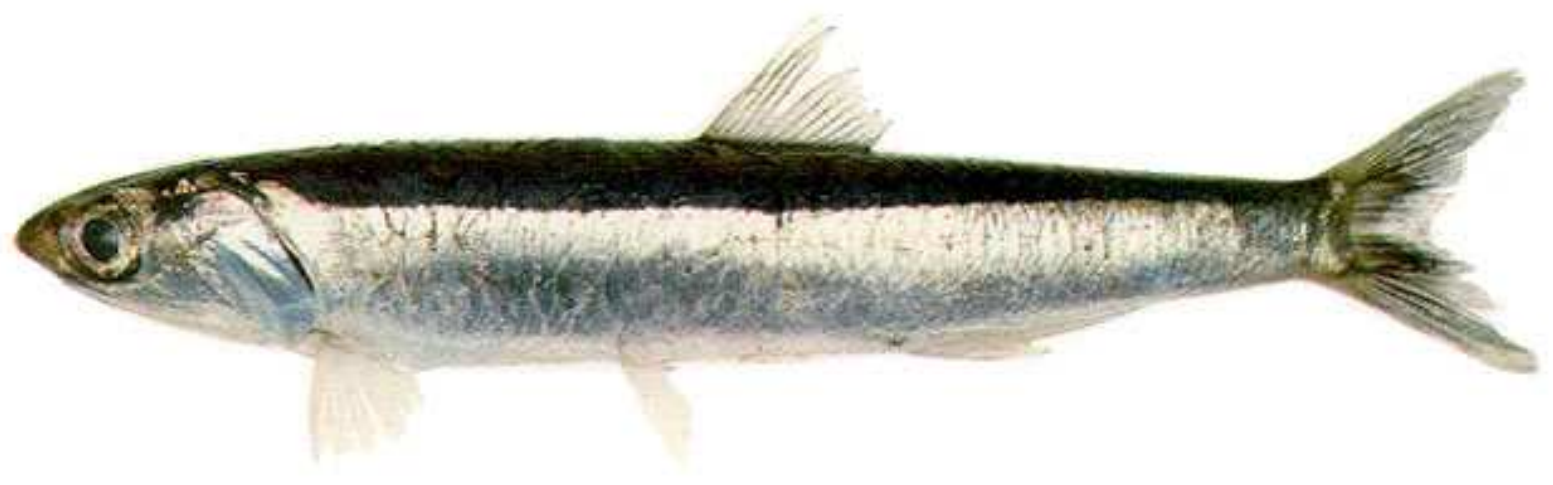

Figura 3.1: Anchoíta Engraulis anchoita (Cousseau \& Perrotta, 1998)

porte de Ekman direcionado para a costa (Lima \& Castello, 1995) e o deságue continental que favorece a produção primária (Ciotti et al., 1995).

Lima \& Castello (1994) investigaram a distribuição da anchoíta pela costa sul do Brasil através de dados acústicos e de pesca experimental obtidos em sete campanhas oceanográficas e as maiores concentrações de anchoitas adultas encontradas estavam na plataforma continental entre os 20 e 100 metros de profundidade. Sanchez \& Ciechomski (1989) analizando uma série histórica de dados (1966-1988) verificaram que, embora alguma desova ocorra até a $400 \mathrm{~km}$ de distância da costa, a maior parte da desova (95\%) ocorre até $150 \mathrm{~km}$ da costa, em profundidades menores que 75 metros.

A eclosão dos ovos ocorre em função da temperatura, pela seguinte relação obtida por Ciechomski \& Sanchez (1984):

$$
\log Y=2,449-0,042 X
$$

Onde:

$\mathrm{Y}=$ Idade à eclosão (horas)

$\mathrm{X}=$ Temperatura à ${ }^{\circ} \mathrm{C}$

O tamanho médio das larvas no momento da eclosão é de $2.7 \mathrm{~mm}$ (Castello, 1997, Ekau, 1998) e o a relação de crescimento é dada por (Ekau, 1998):

$$
L t=(2,718) \exp 3,102[1-\exp (-0,041 t)]
$$

Onde:

Lt: comprimento da larva ao tempo $t$

t: tempo em dias

Phonlor (1984) realizou um estudo da morfologia e biologia das larvas de Engraulis anchoita no sul do Brasil e verificou que entre 7 e $12 \mathrm{~mm}$ as larvas passam por transformações 
significativas em sua estrutura, envolvendo desde o desenvolvimento das nadadeiras até o surgimento da vesícula gasosa. Estas transformações podem ser observadas na figura 3.2, na qual está representado o crescimento larval para a espécie.

Vasconcellos (1994) analisou a distribuição, o crescimento e a mortalidade das larvas de anchoíta sobre a Plataforma Continental Sul do Brasil, com ênfase da influência dos processos biológicos-oceanográficos na sobrevivência das larvas. Ele observou que a anchoíta usa a PCGU como área de desova e desenvolvimento larval, vinculando-os à ressurgências costeiras e a áreas influenciadas pela Convergência Subtropical. O autor registrou que as maiores densidades de larvas são encontradas ao sul de Rio Grande, especialmente durante o inverno e a primavera, sendo esta distribuição influênciada pela magnitude do aporte continental, pela intensidade da penetração das águas mais frias e pela abundância do estoque parental, os quais determinam a extensão geográfica da área de desenvolvimento e o padrão de ocupação e dispersão das larvas sobre a plataforma continental. A fase mais crítica para as larvas seria entre a primeira alimentação e aproximadamente os $10 \mathrm{~mm}$, em que a capacidade de locomoção é bastante limitada. Nesta fase o crescimento e a mortalidade estão fortemente dependentes do encontro com concentrações adequadas de alimento formadas, em princípio, durante condições de estabilidade da coluna d'água. Larvas mais desenvolvidas apresentam taxas de mortalidade sem relação com as condições de estabilidade vertical.

Analisando a variação do grau de contágio das larvas de anchoíta com o seu desenvolvimento, Vasconcellos ( $o p$ cit.) encontrou duas fases distintas no padrão de distribuição. As larvas entre sua eclosão e até alcaçarem o tamanho de $8,5 \mathrm{~mm}$ sofrem muita dispersão, a qual é o resultado de processos físicos como ventos e correntes, agindo sobre larvas originalmente agrupadas como resultado da maior concentração de adultos no momento da desova. Após atingirem o tamanho de $10 \mathrm{~mm}$, o índice de contágio aumenta, mostrando uma retomada da distribuição agrupada, a qual está relacionada com o aumento da habilidade e da capacidade de locomoção das larvas.

A anchoíta foi escolhida para ser utilizada neste trabalho pois a ecologia desta espécie e os padrões de distribuição de seus ovos e larvas na PCGU e PCAU são as mais conhecidas dentre as espécies habitantes da região (Sanchez, 1986; Ciechom ski \& Sanchez, 1988; Bakun \& Parrish, 1991; Vasconcellos, 1994; Lima \& Castello, 1995; Matsuura \& Kitahara, 1995; Muelbert \& Sinque, 1995; Sanchez \& Ciechomski, 1995; Ekau, 1998; Busoli, 2001) e servirá de modelo para o que ocorre no transporte e retenção de ictionplâncton na área. Além disso o conhecimento dos padrões de transporte e retenção larval da Engraulis anchoita, torna-se fundamental para melhorar o conhecimento do sistema, dada a sua importância no ecossistema como espécie forrageira, e também pelo fato de que seu estoque apresenta grande potencialidade pesqueira, podendo ser necessário um controle de sua captura num futuro próximo. 

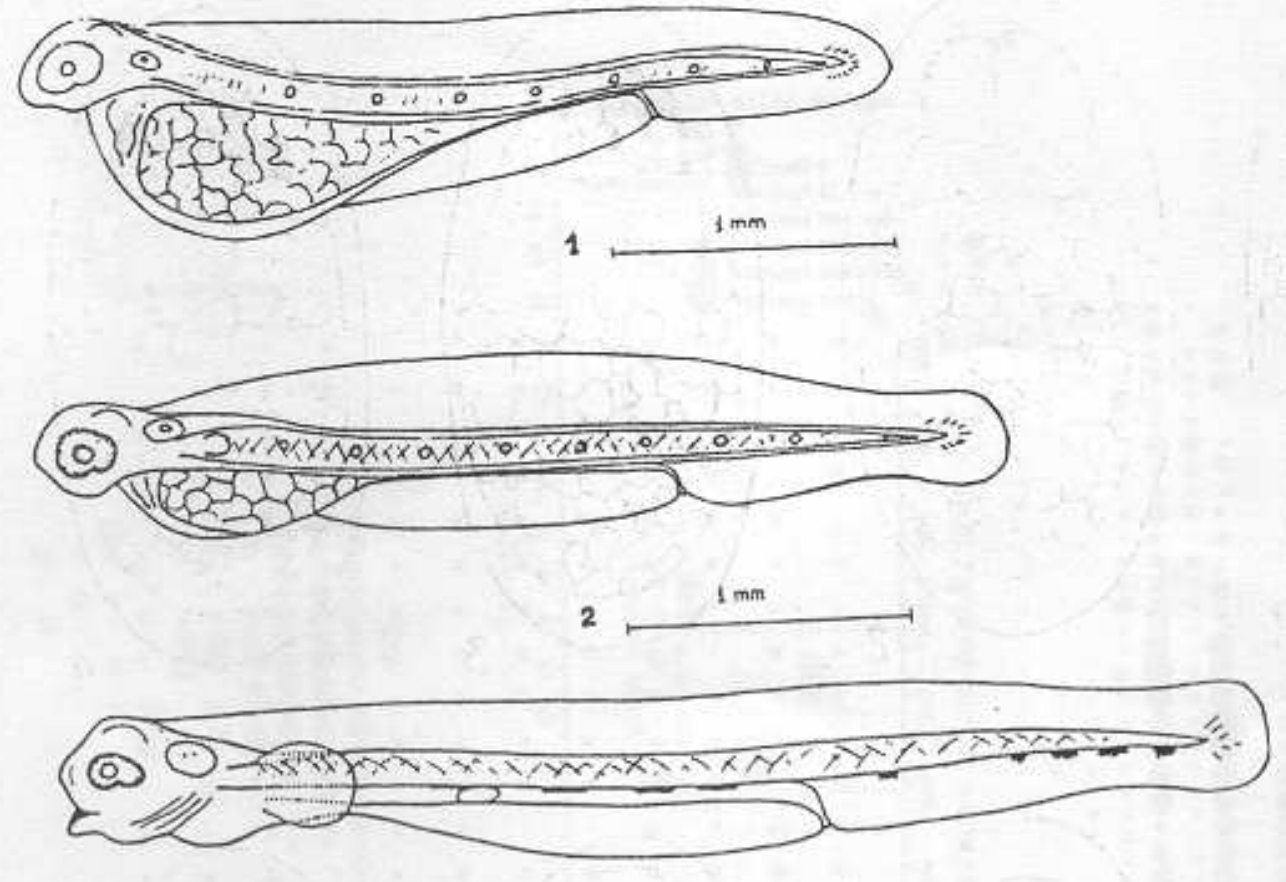

3
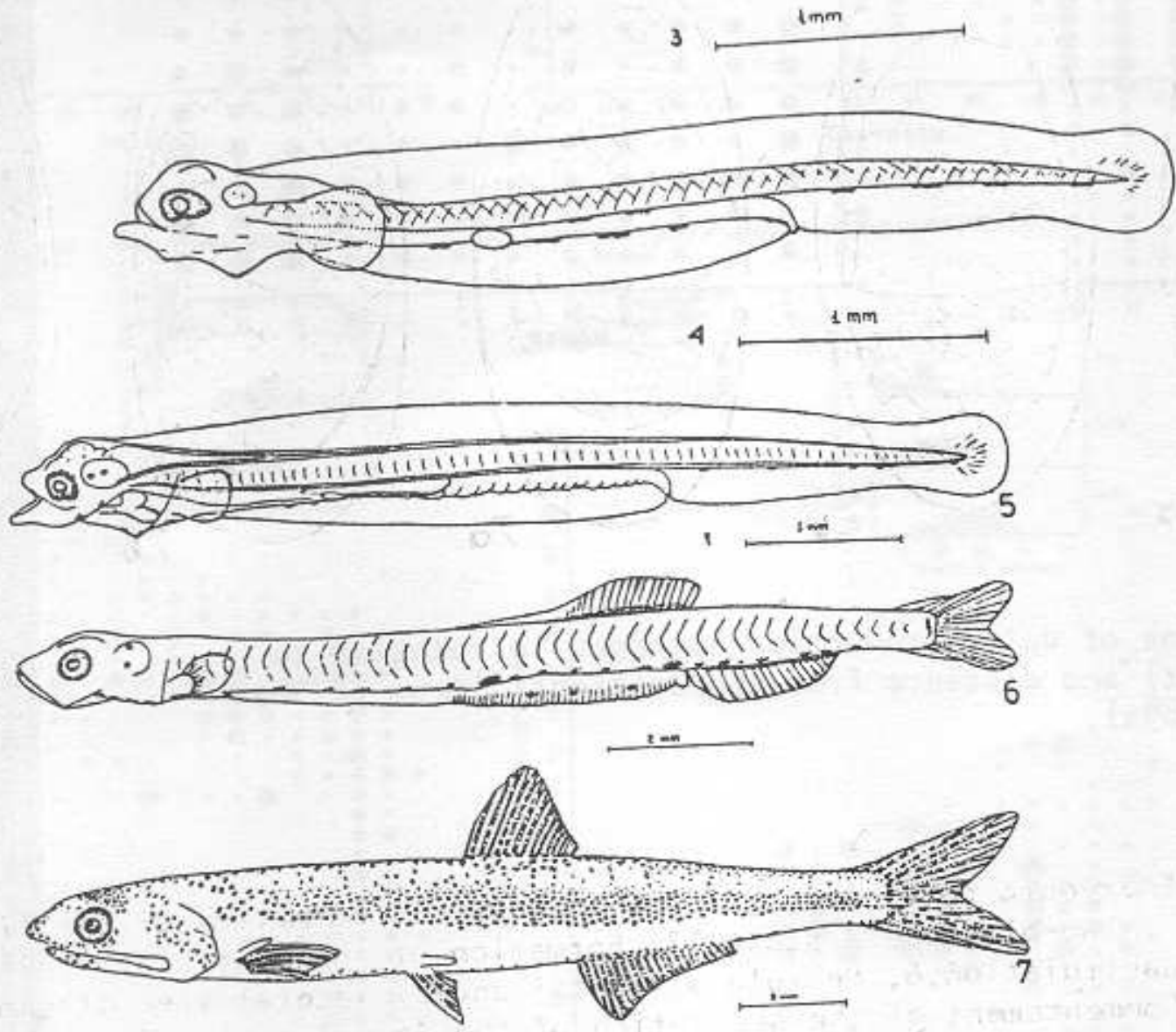

Figura 3.2: Desenvolvimento larval da anchoíta (Ciechomski, 1965 apud Sanchez, 1989). 1) Larva récem eclodida 2) Larva de 2-5 dias 3) Larva de 3-4 dias 4) Larva de 10 dias 5) Larva de $6 \mathrm{~mm} 6$ ) Larva de $13.5 \mathrm{~mm}$ 7) Juvenil de $44 \mathrm{~mm}$ 


\section{Capítulo 4}

\section{Materiais e Métodos}

\subsection{Modelagem baseada no indivíduo}

O estudo do recrutamento de peixes pelágicos é um problema altamente complexo, e a busca de alternativas para sua resolução aumentou a necessidade da criação de novas técnicas que explorem os processos ecológicos envolvidos.

Nos estudos de populações de peixes, diversos trabalhos vêm fazendo uso de modelos hidrodinâmicos acoplados a modelos biológicos, sendo que na modelagem tradicional do plâncton, a maneira mais comum de representar as fases iniciais dos peixes é considerar ovos e larvas como partículas passivas confrontadas por condições ambientais provenientes de saídas de modelos hidrodinâmicos.

Uma maneira relativamente nova de tratar o problema é utilizar os chamados "modelos baseados no indivíduo" (individual based model, ou IBM). Este tipo de ferramenta vem sendo amplamente utilizada em modelagem ecológica, especialmente a partir da última década (Grimm, 1999). "Modelagem baseada no indivíduo" é aquela que trata indivíduos como entidades únicas e discretas, com atributos próprios que mudam durante o seu ciclo de vida, como tamanho, posição, peso etc.

Os IBMs surgem ao se adicionar propriedades biológicas às partículas, criando indivíduos. Estes modelos permitem a representação espacial e a integração de dados ambientais, ecológicos e biológicos (Letcher et al., 1996; Grimm, 1999; Huggett, 2003).

Este tipo de modelagem vem ganhando cada vez mais notoriedade em diversos campos de modelagem ecológica, desde que Huston et al. (1988) publicaram uma revisão que delineou a modelagem baseada no indivíduo, anteriormente usada esporadicamente, como uma abordagem explicitamente delineada dentro da modelagem ecológica.

Até então, o que existiam eram modelos de variáveis estáticas, baseados nos modelos clássicos de população, que são aqueles nos quais todos os membros de uma população são representados em variáveis estáticas simples, como tamanho da população, biomassa, captura. Desta forma, a unicidade do indivíduo é retirada, é assumido que todos os organismos são idênticos, que não há perda de informação por considerar apenas médias da população e, além disso, é retirada a dependência espacial, assumindo que cada organismo exerce a mesma influência em todos os outros, independente de sua localização no sistema (Lomnicki, 
1992).

As principais vantagens de usar a abordagem baseada no indivíduo são que modelos de variáveis estáticas não consideram importantes características dos indivíduos, como sua variabilidade individual, e a teoria que emerge de abordagens de variáveis estáticas apresentam severas deficiências. Segundo Grimm (1999) a primeira motivação pode ser referida como 'pragmática', porque enfatiza a idéia pragmática que os IBMs simplesmente adicionam uma nova ferramenta na modelagem ecológica, enquanto a segunda pode ser referida como 'paradigmática', porque enfatiza a atitude de que algo está errado com os paradigmas da teoria clássica da ecologia de população.

DeAngelis \& Gross (1992), citam outras vantagens trazidas por este tipo de modelagem: uma grande variedade de tipos de diferenças entre indivíduos na população podem ser acomodados; decisões complexas feitas por indivíduos podem ser simuladas; interações locais no espaço e efeitos de variabilidade estocástica espacial e temporal são facilmente manejadas; e uma ampla variedade de escalas temporais e espaciais podem ser integradas no processo de modelagem.

Apesar das indiscutíveis vantagens, estes modelos também apresentam algumas restrições. As primeiras limitações para a modelagem são a disponibilidade de recursos computacionais adequados ao problema que se deseja tratar e a existência de teorias ecológicas que embasam as suposições adotadas para as interações dos indivíduos no sistema. Também é necessário a disponibilidade de dados coletados no ambiente para a validação do modelo. Outras restrições podem ser consideradas "armadilhas": a primeira é que a complexidade dos modelos podem fazer com que se perca a habilidade de discriminar processos, entre a variedade de detalhes e de mecanismos que interagem. Outra é que a realização de testes com o modelo podem ser tão complexos que essencialmente qualquer observação pode ser acomodada simplesmente alterando os parâmetros (Murdoch et al., 1992)

Por estes "perigos", alguns cuidados devem ser tomados durante o processo de elaboração e implementação do modelo. A partir de resultados obtidos em 10 anos de modelagem baseada no indivíduo, Grimm (1999), faz uma revisão sobre o tema e levanta algumas regras a respeito da filosofia da modelagem baseada no indivíduo em Ecologia, as quais buscou-se respeitar no desenvolvimento deste trabalho, e que estão listadas a seguir:

1) Modelagem baseada no indivíduo é Modelagem

2) Os modelos devem ser mantidos o mais simples possível

3) A finalidade mais importante da modelagem é o entendimento

4) Modeladores devem adotar a atitude de experimentadores

5) Começar a modelar com padrões que podem ser observados na natureza

\subsection{Descrição do Modelo Biológico}

O modelo utilizado foi desenvolvido como parte dos objetivos deste trabalho e trata-se de uma ferramenta de uso inédito na oceanografia brasileira. Este modelo acompanha a trajetória de ovos e larvas de anchoíta, desde a sua desova até alcançarem o estágio pós-flexão (10 $\mathrm{mm}$ ). Outros processos como eclosão, crescimento, mortalidade também são simulados.

O modelo recebe como entrada os campos superficiais de velocidade, proveniente de 


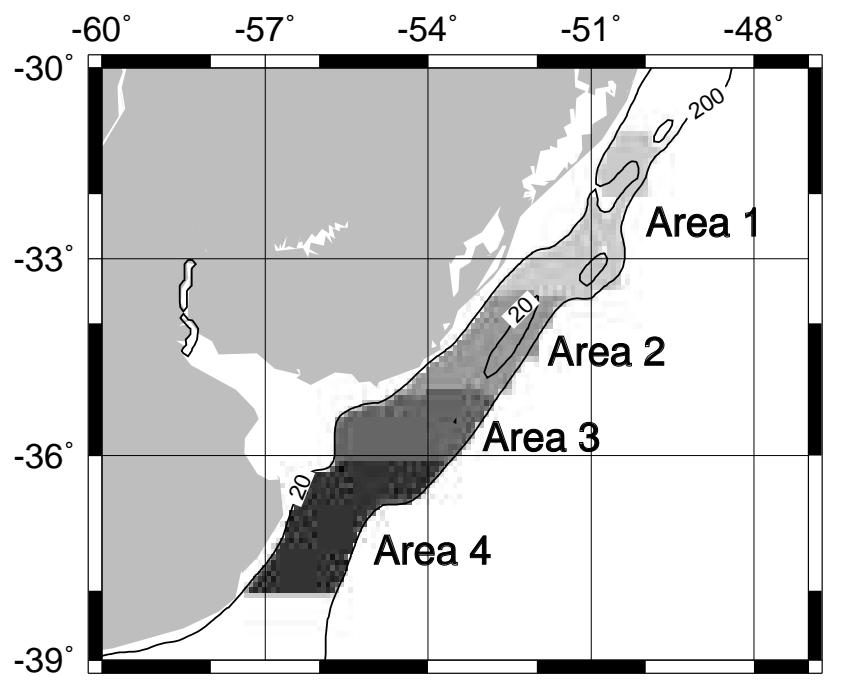

Figura 4.1: Áreas de desove, localizadas entre as isóbatas de 20 a 200 metros. Área 1, Costa Riograndina $31^{\circ} \mathrm{S}$ a $33,5^{\circ} \mathrm{S}$. Área 2 , Costa Uruguaia - 33,5 $\mathrm{S}$ a $35^{\circ} \mathrm{S}$. Área 3 , Região do Rio da Prata - $35^{\circ} \mathrm{S}-36^{\circ} \mathrm{S}$. Área 4 , Costa Bonairense - $36^{\circ} \mathrm{S}-38^{\circ} \mathrm{S}$

qualquer modelo hidrodinânico. Foram consideradas somente as velocidades superficiais, dado que os estágios larvais que interessam ser observados, larvas pré-flexão e flexão, são mais abundantes na camada de mistura, de 10 a 50 metros de profundidade (Matsuura \& Kitahara, 1995). Desta forma, a velocidade da camada de mistura foi considerada homogênea e aproximada à velocidade superficial.

A área de desova da anchoíta neste trabalho foi considerada como sendo a área contida na plataforma continental que se extende $31^{\circ} \mathrm{S}$ a $38^{\circ} \mathrm{S}$, entre as isóbatas de 20 a 200 metros. Esta área foi dividida em 4 subáreas, a saber:

- 1) Costa Riograndina $-31^{\circ} \mathrm{S}$ a $33,5^{\circ} \mathrm{S}$

- 2) Costa Uruguaia - $33,5^{\circ} \mathrm{S}$ a $35^{\circ} \mathrm{S}$

- 3) Região do Rio da Prata $-35^{\circ} \mathrm{S}-36^{\circ} \mathrm{S}$

- 4) Costa Bonairense - $36^{\circ} \mathrm{S}-38^{\circ} \mathrm{S}$

A divisão, exibida na figura 4.1, levou em conta tanto feições oceanográficas da região, como o comportamento de desova da anchoíta nessas áreas. A desova da anchoíta apresenta variações sazonais entre as regiões (Sanchez \& Ciechomski, 1995; Castello, 1997). Durante o inverno são observadas grandes concentrações de adultos desovantes e de ovos e larvas nas áreas de 1 a 3 . No mês de outubro, é provável que ocorra desova significativa nas 4 áreas e em novembro e maio especialmente na área 4 (Weiss \& Souza, 1977; Hubold, 1982; Castello, 1995; Sanchez \& Ciechomski, 1995). Além das épocas de desova variarem entre essas regiões, trabalhos realizados na região apontaram o comportamento de áreas específicas como centros de retenção larval. Soares (2003), levantou a importância da zona com correntes residuais fracas localizada na costa uruguaia e sul brasileira na retenção do ictioplâncton. Busoli (2001), apontou os giros formados pela descarga de água doce da Lagoa dos Patos na 
plataforma continental brasileira como um eficiente mecanismo de retenção larval. Sanchez \& Ciechomski (1995), mostraram que o comportamento da costa bonairense como área de retenção varia ao longo do ano. Desta forma, essa divisão foi feita para ser possível observar o comportamento de cada região, bem como as diferenças existentes entre elas, como qual apresenta maior retenção, maior transporte, verificar as diferenças sazonais no melhor ou pior desempenho da retenção e saber a procedência das larvas retidas em cada área.

O lançamento das partículas no momento da desova é feito randomicamente, e todas são consideradas com o mesmo tamanho. A eclosão acontece como função da temperatura, pela relação de Ciechomski \& Sanchez (1984) descrita no Capítulo 3. A temperatura superficial utilizada para o cálculo do tempo de eclosão foi baseada nos resultados obtidos por Piola et al. (2000), no qual os autores calcularam para o inverno e o verão, as temperaturas superficiais médias para cada grau de latitude da plataforma continental localizada entre $39,5^{\circ} \mathrm{S}$ e $25^{\circ} \mathrm{S}$. A partir destes dados foi gerada uma média de temperatura superficial para a área de desova, a qual resultou em $22,08^{\circ} \mathrm{C}$ no verão e $13,21^{\circ} \mathrm{C}$ no inverno, gerando tempos de eclosão de 1,37 e 3,23 dias, respectivamente. O resultado de verão foi aproximado para 1,5 dias e utilizado também na primavera e o de inverno para 3 dias e utilizado também no outono.

O tamanho das larvas no momento da eclosão é considerado uniforme, em 2,718 $\mathrm{mm}$ e o crescimento calculado pela relação de Ekau (1998), também apresentada no Capítulo 3.

As larvas são acompanhadas durante a fase mais crítica de seu desenvolvimento, onde são partículas passivas sem capacidade de locomoção e são transportadas pelas correntes. Esta fase se extende até atingirem o tamanho de $10 \mathrm{~mm}$, quando adquirem a capacidade de natação ativa e podem se manter em áreas adequadas ao seu desenvolvimento, chamadas daqui para frente de "áreas berçário". Quando as larvas atingem este tamanho suas posições são salvas, elas são retiradas do modelo e então é realizado uma nova desova.

Foi considerado que a área berçário se extende pela plataforma continental, entre as isóbatas de 20 e $350 \mathrm{~m}$ e entre $31^{\circ} \mathrm{S}$ a $38^{\circ} \mathrm{S}$ de latitude, apresentando a mesma divisão em subáreas utilizada para a desova. Elas foram definidas com base nos trabalhos de distribuição de ovos e larvas, os quais mostram que a maior concentração desses organismos está nessa região (Vasconcellos, 1994; Muelbert \& Sinque, 1995; Sanchez \& Ciechomski, 1995; Lima \& Castello, 1997). Pelo fato das isóbatas de 350 e $200 \mathrm{~m}$ estarem muito próximas nesta área, se optou por extender a área berçário a $350 \mathrm{~m}$, embora alguns trabalhos se limitem a coletas na isóbata dos $200 \mathrm{~m}$. É considerado que o sucesso na retenção ocorre quando larvas de $10 \mathrm{~mm}$ estão situadas numa área berçário, onde podem dar sequência ao seu desenvolvimento. O número de larvas retidas é então dado pela soma das larvas que tiveram sucesso na retenção.

A batimetria utilizada para a delimitação das regiões de desova e retenção é a mesma usada por Palma et al. (2004) e descrita na subseção 4.4.2.

O método de integração espacial usado no cálculo do deslocamento das partículas foi o de Runge-Kutta de quarta ordem.

Foram adotadas como condições de contorno para o modelo a terra e os limites da área. Ao atingirem estas regiões as larvas são consideradas mortas, contabilizadas e retiradas do modelo, sendo o passo de tempo utilizado de 12 horas.

Como a trajetória dos ovos e larvas também depende de um campo turbulento, foi realizada uma combinação do campo de velocidade com o campo turbulento para simular di- 
fusão. O método utilizado para representar o campo de velocidade turbulenta superimposto ao campo de velocidades determinísticas pertence a uma classe de modelos chamada de "random flight" (van Dop et al 1985, Thompson, 1987).

O movimento das partículas na presença de uma velocidade turbulenta $\mathbf{u}$, com componentes $u$ e $v$ superimpostas no jato meandrante, pode ser descrito como:

$$
\begin{aligned}
& \frac{d x}{d t}=U+u \\
& \frac{d y}{d t}=V+v
\end{aligned}
$$

A velocidade turbulenta $\mathbf{u}$ é característica de movimentos complexos e incoerentes, que ocorrem em escalas menores que as escalas da corrente e é descrita em termos estatísticos, em contraste com a velocidade determinística de larga escala U. Neste trabalho iremos utilizar o tipo mais simples de estatística de partículas, descrevendo o movimento de partículas simples e independentes no fluxo.

A velocidade turbulenta $\mathbf{u}$ nas equações 4.1 e 4.2 pode ser descrita seguindo o método "random flight", isto é, como um processo puramente dependente do tempo, representando o campo de velocidade turbulenta como amostrado pela partícula durante seu movimento. No modelo é considerado o caso simples de um campo turbulento unidimensional, homogêneo e estacionário, sem cisalhamento médio, onde a velocidade turbulenta é descrita pela equação de Langevin (1908):

$$
d u=(-u F d t)+d \mu
$$

e $x(t)$ é dado por:

$$
d x=u d t
$$

Onde:

$F=1 / T_{L}$ : inverso da constante de escala de tempo $T_{L}$ sobre a qual a velocidade da partícula é correlacionada

$d \mu$ : incremento randômico de uma distribuição normal com média zero e momento de segunda ordem $\langle d \mu \cdot d \mu\rangle=\left(2 \sigma / T_{L}\right) d t$

$\sigma$ : variância da velocidade turbulenta

A equação 4.3 descreve um processo Markoviano, onde a velocidade por passo de tempo depende linearmente da velocidade no passo de tempo anterior. Fisicamente ela indica que enquanto a partícula/organismo se move através da coluna d'água, ela recebe um impulso randômico $\mu$ devido a ação de um campo turbulento incoerente e perde uma fração do seu momento $d t / T_{L}$ para o fluido circundante (Dutkiewicz et al. 1993; Zambianchi \& Griffa 1994; Griffa, 1996; Cianelli et al., 2004).

A componente randômica dessa velocidade turbulenta é determinada a partir de um gerador de números randômicos gaussiano (de média 0, variância 1), descrito em Press et al. (1994). O valor utilizado para $T_{L}$ foi 2.5 dias e para $\sigma$ de $10^{-4} m^{2} s^{-2}$, segundo os valores apontados por Griffa (1996) como típicos. 


\subsection{Campos de velocidade}

Diversos trabalhos apontam a influência da dinâmica de Ekman no sucesso do recrutamento das larvas de anchoíta nesta área (Bakun \& Parrish, 1991; Lima \& Castello, 1995; Castello, 1997), com base em dados climatológicos e observacionais, mas estes trabalhos compõem apenas modelos conceituais e muitas vezes, envolvem um número limitado de dados para uma boa caracterização da relação circulação/recrutamento.

Desta forma, foram realizados dois experimentos distintos com o modelo de dispersão. No primeiro, o modelo foi alimentado com dados de velocidade superficial gerados apenas pela dinâmica de Ekman, o que simulou uma situação idealizada onde apenas o transporte gerado pela ação da tensão de cisalhamento do vento atuasse na dispersão dos organismos. No segundo, o modelo foi alimentado com um campo de velocidade superficial proveniente de um modelo hidrodinâmico, o qual foi rodado para toda a plataforma continental sul da América do Sul, e leva em conta, além da ação do vento, diversas forçantes como a entrada de água doce, a ação de marés, a Corrente do Brasil e a Corrente das Malvinas e a Confluência Brasil-Malvinas.

A seguir, é feita a descrição de como foram obtidos os dados da dinâmica de Ekman e do modelo hidrodinâmico utilizado para gerar os dados.

\subsubsection{Velocidade de Ekman}

Para a maioria das aplicações de larga escala temporal e espacial, o fluxo oceânico pode ser representado por apenas duas componentes: 1) correntes geostróficas que dominam a maior parte da coluna d'água; e, 2) transporte friccional de Ekman que ocorre próximo a superficie ou ao fundo. As equações do movimento podem, então, ser representadas pelo balanço entre os efeitos de Coriolis (primeiro termo), força pressão horizontal (segundo termo) e efeito friç̧ão vertical (terceiro termo):

$$
\begin{aligned}
& -f v=-\frac{1}{\rho} \frac{\partial p}{\partial x}+\frac{1}{\rho} \frac{\partial \tau_{x}}{\partial z} \\
& -f u=-\frac{1}{\rho} \frac{\partial p}{\partial y}+\frac{1}{\rho} \frac{\partial \tau_{y}}{\partial z}
\end{aligned}
$$

Estas equações podem ser separadas em duas componentes: velocidade geostrófica e velocidade de Ekman, isto é, $u \equiv u_{g}+u_{E}$ e $v \equiv v_{g}+v_{E}$. Substituindo esta definição nas equações 4.5 e 4.6, tem-se para a componente geostrófica:

$$
\begin{aligned}
& -f v_{g}=-\frac{1}{\rho} \frac{\partial p}{\partial x} \\
& -f u_{g}=-\frac{1}{\rho} \frac{\partial p}{\partial y}
\end{aligned}
$$

E para a componente de Ekman: 


$$
\begin{aligned}
& -f v_{E}=\frac{1}{\rho} \frac{\partial \tau_{x}}{\partial z} \\
& -f u_{E}=\frac{1}{\rho} \frac{\partial \tau_{y}}{\partial z}
\end{aligned}
$$

A espessura da camada de Ekman pode ser definida pela relação:

$$
\delta_{E}=\left(\frac{2 A_{v}}{f}\right)^{\frac{1}{2}}
$$

Onde $A_{v}$ representa o coeficiente cinemático de viscosidade turbulenta, cujo valor foi considerado como sendo de $10^{-1} \mathrm{~ms}^{-1}, \delta_{E}$ é a profundidade na qual o efeito do cisalhamento superficial se torna insignificante e $f$ é o pararâmetro de Coriolis, considerado $-8 \times 10^{-4}$ para a área de estudo.

Multiplicando ambos os lados das equações de Ekman (4.9 e 4.10) por $\rho$ e integrando de $\delta_{E}$ até a superfície, tem-se:

$$
\begin{aligned}
& -f \int_{-\delta_{E}}^{0} \rho v_{E} d z=\int_{-\delta_{E}}^{0} \frac{\partial \tau_{x}}{\partial z} d z \\
& -f \int_{-\delta_{E}}^{0} \rho u_{E} d z=\int_{-\delta_{E}}^{0} \frac{\partial \tau_{y}}{\partial z} d z
\end{aligned}
$$

Definindo as componentes do transporte de Ekman na superfície, $U_{E}$ e $V_{E}$ como o transporte total de massa envolvido no fluxo de Ekman, isto é, definindo:

$$
\begin{aligned}
& U_{E} \equiv \int_{-\delta_{E}}^{0} \rho u_{E} d z \\
& V_{E} \equiv \int_{-\delta_{E}}^{0} \rho v_{E} d z
\end{aligned}
$$

Multiplicando as equações 4.14 e 4.15 por $f$, substituindo as variáveis e realizando as intergrações, chega-se às equações clássicas do transporte de Ekman:

$$
\begin{gathered}
V_{E}=-\frac{\tau_{x}}{f} \\
U_{E}=\frac{\tau_{y}}{f}
\end{gathered}
$$

As velocidades da superfície da coluna d'água, podem ser então obtidas de 4.16 e 4.17 pelas seguintes relações:

$$
u_{e}=\frac{U_{E}}{\rho \delta_{E}}
$$




\begin{tabular}{cc}
\hline \hline Mês & Número de larvas \\
\hline Janeiro & 30000 \\
Fevereiro & 20000 \\
Março & 20000 \\
Abril & 20000 \\
Maio & 30000 \\
Junho & 20000 \\
Julho & 20000 \\
Agosto & 20000 \\
Setembro & 30000 \\
Outubro & 20000 \\
Novembro & 20000 \\
Dezembro & 10000 \\
\hline \hline
\end{tabular}

Tabela 4.1: Número de larvas de $10 \mathrm{~mm}$ contabilizadas por mês no experimento utilizando velocidade superficial de Ekman

$$
v_{e}=\frac{V_{E}}{\rho \delta_{E}}
$$

O campo de tensão de cisalhamento médio mensal utilizado para gerar as velocidades superficiais foi o mesmo que alimentou o modelo hidrodinâmico, obtidos do European Center for Medium-Range Forecast (ECMWF) e compilados por Trenberth et al. (1990). A grade utilizada tem resolução de 5' de grau. Os campos de velocidade média sazonal obtidos podem ser observadas na figura 4.2 .

Neste experimento, com velocidades superficiais geradas pela dinâmica de Ekman, o efeito da turbulência não foi considerado e a quantidade de larvas de $10 \mathrm{~mm}$ contabilizadas por mês pode ser observada na tabela 4.3.1. Convém salientar que estes números de larvas lançados são muito inferiores aos observados na natureza, já que concentrações maiores que 10000 ovos $10^{-1} \mathrm{~m}^{2}$ foram observadas em estudos de coletas in situ (Sanchez \& Ciechomski, 1995). Desta forma, estes valores são ilustrativos para as quantidades de larvas lançadas no modelo, que foram determinadas por limitações computacionais, e as devidas proporções com a realidade devem ser mantidas nas comparações a serem feitas.

\subsubsection{Modelo Hidrodinâmico}

O campo de velocidade superficial utilizado neste estudo foi obtido utilizando o modelo POM e uma descrição mais acurada dos experimentos realizados pode ser encontrada em Palma et al. (2004 a,b), Palma et al. (no prelo) e Palma et al. (in prep).

$\mathrm{O}$ domínio do modelo se extende de $55^{\circ} \mathrm{S}$ a $20^{\circ} \mathrm{S}$ e de $70^{\circ} \mathrm{W}$ a $40^{\circ} \mathrm{W}$. A grade horizontal curvilínea possui 250 pontos na posição ao longo da costa, que resulta numa resolução média de 7,5 km e 150 pontos de grade na dirção perpendicular a costa, com uma resolução média de $10 \mathrm{~km}$. Na vertical, as equações do modelo são discretizadas em 25 níveis sigma, com menor 

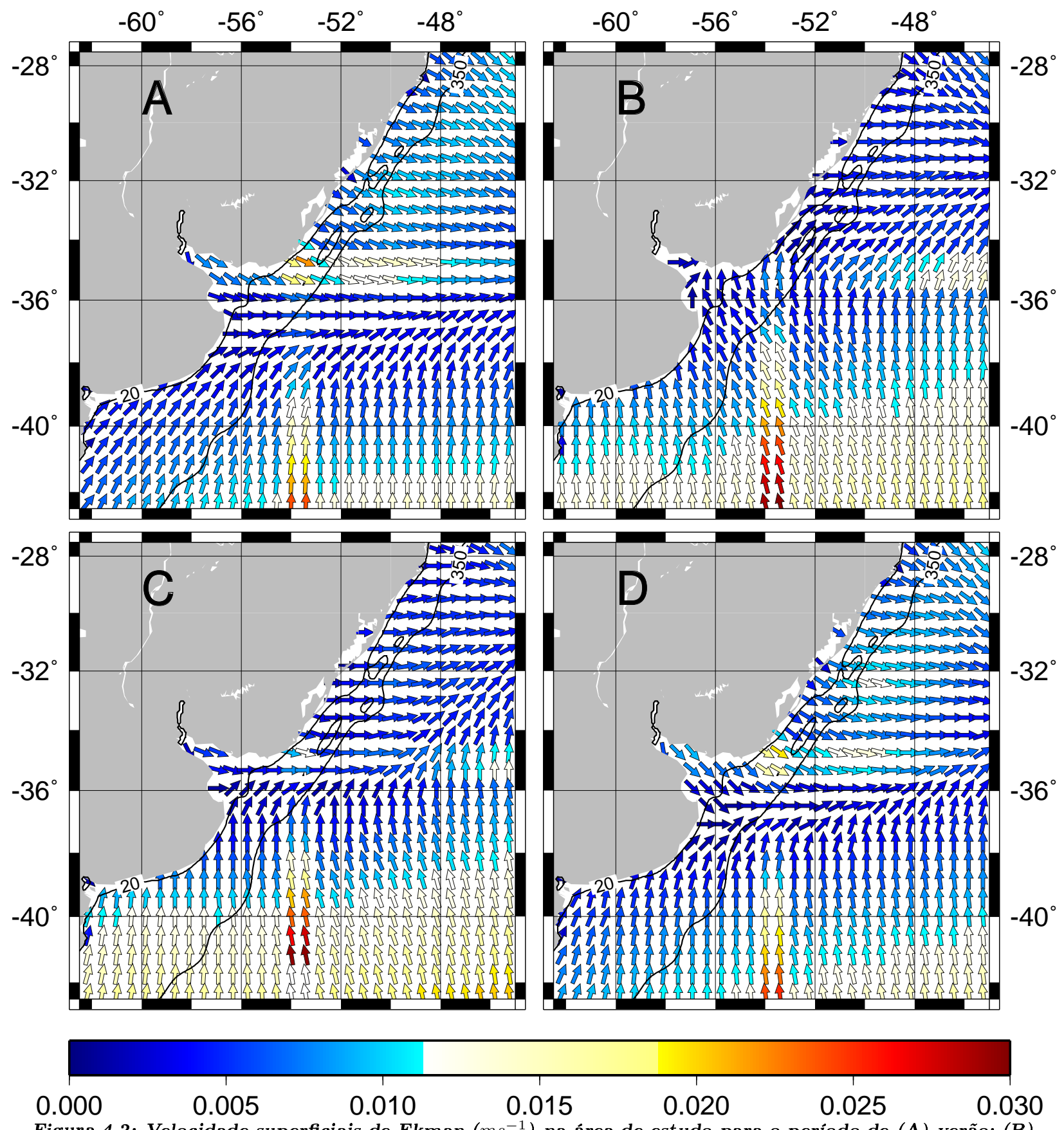

Figura 4.2: Velocidade superficiais de Ekman $\left(m s^{-1}\right)$ na área de estudo para o período de (A) verão; (B) outono; (C) inverno e (D) primavera. Geradas a partir da aplicação dos dados do ECMWF nas equações 4.18 e 4.19. As linhas pretas exibem as isóbatas de 20 e 350 metros 
espaçamento no topo e no fundo, resultando uma maior resolução na camada de fundo e superfície.

O modelo foi inicializado com temperaturas e salinidades de Levitus \& Boyer (1995 apud Palma et al., in prep), suavizados com dados mensais de temperatura da superfície do mar (TSM) provenientes de satélite e salinidade na superfície de registros hidrograficos históricos. Ele foi forçado com tensões de cisalhamento mensais, obtidos do European Center for Medium-Range Forecast (ECMWF) e compilados por Trenberth et al. (1990) e com a descarga fluvial mensal média do Rio da Prata e do Rio Guaíba (na cabeceira da Lagoa dos Patos). O modelo também foi forçado com fluxos de larga escala mensais (Correntes do Brasil e das Malvinas), extraídas do POCM_4C (modelo global) e interpolados nos contornos abertos do modelo.

Para incorporar o efeito friccional das marés, que se torna particularmente importante na porção sul do domínio, o modelo foi forçado em seus contornos abertos com as cinco maiores constituintes tidais extraídas do Modelo Global de Marés da Oregon State University (Egbert et al., 1994).

A batimetria utilizada no modelo é baseada nos dados topográficos de Smith \& Sandwell (1997), com a representação do relevo de fundo da plataforma $(\mathrm{z}<250 \mathrm{~m})$ detalhada por profundidades digitalizadas de cartas naúticas do Serviço Hidrográfico Argentino. As regiões com gradientes topográficos íngremes foram suavizadas com a finalidade de evitar erros do gradiente de pressão associados aos modelos de coordenadas sigma. O período de spin-up do modelo foi de três anos, após o qual o modelo foi rodado por outros três anos. Os resultados utilizados neste estudo foram os gerados no último ano e correspondem a média de três dias.

Os campos de velocidade média sazonal obtidos podem ser observadas na figura 4.3.

O número de larvas de $10 \mathrm{~mm}$ contabilizadas por mês neste experimento é o mesmo mostrado na tabela 4.3.1 e o efeito da turbulência foi considerado.

\subsection{Gráficos de retenção mensal e distribuição longitudi- nal das larvas}

Nesta seção, será feita a descrição da normalização feita nos dados de saída do modelo para a confecção dos gráficos exibidos nas seções 5.1 e 5.2 do Capítulo 5 .

Esta normalização dos dados fez-se necessária por, em alguns meses, ter ocorrido uma desova a mais ou a menos, resultando no lançado um número de larvas diferente para cada mês, como exibido na tabela 4.3.1. Nos gráficos de frequências relativas mensais de larvas retidas, as porcentagens apresentadas foram obtidas através da divisão do número de larvas presentes na região pelo número de larvas lançadas no mês, e o resultado desta operação foi multiplicado por 100 .

Já nos gráficos de distribuição longitudinal das larvas ao longo da plataforma continental, o número de larvas ocorrentes em cada subárea foi dividido pelo número de larvas lançadas no mês e multiplicadas por 20000, que seria a quantidade de larvas lançadas se em todos os meses ocorresse o mesmo número de desovas. Essa quantidade de larvas normalizada foi então dividida pela área da região na qual elas se encontravam, conforme valores exibidos na tabela 

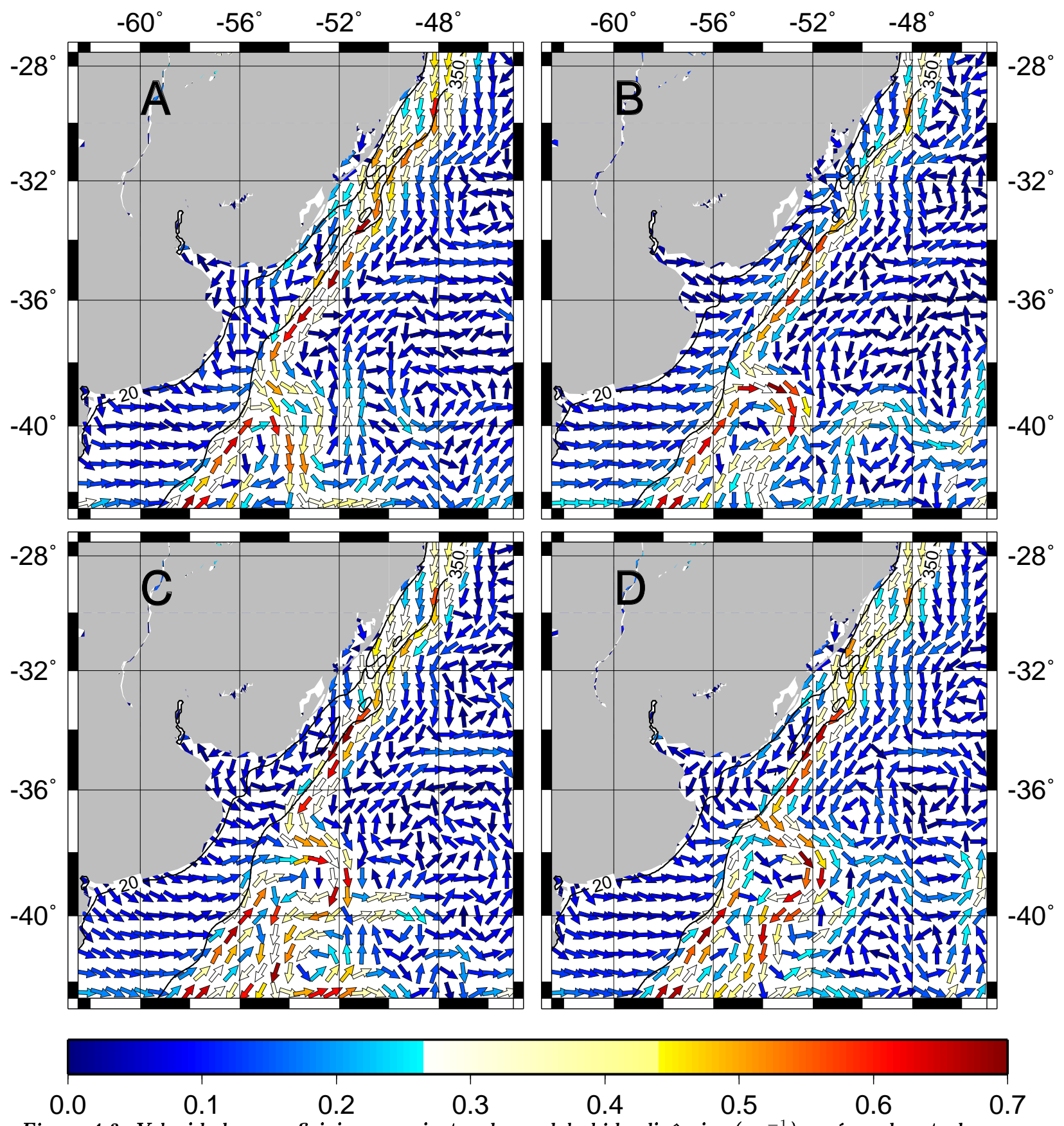

Figura 4.3: Velocidade superficiais provenientes do modelo hidrodinâmico $\left(\mathrm{ms}^{-1}\right)$ na área de estudo para o período de (A) verão; (B) outono; (C) inverno e (D) primavera. As linhas pretas exibem as isóbatas de 20 e 350 metros 


\begin{tabular}{ccccc}
\hline \hline & Área 1 & Área 2 & Área 3 & Área 4 \\
\hline Área de retenção & 52539 & 41441 & 48044 & 58791 \\
Prof. $<20 \mathrm{~m}$ & 25075 & 19948 & 17911 & 6462 \\
$20 \mathrm{~m}<$ Prof. $<100 \mathrm{~m}$ & 24935 & 19526 & 23179 & 24654 \\
$100 \mathrm{~m}<$ Prof. $<200 \mathrm{~m}$ & 2598 & 2317 & 1615 & 9412 \\
$200<$ Prof. $<350$ & 25005 & 19597 & 23249 & 24724 \\
Prof. $>350$ & 404022 & 222591 & 133526 & 293393 \\
\hline \hline
\end{tabular}

Tabela 4.2: Área $\left(\mathrm{em} k \mathrm{~m}^{2}\right)$ das regiões 1, 2, 3 e 4 e de suas subdiviões

4.4. A concentração resultante foi então multiplicada por 100 para facilitar a visualização da mesma, o que gerou uma concentração por $100 \mathrm{~km}^{2}$. A plataforma continental foi dividida de acordo com a profundidade em 4 regiões: profundidades menores que 20 metros, não considerada como área berçário; entre 20 e 100 metros, chamada de Plataforma Interna (PI); entre 100 e 200 metros, Plataforma Média (PM) e entre 200 e 350 metros, Plataforma Externa (PE).

\subsection{Dados de Temperatura e Salinidade}

Os dados de temperatura e salinidades médias sazonais foram obtidos do World Ocean Atlas 2001 (http://www.nodc.noaa.gov/OC5/WOA01/woa01dat.html), seção de campos analisados com 1 grau de resolução. Estes dados foram interpolados para uma resolução de 5 minutos dentro da área de estudo. Os valores de temperatura e salinidade apresentam dados para todos os pontos da região ao longo de todo o ano. A seguir serão apresentadas as médias sazonais de temperatura e salinidade obtidas. Estes valores servirão de base para a discussão das condições de sobrevivência disponíveis para as larvas que permanecerem retidas nas áreas berçário.

\subsubsection{Temperatura}

Observando os gráficos de temperatura superficial média para o verão, outono, inverno e primavera (Fig. 4.4), verifica-se que há uma grande faixa de variação das temperaturas máximas e mínimas nesta região ao longo do ano, de $6^{\circ} \mathrm{C}$ à $24^{\circ} \mathrm{C}$. Esta alta sazonalidade é natural para uma região localizada em latitudes médias.

Durante o verão (figura $4.4 \mathrm{~A}$ ), as menores temperaturas são encontradas abaixo dos $37^{\circ}$ de latitude (área 4), chegando aos $20^{\circ} \mathrm{C}$. Nas áreas 2 e 3 , as temperaturas oscilam entre os 20 e $24^{\circ} \mathrm{C}$, enquanto as temperaturas superficiais da área 1 , a mais quente, chegam aos $25 / 26^{\circ} \mathrm{C}$.

No outono, a temperatura superficial das áreas 3 e 4 varia entre 11 e $15^{\circ} \mathrm{C}$, na área 2 entre 15 e $16{ }^{\circ} \mathrm{C}$ e as temperaturas da área 1 são as maiores, em torno de $18^{\circ} \mathrm{C}$.

Durante o inverno, conforme observado na figura $4.4 \mathrm{C}$, há uma maior penetração para norte de águas frias. A temperatura da área 1 fica em torno dos $15{ }^{\circ} \mathrm{C}$, da área 2 dos $12{ }^{\circ} \mathrm{C}$, 
na 3 a temperatura chega a $10^{\circ} \mathrm{C}$ e na área 4 a $8^{\circ} \mathrm{C}$.

Durante a primavera (fig. $4.4 \mathrm{D}$ ), além das temperaturas atmosféricas atingirem valores mais altos, que causam um aquecimento superficial das águas oceânicas, as águas mais quentes do norte fluem mais intensamente em direção ao sul, havendo um aumento na temperatura superficial média. A área 1 fica com temperaturas superficias médias de 20 a 22 ${ }^{\circ} \mathrm{C}$. Da área 2 para a área 3 a temperatura diminui de 18 para $15^{\circ} \mathrm{C}$, e, novamente, a área 4 é a que apresenta as menores temperaturas, em torno de 12 a $15^{\circ} \mathrm{C}$.

\subsubsection{Salinidade}

A salinidade na plataforma continental da área de estudo, é notadamente influenciada pela descarga fluvial do Rio da Prata e da Lagoa dos Patos, como pode ser observado na figura 4.5.

Durante o verão, os valores mínimos de salinidade observados no estuário do Rio da Prata, Lagoa dos Patos e nas suas desembocaduras é de 24. Na frente da desembocadura do Rio da Prata, não há uma progação notável desta pluma de água doce, e a salinidade permanece em torno dos 30 na área 3. Nesta área, somente na região mais próxima da isóbata dos 20 metros, os valores são menores, em torno dos 27. Na área 4, a salinidade permanece em torno dos 33, salvo sua área mais ao norte, sob influência do Rio da Prata, apresentando valores em torno de 30. A plataforma continental da área 2 apresenta valores de salinidade entre 30 e 32 e a região que apresenta as águas menos salinas é a brasileira, sob uma forte influência da descarga da Lagoa dos Patos, tendo a salinidade variando entre os 23 e os 29 .

No outono (figura $4.5 \mathrm{~B}$ ), o intervalo de variação é o mesmo que para o verão, mas uma aparente diminuição na descarga acarreta um aumento nos valores de salinidade. Na área 4 os valores de salinidade ficam em torno dos 33, e a área sob influência da descarga do Rio da Prata sofre uma ligeira diminuição em seu tamanho, sendo que somente a porção diretamente ligada ao estuário apresenta valores em torno de 30. A salinidade das áreas 2 e 3 também é ligeiramente maior que na última estação, variando entre 30 e 33. A área 1 não apresenta variações em relação à última estação, e a salinidade das águas superficiais tem seu mínimo de 23 na desembocadura da Lagoa dos Patos, diminuindo ao redor da mesma, até atingir 30.

A figura 4.5 C exibe o padrão de salinidade para o inverno, onde o valor mínimo encontrado para a região é de 20 e o máximo (em plataforma) de 35 . A área 1 novamente é a que exibe os menores valores de salinidade, em função das águas provenientes da Lagoa dos Patos. Próximo à desembocadura, os valores chegam à 20, aumentando ao redor da mesma, até chegar a um máximo de 28 . As áreas 2 e 3 apresentam um comportamento muito similar, apresentando um grande gradiente de salinidade na plataforma, com mínimos de 28 e máximos de 34. Já a área 4 apresenta salinidades altas, em torno de 33/34, somente a região próxima a desembocadura apresenta valores mais baixos, em torno de 30 .

Na primavera, (figura $4.5 \mathrm{D}$ ), encontramos para as áreas 2, 3 e 4 o mesmo padrão exibido no inverno. Somente a plataforma continental da região brasileira apresenta valores de salinidade maiores, chegando em algumas regiões, próximos de 31. 


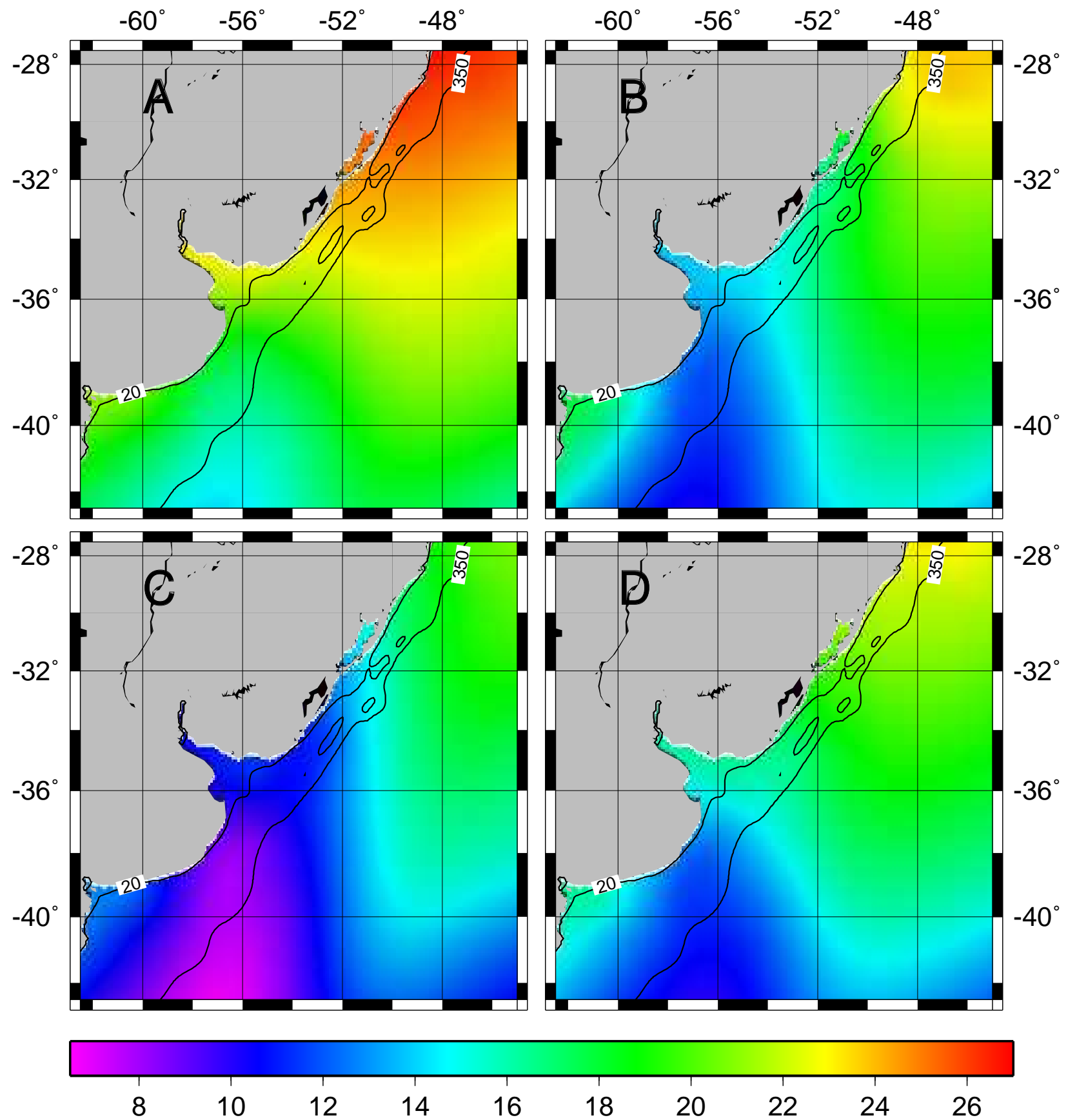

Figura 4.4: Temperatura $\left({ }^{\circ} C\right)$ média superficial na área de estudo para o período de (A) verão, (B) outono,

(C) inverno e (D) primavera. As linhas pretas exibem as isóbatas de 20 e 350 metros. Dados provenientes do Word Ocean Atlas 


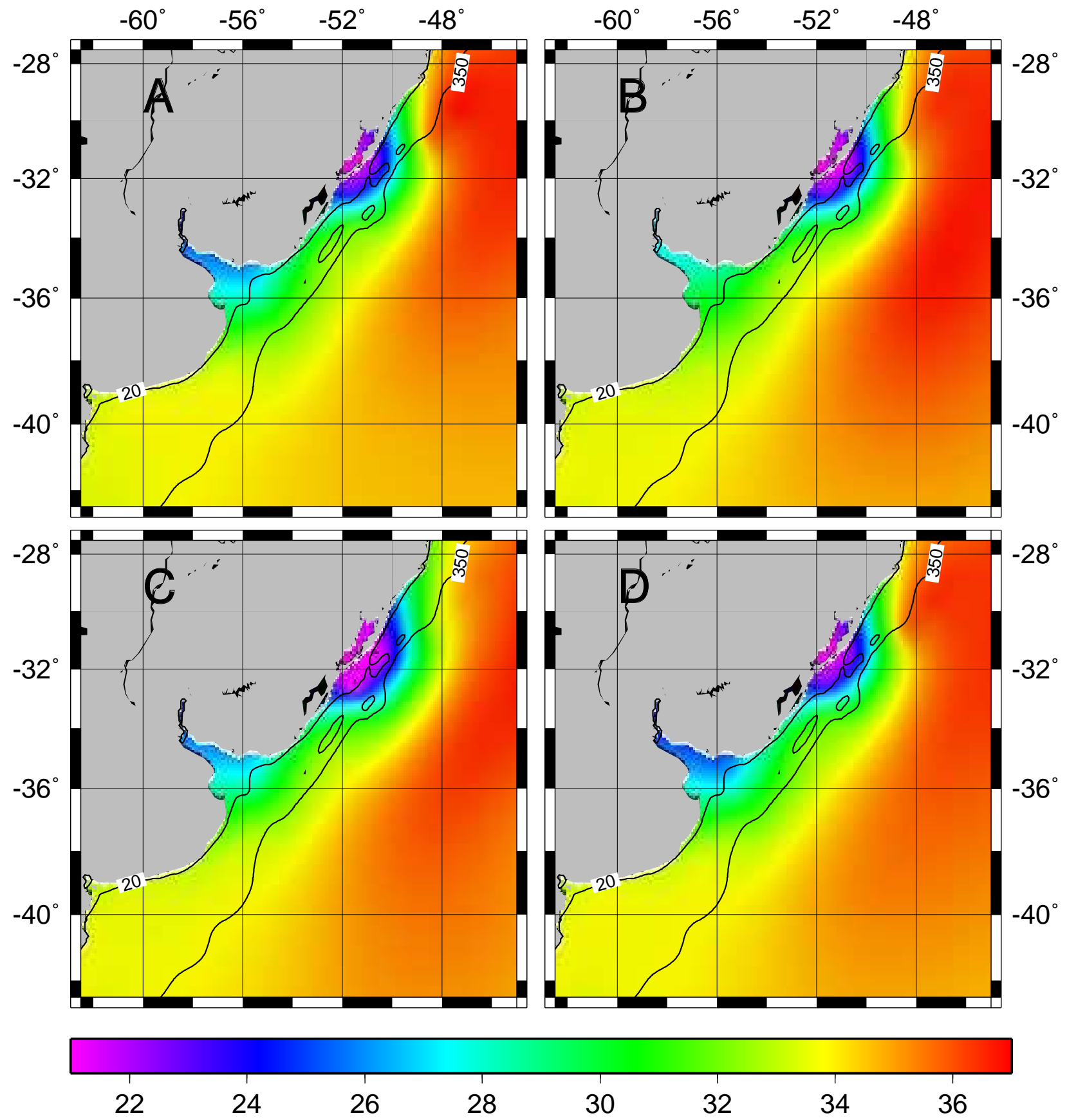

Figura 4.5: Salinidade média superficial na área de estudo para o período de (A) verão, (B) outono, (C) inverno e (D) primavera. As linhas pretas exibem as isóbatas de 20 e 350 metros. Dados provenientes do Word Ocean Atlas 


\subsection{Concentração de ovos e larvas de Engraulis anchoita}

Os resultados observacionais mostrados nos gráficos de 4.6 A a D foram obtidos do trabalho de Muelbert \& Sinque (1995), realizadas com base em 9 cruzeiros oceanográficos.

Pode-se observar na figura $4.6 \mathrm{~A}$, que a concentração larval durante o verão na área de estudo é relativamente baixa. Até os $34^{\circ} \mathrm{S}$ de latitude, a concentração é menor que 10 larvas $/ 100 \mathrm{~m}^{3}$. Somente ao sul da área de estudo, em latitudes maiores que $34^{\circ} \mathrm{S}$ há uma grande presença de larvas, atingindo valores de até 120 larvas $/ 100 \mathrm{~m}^{3}$, para toda a região da plataforma. Durante o outono, não há picos de concentração como no verão, e as maiores concentrações registradas são em torno de 25 larvas/100 $\mathrm{m}^{3}$, em dois núcleos distintos. Um deles é localizado em $28^{\circ} \mathrm{S}$, sobre a plataforma média e o outro em $33^{\circ} \mathrm{S}$, sobre a plataforma externa. Ao longo da costa na área 1 são observadas concentrações constantes, embora não tão altas, de 5 larvas $/ 100 \mathrm{~m}^{3}$.

No inverno, pode-se observar (Fig. 4.6 C) uma grande concentração larval, cerca de 30 larvas $/ 100 \mathrm{~m}^{3}$ ao sul da área de estudo, em aproximadamente $33.5^{\circ} \mathrm{S}$ e se estendendo por toda a região da plataforma. Nessa estação, há uma grande presença de larvas no restante da área 2, cerca de 15 indivíduos $/ 100 \mathrm{~m}^{3}$. Os maiores valores anuais de concentração larval são registrados na primavera (Fig. 4.6 D), quando concentrações de até 200 larvas $/ 100 \mathrm{~m}^{3}$ são observadas ao sul da área 2 , em torno de $34^{\circ} \mathrm{S}$. 
A Engraulis anchoita

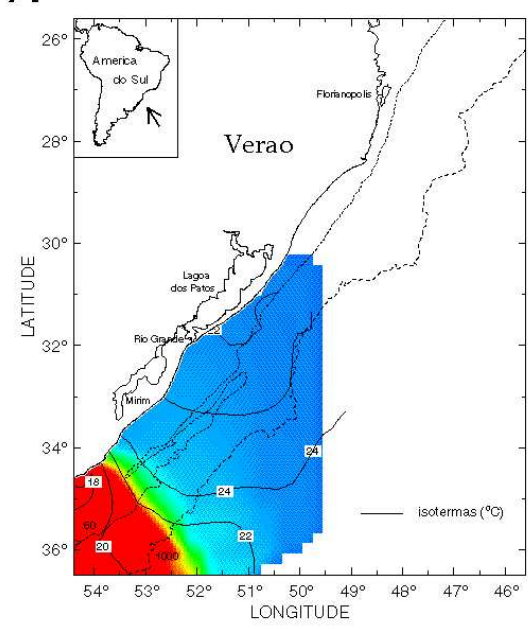

C

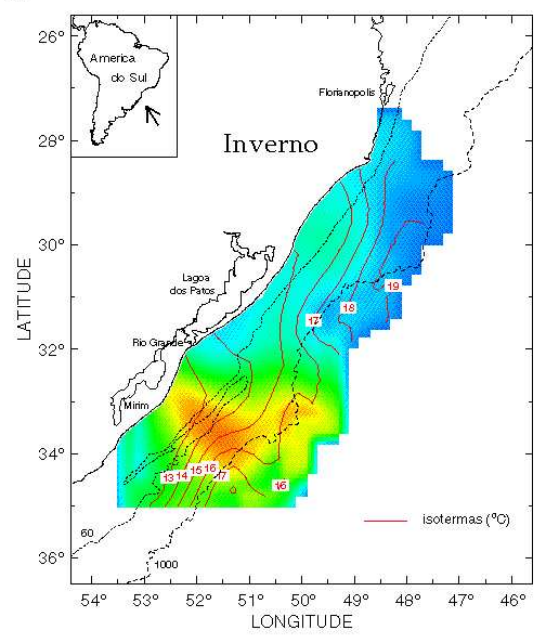

$\mathbf{B}$
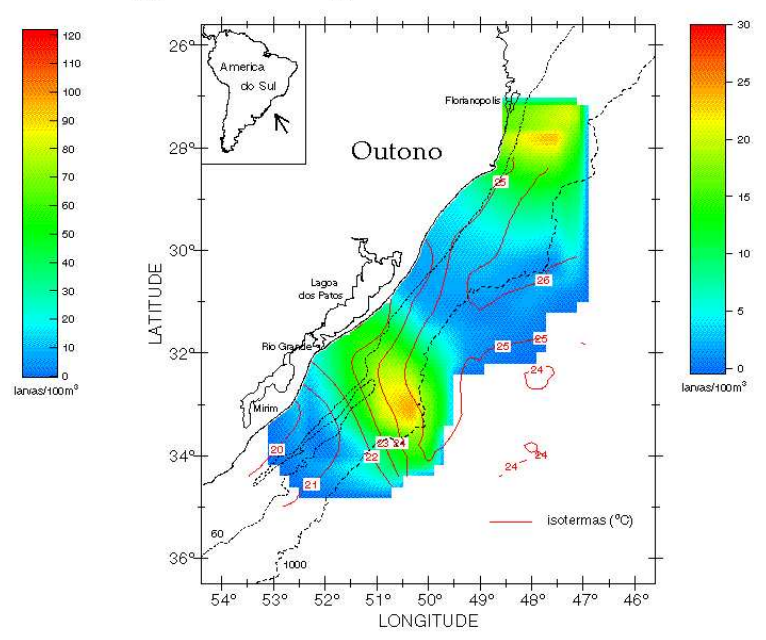

D Engraulis anchoita
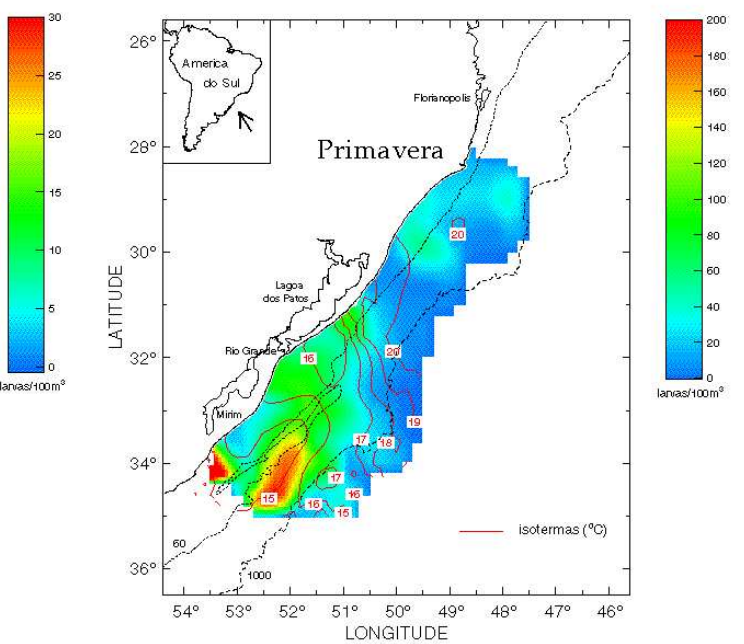

Figura 4.6: Concentração de larvas de anchoíta por $100 \mathrm{~m}^{3}$ para o (A) verão, (B) outono, (C) inverno e (D) primavera. As linhas tracejadas exibem as isóbatas de 60 e 1000 metros. Os valores máximos e minímos de concentração variam entre as estações. Figuras provenientes do trabalho de Muelbert \& Sinque (1995) 


\section{Capítulo 5}

\section{Resultados}

Este capítulo exibe todos os resultados obtidos com o modelo biológico. Inicialmente serão mostrados os resultados obtidos com o modelo alimentado pela deriva superficial de Ekman. A segunda seção traz os mesmos resultados, mas para o modelo alimentado pela saída do modelo hidrodinâmico.

\subsection{Experimento com velocidades de Ekman}

Esta seção apresenta os resultados obtidos no experimento no qual a velocidade superficial de Ekman alimentou o modelo biológico. Os primeiros resultados exibidos são os gráficos de retenção média mensal, das subáreas e da área total. Depois é mostrada a distribuição longitudinal das larvas sobre a plataforma continental, por área de retenção. Por fim, são exibidos gráficos de distribuição de larvas de $10 \mathrm{~mm}$, juntamente com o campo de velocidade. Para estes gráficos, foi selecionado uma distribuição do mês mais significativo de cada estação.

\subsubsection{Retenção e distribuição larval}

A figura 5.1 mostra um gráfico da frequência relativa em porcentagem, de larvas retidas por mês. As linhas exibem qual a porcentagem de larvas retidas em cada área de retenção. Nesta figura pode-se observar que a taxa de retenção apresenta valores altos para todos os meses, próximos de 100\%. Os meses que apresentam uma retenção levemente maior são março, abril, julho e agosto, enquanto as menores são observadas em maio, junho, novembro e dezembro.

Pode-se observar que todas as áreas apresentam uma alta retenção, sempre próxima dos $25 \%$, ou seja, próxima do total de larvas lançadas em cada região. A área que apresenta uma menor retenção é a 1, mas durante os meses de maio, junho e julho os valores de retenção das larvas retidas nesta área torna-se igual a das outras áreas.

A figura 5.2 exibe os valores mensais de larvas não retidas, e as linhas indicam a procedência das larvas não retidas. Os meses que apresentam uma maior perda são os meses de maio, junho, novembro e dezembro e os meses com menor perda são março, abril, julho e agosto. 


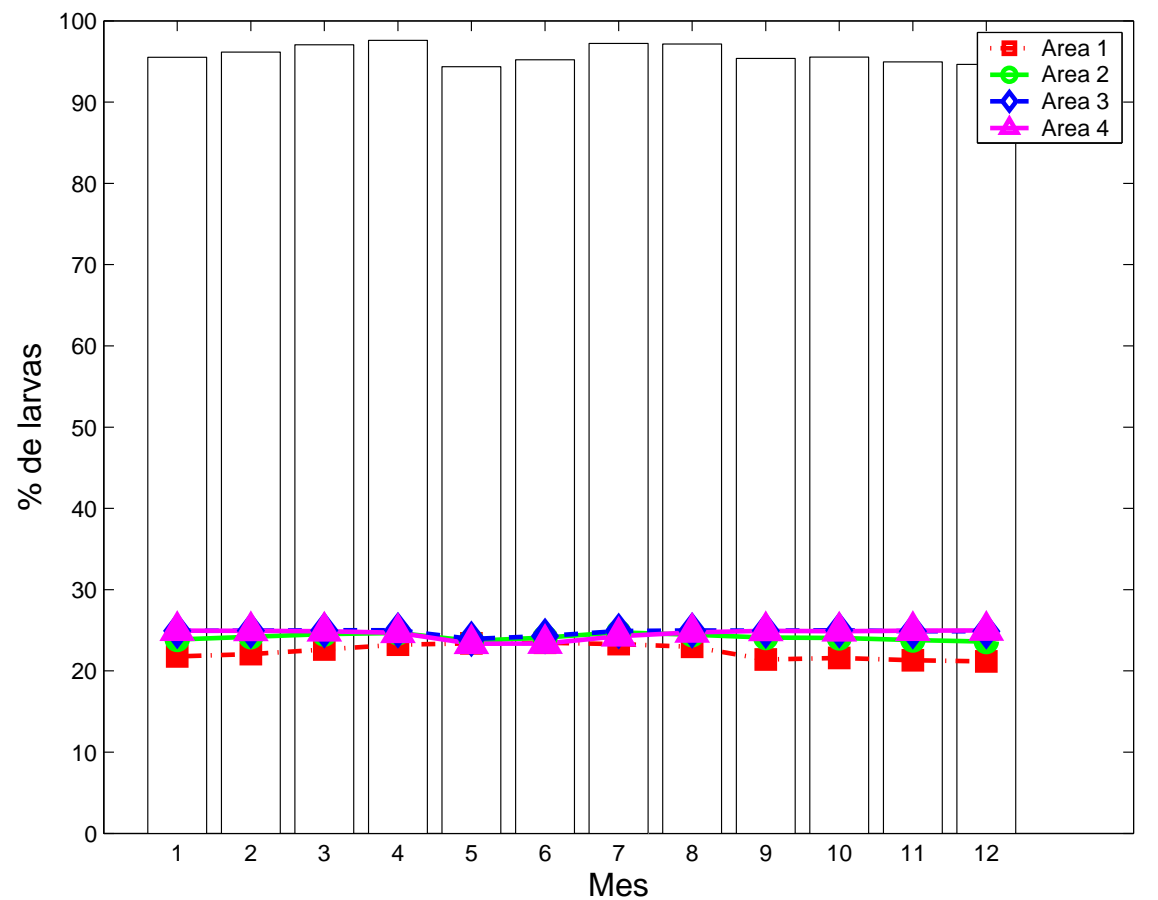

Figura 5.1: Distribuição da frequência relativa de larvas retidas por mês. As linhas exibem a frequência relativa de larvas retidas em cada área (1,2,3 e 4). Experimento utilizando a velocidade superficial da deriva de Ekman

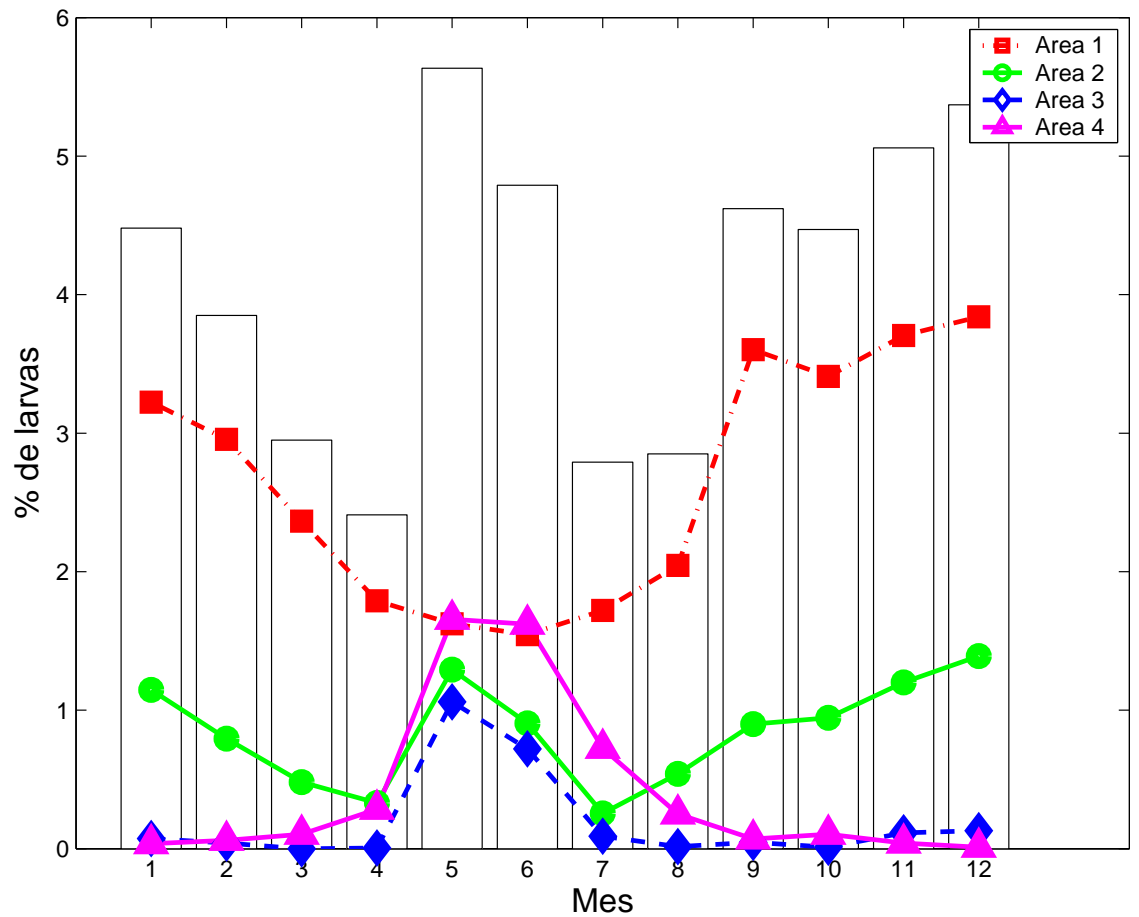

Figura 5.2: Distribuição de frequência relativa de larvas não retidas por mês. As linhas exibem a distribuição de frequência relativa da área de desove (1,2,3 e 4) das larvas não retidas. Experimento utilizando a velocidade superficial da deriva de Ekman 

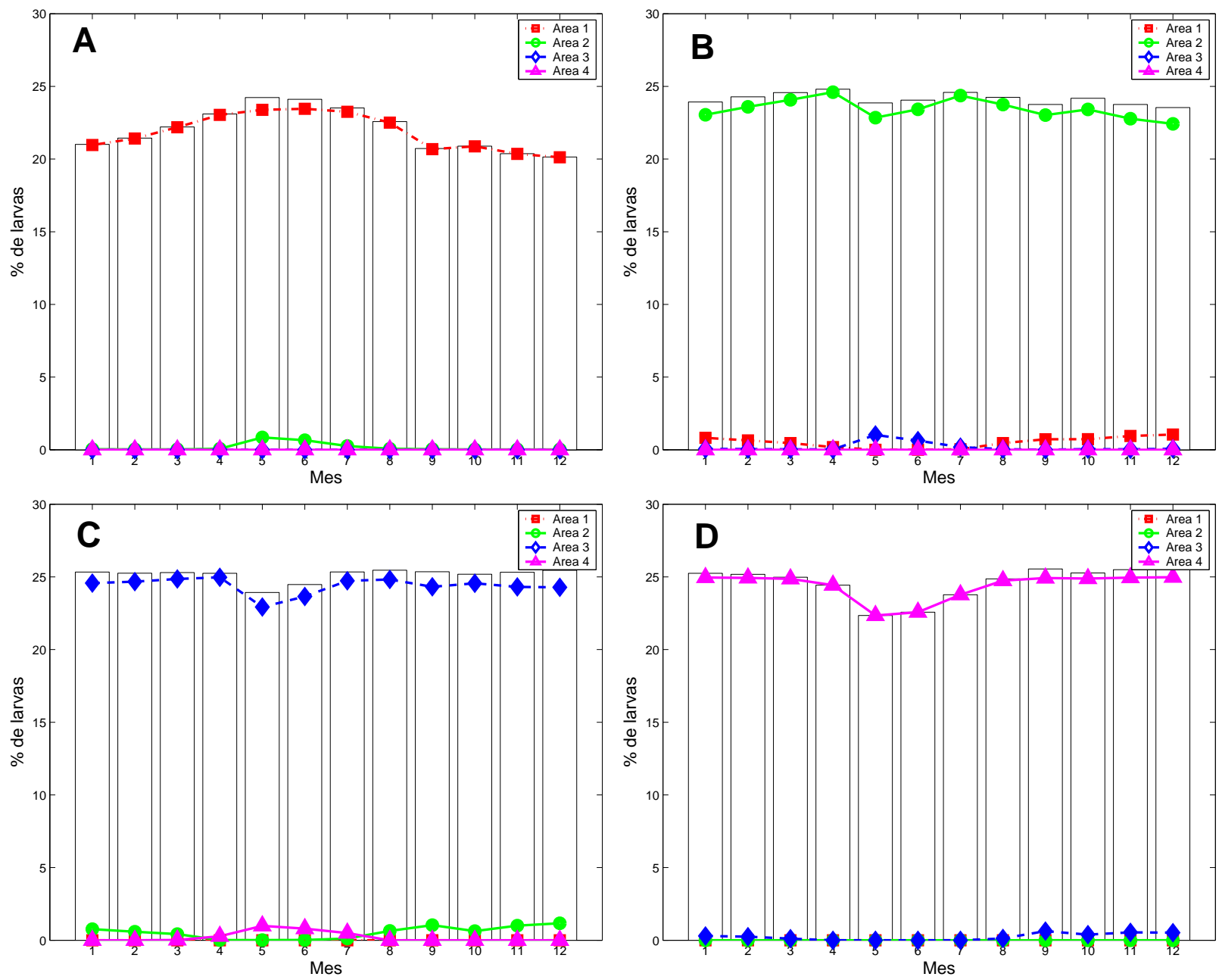

Figura 5.3: Distribuição de frequência relativa de larvas retidas por mês, nas áreas (A) 1 ; (B) 2 ; (C) 3 e (D) 4. As linhas exibem a frequência relativa da área de desova $(1,2,3$ e 4) das larvas retidas. Experimento utilizando a velocidade superficial da deriva de Ekman

A área cujas larvas apresentam uma menor retenção durante todo o ano é a área 1, com $\%$ de larvas fora da área berçário variando entre 1,5\% (maio) e 3,4\% (dezembro), exibindo maiores valores de perda durante a primavera e verão e menores durante o outono e inverno. As larvas da área 2 são mais retidas nos meses de abril e setembro, com perdas de aproximadamente $0,3 \%$ e menos retidas durante o verão e meses de maio e junho. As larvas provenientes das outras áreas apresentam um padrão oposto, tendo as menores retenções durante os meses de maio e junho, especialmente as da área 3 que praticamente não apresentam perdas durante os outros meses do ano.

Na figura 5.3 A pode-se observar o padrão de retenção na área 1, com as linhas exibindo a área de desova das larvas retidas nesta área. Os meses que apresentam uma maior retenção são os meses de outono e inverno, com picos em maio e junho. Os meses com menor retenção são os de primavera e verão, com os valores mínimos ocorrendo em novembro e dezembro. Somente as larvas da própria área 1 são retidas, com excessão dos meses de maio e junho, 
durante os quais algumas larvas da área 2 são retidas (aproximadamente 0,8 \%). Isso indica que não existe um transporte de larvas de outras áreas para o norte ao longo de todo ano, salvo em pequena escala durante estes meses.

Na figura 5.3 B vê-se o padrão de retenção na área 2, com as linhas exibindo a área de desova das larvas retidas nesta área. Esta área apresenta uma retenção aproximadamente constante ao longo do ano, e os meses com menor número de larvas são janeiro, maio, setembro, novembro e dezembro, ao passo que os maiores valores são registrados em abril, maio e julho.

Dezembro é o mês no qual ocorre a menor retenção, $23,54 \%$, e abril a maior, $24,81 \%$, i.e. uma diferença muito pequena, de apenas 1,27 \%. Aproximadamente todas as larvas retidas são aquelas desovadas na própria área. Durante os meses de primavera e verão em torno de $1 \%$ das larvas vêm da área 1, enquanto no inverno estes mesmos $1 \%$ vêm da área 3 , o que mostra que durante estas estações ocorre um pequeno transporte para sul e para norte, respectivamente.

As áreas 3 e 4 (Figs. $5.3 \mathrm{C}$ e 5.3 D) apresentam um comportamento muito semelhante, com valores de retenção máximos (25\%) durante todo o ano, menos durante os meses de maio e junho, quando ocorre uma pequena queda, a qual na área 4 se extende para os meses julho e agosto.

A única diferença entre estas áreas é da origem das larvas retidas. Na área 3 há uma contribuição mensal de larvas das áreas 2 e 4 de aproximadamente 1\%, resultado de um transporte proveniente do norte e do sul, enquanto na área 4 somente nos meses de setembro a janeiro em torno de $0,5 \%$ das larvas retidas são provenientes da área 3 , indicando um transporte na direção sul.

\subsubsection{Distribuição Longitudinal}

O gráfico da figura 5.4 A exibe a quantidade mensal de larvas retidas por $100 \mathrm{~km}^{2}$ na área 1. A região da plataforma continental entre as isóbatas de 20 e $350 \mathrm{~m}$ é a que possui a maior concentração de larvas, quando comparada com as regiões de profundidade menor que $20 \mathrm{~m}$ e maior que $350 \mathrm{~m}$. Essa alta concentração larval ocorre especialmente entre as isóbatas de 100 e 200 metros, que apresenta os maiores valores durante todos os meses do ano, exceto durante maio, onde todas as áreas apresentam a mesma concentração. Na região oceânica é registrada uma quantidade muito baixa de larvas e na região abaixo dos 20 metros é registrada uma quantidade pequena, em torno de 2,7 indivíduos por $100 \mathrm{~km}^{2}$.

A figura $5.4 \mathrm{~B}$ mostra a quantidade mensal de larvas retidas por $100 \mathrm{~km}^{2}$ na área 2 . Nesta figura pode-se observar que o padrão de retenção ainda é muito semelhante ao da área 1, com as menores concentrações ocorrendo nas regiões correspondentes as profundidades menores que 20 metros e maiores que 350 metros, embora seja notado um aumento no número de larvas nesta primeira região, para 5 indivíduos $/ 100 \mathrm{~km}^{2}$. As regiões internas e externas da plataforma apresentam quantidades de larvas semelhantes, exceto nos meses de maio e junho, nos quais ocorre uma maior retenção na plataforma interna. Novamente os maiores valores de larvas aparecem na plataforma média, onde até 22,8 larvas são encontradas por $100 \mathrm{~km}^{2}$, salvo nos meses de maio e junho, nos quais ocorre uma maior dispersão.

A distribuição longitudinal de larvas na área 3 pode ser observada na figura $5.4 \mathrm{C}$. 

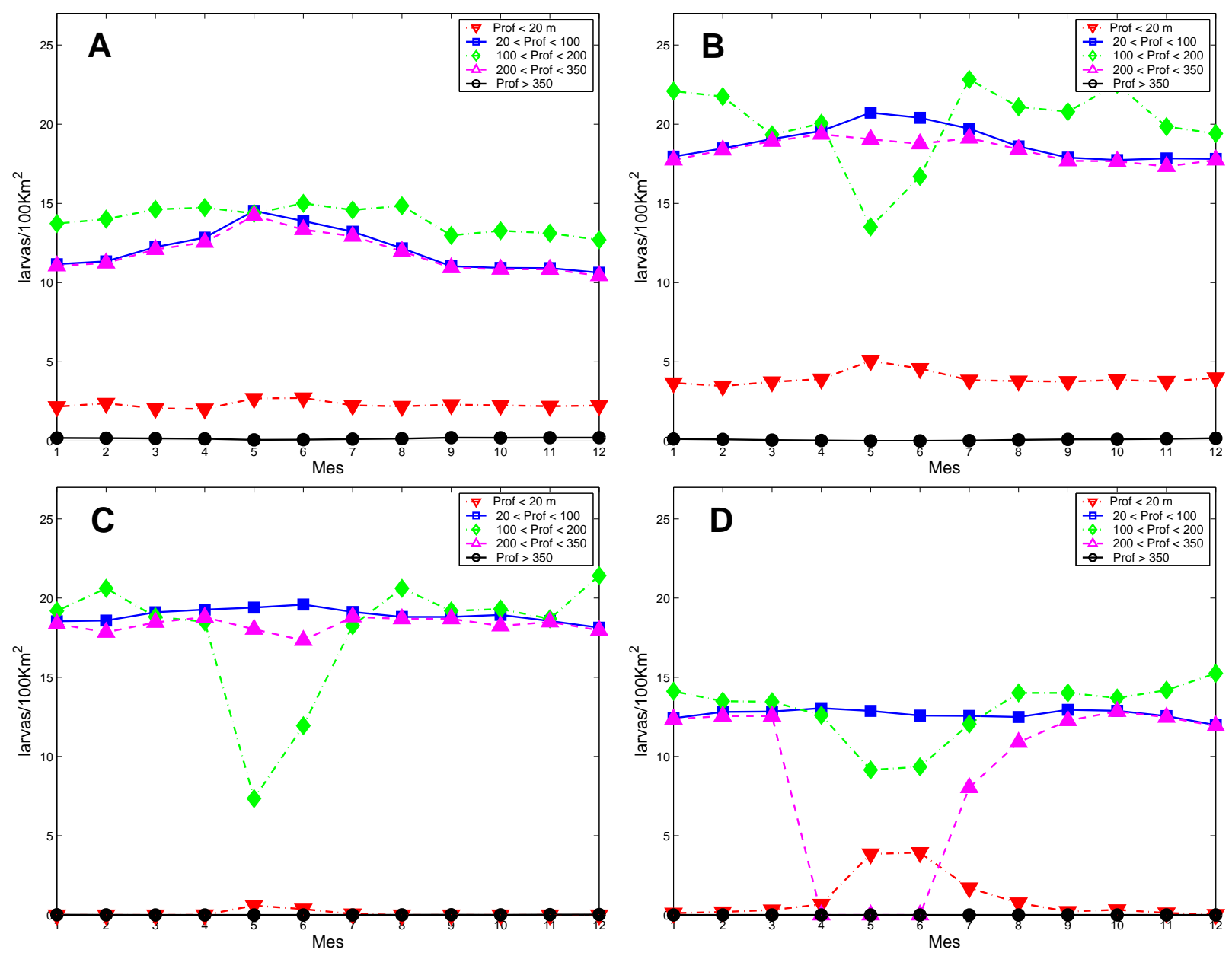

Figura 5.4: Distribuição longitudinal da concentração mensal de larvas por $100 \mathrm{~km}^{2}$ na Área (A) 1 ; (B) 2 ; (C) 3 e (D) 4. Experimento utilizando a velocidade superficial da deriva de Ekman. 
Nesta região a quantidade de larvas retidas nas profundidades menores que 20 metros é praticamente nula, ocorrendo o mesmo para a concentração larval por $100 \mathrm{~km}^{2}$ nas regiões oceânicas. Novamente a retenção na plataforma interna e externa ocorre com a mesma intensidade, menos durante os meses de maio e junho. A região da plataforma média é a que exibe maior concentração larval, embora não com valores tão mais altos quanto o observado nas áreas 1 e 2 . No mês de maio é observado um grande aumento na dispersão das larvas da plataforma média, que continua ocorrendo com forte intensidade durante junho.

A figura 5.4 D mostra o comportamento peculiar na retenção na área 4. Como para todas as outras áreas, a região com profundidades maiores que 350 metros é a que exibe uma menor concentração larval. A região mais costeira, apresenta uma retenção crescente durante os meses de outuno, com picos ocorrendo nos meses de maio e abril, onde até 3,9 indivíduos/100 $\mathrm{km}^{2}$ são retidos. Estes valores diminuem com o início do inverno. A plataforma interna é a região que apresentamaior constância na retenção ao longo do ano, retendo em média 12,5 larvas $/ 100 \mathrm{~km}^{2}$. A plataforma média apresenta valores de retenção levemente maiores que as outras regiões, novamente exceto para os meses de maio e junho. Já na plataforma externa, os valores de retenção larval durante os meses de setembro a março são semelhantes aos da plataforma interna, mas durante o outono a dispersão nesta região é tão intensa que não ocorre retenção, a qual volta a ocorrer durante o inverno, com intensidade crescente até atingir os picos de primavera e verão.

\subsubsection{Distribuição das larvas de $10 \mathrm{~mm}$ e campo de velocidades su- perficiais}

A deriva de Ekman no mês de fevereiro (Fig. $5.5 \mathrm{~A}$ ) é, na maior parte da área de desova, voltada para fora da costa. Salvo na área 4, onde a corrente aparece direcionada paralela à costa, levemente para nordeste. Na área 1 é que aparecem as maiores velocidades, aproximadamente $0,015 \mathrm{~ms}^{-1}$. Na área 2, as velocidades ficam abaixo dos $0,010 \mathrm{~ms}^{-1} \mathrm{e}$ nas áreas 3 e 4 oscilam entre 0 e $0,005 \mathrm{~ms}^{-1}$.

Em relação à distribuição larval, nota-se claramente que na área 1 ocorre a maior dispersão em direção ao oceano, fora da isóbata dos 350 metros.

Durante o mês de maio (Fig. 5.5 B), as correntes são orientadas para a costa, em quase toda a área. Apenas na área 1, a deriva de Ekman ocorre numa direção aproximadamente paralela à costa, direcionada para nordeste, e sua intensidade varia entre 0 e $0,005 \mathrm{~ms}^{-1}$. Na área 2 a velocidade também fica em torno de $0,005 \mathrm{~ms}^{-1}$. Nas áreas 3 e 4 , as velocidades sobre a plataforma externa são maiores, chegando a ultrapassar os $0,010 \mathrm{~ms}^{-1}$, enquanto nas áreas mais costeiras atingem apenas $0,005 \mathrm{~ms}^{-1}$.

Observa-se que ocorre uma grande retenção larval, havendo uma maior dispersão na área 1 em direção ao oceano e uma pequena dispersão em direção à costa acontece nas áreas 3 e 4 .

A figura $5.5 \mathrm{C}$ mostra a circulação na região durante o mês de julho. As correntes nas áreas 1, 2 e 3 fluem paralelas à costa, seguindo para a direção nordeste. $\mathrm{Na}$ área 4 a deriva está direcionada para o norte, e ao sul de seu domínio são observados os maiores valores de velocidade, cerca de $10 \mathrm{~ms}^{-1}$. Nas outras áreas as velocidades ficam em torno dos 0,005 

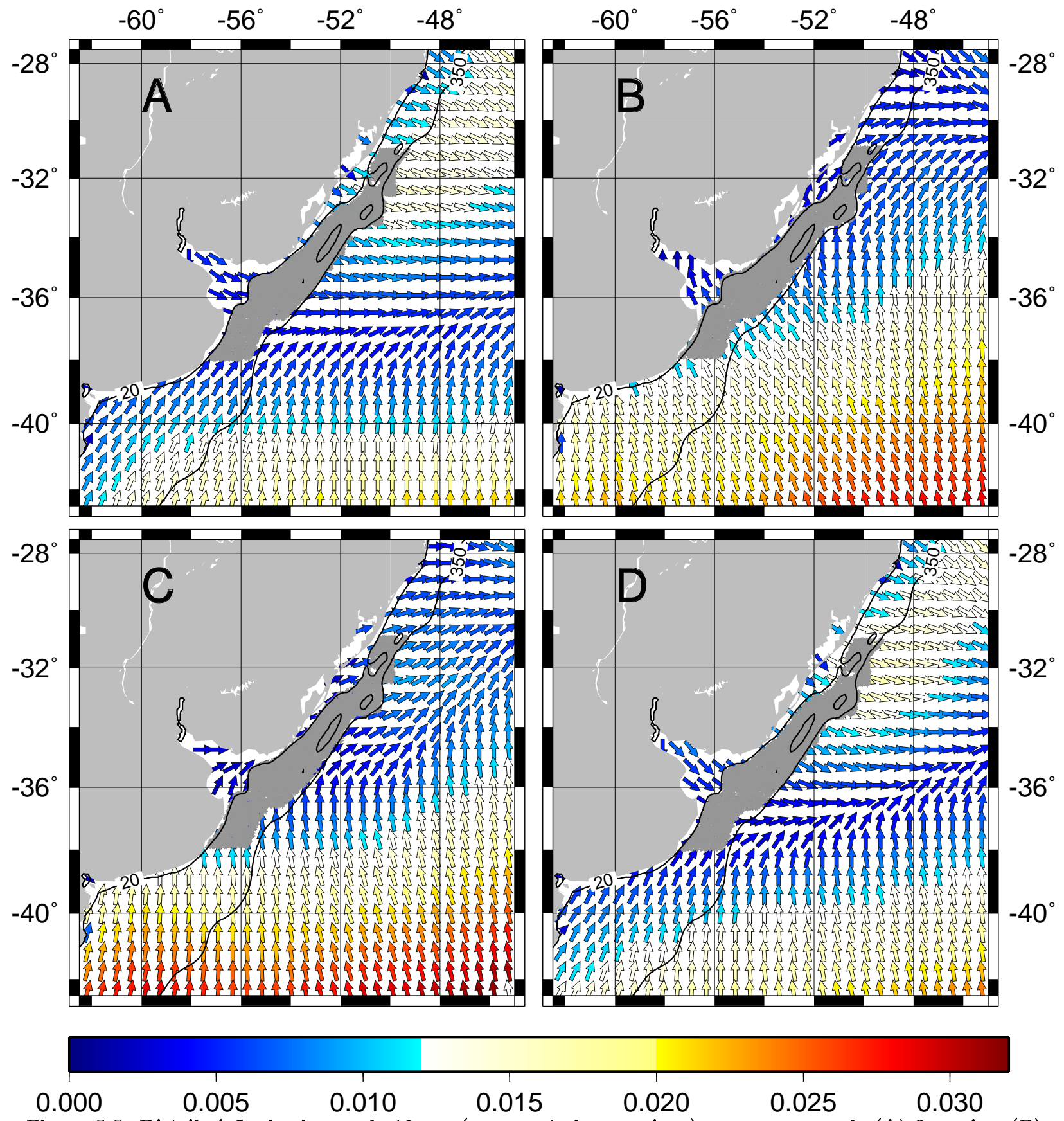

Figura 5.5: Distribuição das larvas de $10 \mathrm{~mm}$ (representadas em cinza) para os meses de (A) fevereiro ;(B) maio; (C) julho e (D) novembro. As setas indicam a direção e a intensidade $\left(\mathrm{ms}^{-1}\right)$ do campo de velocidades superficiais. As linhas pretas representam as isóbatas de 20 e de 350 metros. Experimento utilizando a velocidade superficial da deriva de Ekman 
$m s^{-1}$.

O padrão de dispersão larval é o mesmo apresentado durante o mês de maio.

Em novembro (Fig. 5.5 D), o padrão da circulação gerada pelo vento é parecido com o exibido em janeiro. Nas áreas 1,2 e 3 as correntes estão direcionadas para o oceano e na área 4 para nordeste. As correntes de maior intensidade ocorrem na área 1, atingindo velocidades de até $0,015 \mathrm{~ms}^{-1}$. A velocidade na área 2 fica em torno dos $0,010 \mathrm{~ms}^{-1}$, e nas áreas 3 e 4 oscilam entre 0 e $0,005 \mathrm{~ms}^{-1}$.

A retenção larval é alta em toda a área, mas ocorre um transporte de larvas para o oceano na área 1.

\subsection{Experimento com velocidades do modelo hidrodinâ- mico com turbulência}

Esta seção apresenta os resultados obtidos no experimento em que o modelo biológico foi alimentado pela saída do modelo hidrodinâmico. Os primeiros resultados exibidos são os gráficos de retenção média mensal, das subáreas e da área total. Depois é mostrada a distribuição longitudinal das larvas sobre a plataforma continental, por área de retenção. Por fim, são exibidos gráficos de distribuição de larvas de $10 \mathrm{~mm}$, juntamente com o campo de velocidade. Para estes gráficos, foi selecionado uma distribuição do mês mais significativo de cada estação.

\subsubsection{Retenção e distribuição larval}

O padrão de retenção obtido com o modelo biológico alimentado pelas velocidades superficiais provenientes do modelo hidrodinâmico pode ser visto na figura 5.6. Nesta figura observamos uma clara tendência, com os valores de retenção sendo minímos no início do verão, crescendo com a proximidade do outono e alcançando seus valores máximos durante esta estação. No inverno ocorre uma leve diminuição na retenção, mas os valores se mantém altos e quase constantes, voltando a cair com a chegada da primavera.

Os menores valores ocorrem em dezembro e janeiro, $32,19 \%$ e $37,06 \%$ e os maiores em maio e junho, de $69,35 \%$ e de $70,94 \%$. Os meses de abril, julho, agosto e setembro apresentam valores em torno de $61 \%$. Os valores da quantidade de larvas retidas provenientes da área 1 são os menores, aproximadamente de $2,5 \%$ de julho a abril, com valores mais altos em maio e junho, de $7,29 \%$. Já as larvas originadas da área 2 apresentam taxas de retenção mais constantes ao longo de todo o ano, variando entre $14,17 \%$ (fevereiro) e 20,84\% (junho). Destaca-se o fato das larvas provenientes desta área terem altos valores de retenção de novembro a fevereiro, meses que apresentam uma baixa retenção total. A área 3 apresenta um padrão sazonal mais marcante que a área 2 , mas nem tão marcante quanto a área 4 . As larvas provenientes desta área são as mais retidas durante praticamente todo o ano, salvo nos meses de abril, novembro e dezembro. Os maiores valores encontrados no inverno chegam a 24,28\%. As larvas desovadas na área 4 apresentam valores de retenção com a mais forte variação sazonal. Menores valores são encontrados no final de primavera e início de verão 


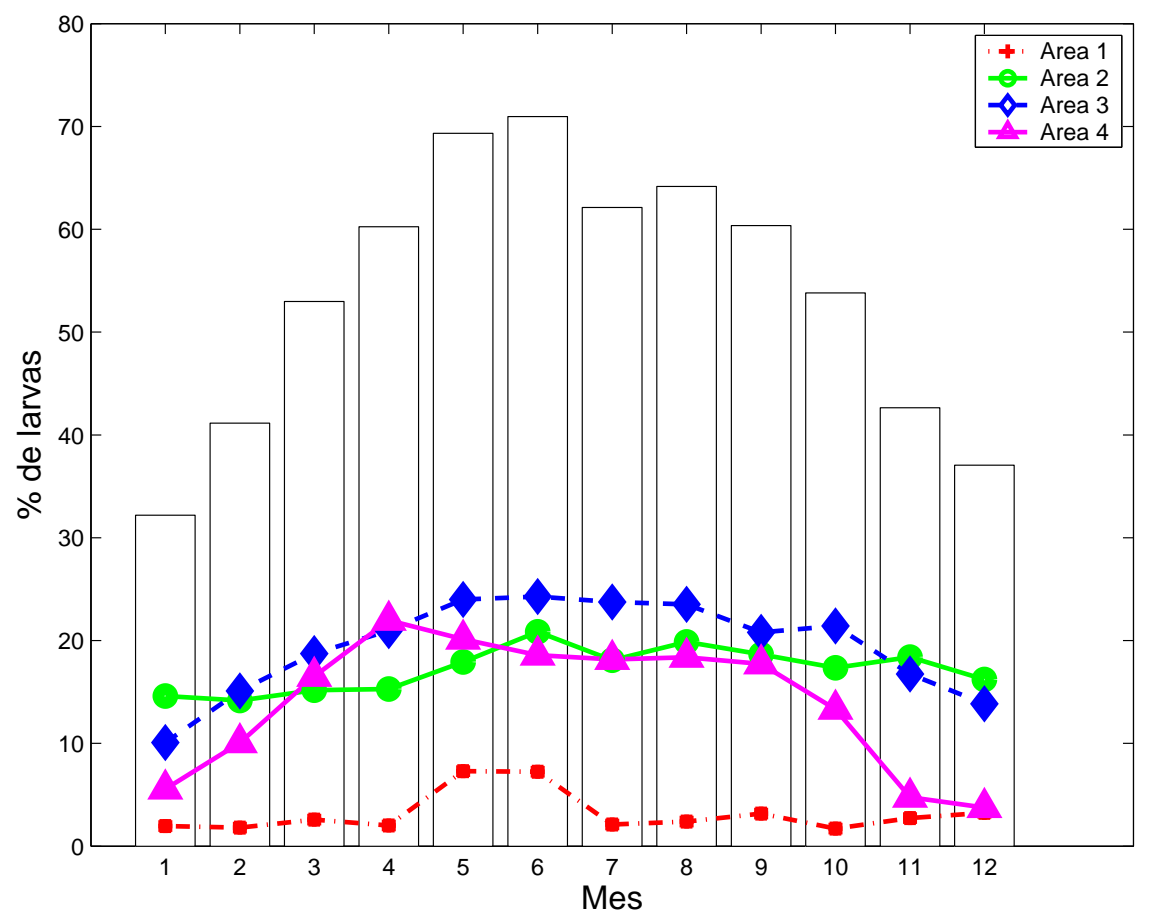

Figura 5.6: Distribuição da frequência relativa de larvas retidas por mês. As linhas exibem a frequência relativa de larvas retidas em cada área (1,2,3 e 4). Experimento utilizando a saída do modelo hidrodinâmico

(3,74\% em dezembro), crescendo durante o outono, com um pico em abril de $21,9 \%$, se mantendo altos durante o inverno $(18,41 \%)$ e voltando a cair no começo da primavera.

A figura 5.7 mostra os valores mensais de larvas não retidas e, como esperado, o padrão é oposto ao exibido na figura 5.6, com menor dispersão das larvas para áreas oceânicas durante os meses de outono/inverno e maior durante os meses de primavera/verão. Em maio esta disperão pode chegar a apenas $30 \%$ e em janeiro a $68,7 \%$.

As larvas originadas em cada área apresentam o mesmo padrão. As larvas vindas da área 1 apresentam os mais altos valores de dispersão, em todo o ano, em torno de $23 \%$, com uma leve queda nos meses de maio e junho para 17\%. A área 2 apresenta um padrão mais constante de perda, em torno de 10\%. Já as larvas da área 3 são as menos dispersadas, especialmente nos meses de outono e inverno (de abril a setembro), quando os valores de dispersão chegam próximos a zero. A área 4 apresenta um marcante padrão sazonal, com uma alta dispersão no final de primavera e início de verão (aproximadamente 20\%).

A porcentagem de larvas retidas por mês para a área 1 exibida na figura $5.8 \mathrm{~A}$ apresenta uma alta variação ao longo do ano. De julho a março os valores de retenção observados são nulos ou próximos de zero, como em agosto 0,08\%, que corresponde a apenas 18 indivíduos de 20000 lançados neste mês. Apenas durante o outono ocorre uma considerável retenção, especialmente durante o mês de maio, onde os valores atingem $12 \%$. A maior parte das larvas encontradas nesta área são provenientes da área 2, como em maio, onde $8 \%$ são da área 2 e $4 \%$ da própria área 1. Também há uma pequena contribuição de larvas da área 3 , de até aproximadamente \%0,5, o que indica um provável transporte para o norte durante 


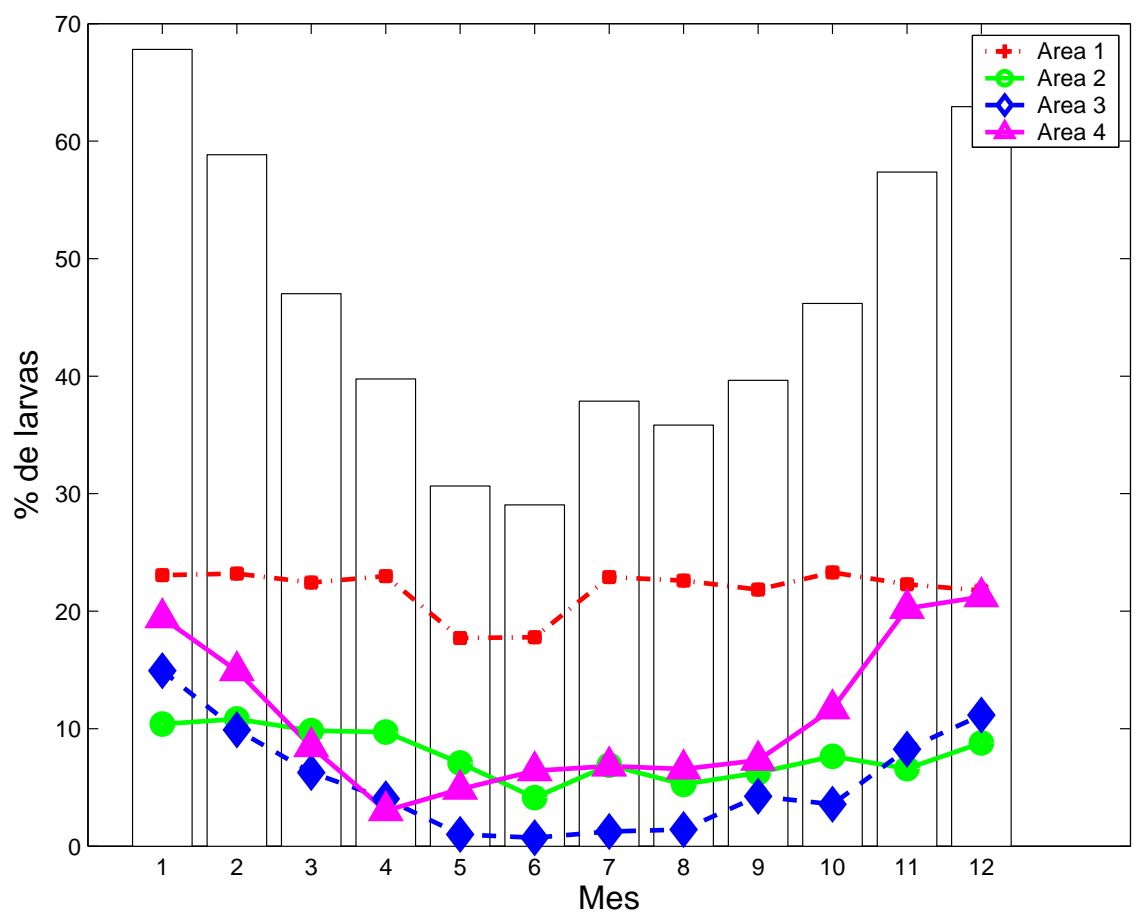

Figura 5.7: Distribuição de frequência relativa de larvas não retidas por mês. As linhas exibem a distribuição de frequência relativa da área de desove (1,2,3 e 4) das larvas não retidas. Experimento utilizando a saída do modelo hidrodinâmico

estas épocas.

O histograma de retenção da área 2 (figura 5.8 B ) apresenta uma variação marcadamente sazonal, embora não tão bem definida quando comparado ao histograma de retenção para todas as áreas. Os meses com menor retenção são os de final de primavera e início de verão, com valores de 2,86\% em dezembro. A partir de março os valores começam a subir, chegando a um pico em maio de $24 \%$ de larvas retidas, quantidade mantida em junho. Durante o inverno, há uma diminuição na retenção, com uma média de 10\%, a qual se mantém no início de primavera, antes de cair. Há larvas de todas as regiões nesta área, embora haja grandes diferenças entre as quantidades presentes. As áreas 1 e 4 são as que menos contribuem, sendo que as larvas da primeira aparecem em quantidades quase constantes ao longo do ano e as da segunda apresentam picos de concentração nos meses de maio e junho. As larvas da própria área 2 são maioria durante todo o ano, salvo durante os meses de maio e junho, quando as larvas provenientes da área 3 são retidas em grandes quantidades, carregadas por um transporte vindo de sul.

A porcentagem de larvas retidas na área 3 está retratada na figura 5.8 C. Nesta figura podemos observar um padrão sazonal diferente do observado até agora. Nesta área o pico de retenção ocorre nos meses de agosto e setembro, alcançando valores de até $26,7 \%$. Durante os meses de final de primavera e início de verão aparece um aumento da dispersão larval, mas não tão intenso quanto para as áreas 1 e 2. Também em contraste com estas áreas, durante os meses de maio e junho menos larvas são retidas, cerca de $16,5 \%$ do que para março, abril, julho, agosto, setembro e novembro, meses nos quais aproximadamente $20 \%$ das larvas 

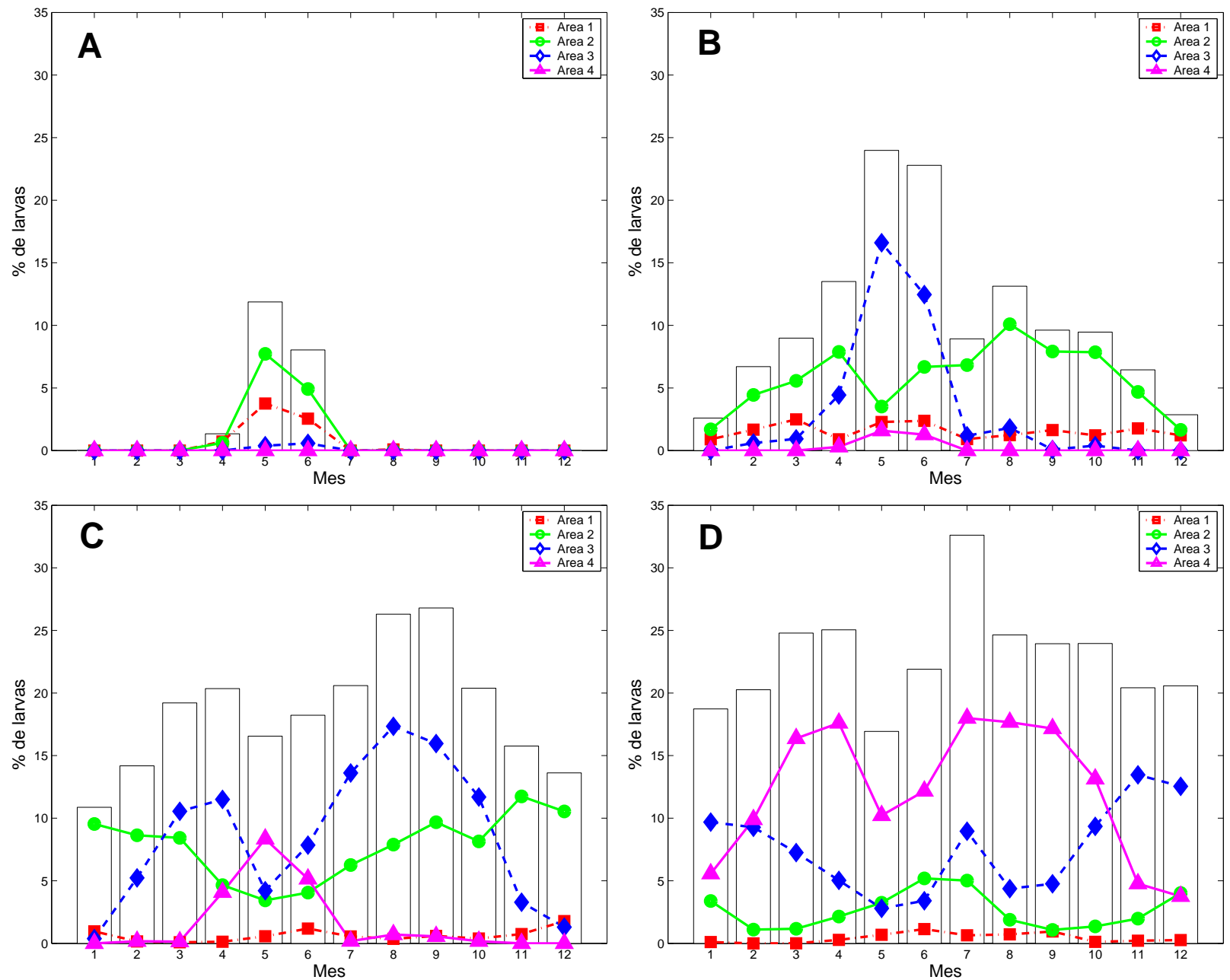

Figura 5.8: Distribuição de frequência relativa de larvas retidas por mês, nas áreas (A) 1 ; (B) 2 ; (C) 3 e (D) 4. As linhas exibem a frequência relativa da área de desova $(1,2,3$ e 4$)$ das larvas retidas. Experimento utilizando a saída do modelo hidrodinâmico 
lançadas permanecem nesta região. A origem das larvas encontradas na área 3 varia bastante ao longo do ano, sendo as larvas lançadas na área 1 a menor presença registrada durante todo o ano, com pico de 1,8\% em dezembro. As larvas provenientes da área 3 são maioria durante o mês de maio, quando são 8,3\% do total. As larvas da área 2 são importantes durante todo o ano, mas especialmente durante a primavera e verão, quando respondem por quase todas larvas retidas, atingindo valores de retenção de até 10,5\%. As larvas originadas na própria área 3 são as mais abundantes em março, abril, e de julho a outubro, com pico de $17,3 \%$.

O padrão de retenção larval da área 4 pode ser visto na figura 5.8 D. Nesta observamos que em todos os meses ocorre uma alta retenção, com um mínimo registrado em maio, de $16,9 \%$ e um máximo em julho, de 32,6\%. Nos meses de março e abril e de agosto a outubro a retenção fica em torno dos $24 \%$ e nos demais meses em torno de $20 \%$, o que representa uma baixa dispersão larval, mesmo nos meses de verão, nos quais são observadas as menores taxas nas outras regiões. As larvas provenientes da área 1 são as menos ocorrentes, com máximos valores de 1,14\%, já as larvas provenientes da área 3 são mais retidas nos meses de final de outono e inicio de inverno e nos meses de final de primavera/início de verão, quando aproximadamente $5 \%$ das larvas retidas são provenientes desta região. Larvas originadas na área 3 apresentam um comportamento variável, e se tornam mais importantes nos meses de novembro, dezembro e janeiro, quando respondem por grande parte das larvas encontradas na região. As larvas originadas na própria área 4 são mais abundantes de março a outubro, havendo uma grande queda dos valores de sua concentração no final de primavera e início de verão.

\subsubsection{Distribuição Longitudinal}

A retenção longitudinal para a área 1 está representada no gráfico da figura 5.9 A, na forma de concentração larval por $100 \mathrm{~km}^{2}$. Durante os meses nos quais ocorre retenção considerável nesta área, de abril a junho, as regiões com maior retenção são as da plataformas interna e externa, com concentrações de até 8,3 indivíduos $/ 100 \mathrm{~km}^{2}$. Durante o mês de maio a retenção larval para a plataforma média é aproximadamente igual a de regiões rasas (profundidades menores que 20 metros), e em junho é cerca de 1,76 larvas $/ 100 \mathrm{~km}^{2}$ maior.

Na figura 5.9 B ve-se a concentração de larvas $/ 100 \mathrm{~km}^{2}$ na área 2 . A menor concentração é nas regiões correspondentes às profundidades maiores que 350 metros. A região costeira apresenta uma retenção relativamente baixa, mas crescente a partir do início do ano até junho, onde ultrapassa os 5 indivíduos por $100 \mathrm{~km}^{2}$ e diminuindo em direção ao final do ano. As regiões da plataforma interna (PI), média (PM) e externa (PE) apresentam o padrão de retenção similar até o mês de julho, embora com diferentes magnitudes. De uma maneira geral os valores para as três regiõesno início do ano é baixo, aumentando com o decorrer do verão, chegando aos valores máximos durante o outono, onde o pico para a PI, PM e PE é de 15,03, 24,77 e 11,88 larvas $/ 100 \mathrm{~km}^{2}$, respectivamente. Estes valores caem com o início do inverno e após julho cada área apresenta suas oscilações na dispersão, mas de maneira geral a dispersão aumenta com o avanço da primavera.

A figura $5.9 \mathrm{C}$ mostra a quantidade mensal de larvas retidas por $100 \mathrm{~km}^{2}$ na área 3 . As maiores retenções nesta área ocorrem na região da PM, que durante os meses de outono e 

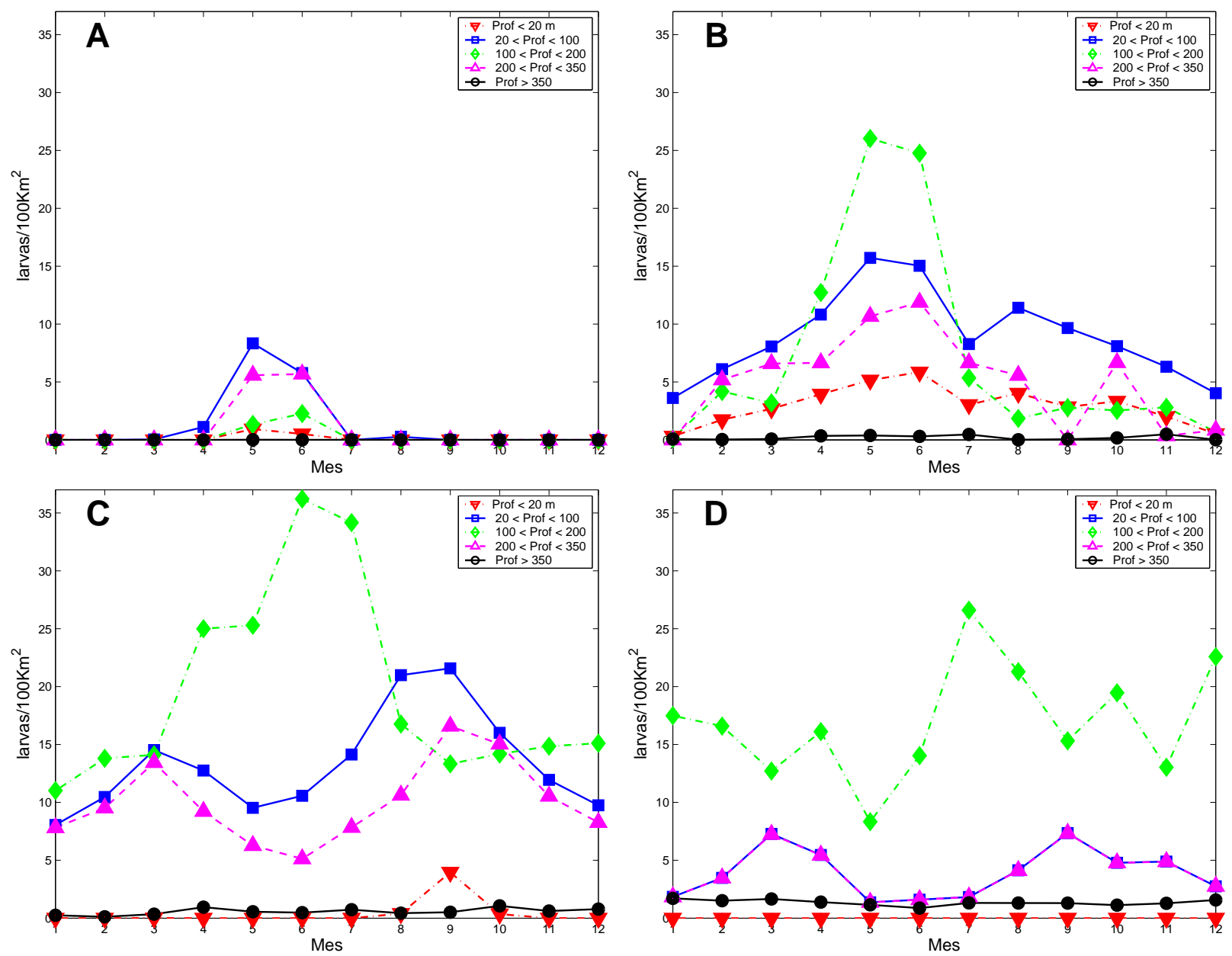

Figura 5.9: Distribuição longitudinal da concentração mensal de larvas por $100 \mathrm{~km}^{2}$ na Área (A) 1; (B) 2; (C) 3 e (D) 4. Experimento utilizando a saída do modelo hidrodinâmico 
inicio de inverno apresenta elevada concentração larval.

A figura $5.9 \mathrm{D}$ mostra a quantidade de larvas por $100 \mathrm{~km}^{2}$ presentes na área 4 , na qual as menores concentrações larvais são encontradas nas áreas costeiras, ao longo de todo ano. As regiões oceânicas também apresenta poucas larvas, com valores de até 1,65 larvas/100 $k^{2}$. A retenção larval nas regiões de PI e PE são similares ao longo de todo ano, com picos de concentração no final do verão e final de inverno (até 7,2 larvas/100 $\mathrm{km}^{2}$ ) e mínimos durante o final do outuno e início de inverno. A região da PM é a que apresenta uma maior retenção ao longo de todo o ano, embora com valores oscilando entre 26,6 e 8,3 larvas/100 $\mathrm{km}^{2}$, apresentando a maior dispersão no mês de maio e a menor durante julho.

\subsubsection{Distribuição das larvas de $10 \mathrm{~mm}$ e campo de velocidades su- perficiais}

A circulação na área de estudo obtida pelo modelo hidrodinâmico, para o mês de janeiro, está retratada na figura 5.10 A. Nela pode-se observar a Corrente do Brasil (CB), fluindo em direção ao sul, com as maiores velocidades sobre a plataforma, especialmente próximo à isóbata dos 350 metros, onde chega a atingir $0,7 \mathrm{~ms}^{-1}$. Também pode-se distinguir claramente a Corrente das Malvinas (CM), seguindo para ao norte com a mesma velocidade máxima da $\mathrm{CB}$, mas fora da isóbata dos 350 metros. A Confluência Brasil-Malvinas (CBM) pode ser observada em aproximadamente $38^{\circ} \mathrm{S}$.

$\mathrm{Na}$ área 1 é que são registradas as maiores velocidades, entre 0,3 e $0,7 \mathrm{~ms}^{-1}$, direcionadas para o sul. A área 2 apresenta velocidades de cerca de $0,3 \mathrm{~ms}^{-1}$, embora possam chegar a $0,7 \mathrm{~ms}^{-1}$ ao norte de seu domínio e sobre a plataforma externa, com a direção do fluxo também voltada para sul. Na área 3 as correntes fluem para fora da costa, aproximadamente para sudeste e, sobre a plataforma interna e média, as velocidades são baixas, entre 0,1 e 0,2 $\mathrm{ms}^{-1}$. Nesta área, apenas sobre a isóbata dos $350 \mathrm{~m}$, são observadas velocidades altas, de até $0,7 \mathrm{~ms}^{-1}$. Na área 4, as correntes fluem para sul, com as menores velocidades, de 0,1 a $0,2 \mathrm{~ms}^{-1}$.

Nota-se que ocorre uma grande dispersão das larvas de todas as áreas em direção às regiões oceânicas. Os organismos lançados nas áreas 1 e 2 também são deslocados para o sul.

Na figura 5.10 B é apresentada a circulação durante o mês de maio. Nela observa-se a diminuição da intensidade da $\mathrm{CB}, \mathrm{CM}$ e $\mathrm{CBM}$ durante o outono. A CB flui sobre a plataforma externa das áreas 1,2 e 3 . Na área 1 ela flui com uma velocidade média de 0,45 $\mathrm{ms}^{-1}$, na área 2 atinge sua maior velocidade, cerca de $0,7 \mathrm{~ms}^{-1}$, a qual é mantida sobre a área 3, onde a CB se propaga fora da isóbata dos $350 \mathrm{~m}$. A CM apresenta velocidades altas, de $0,7 \mathrm{~ms}^{-1}$, na plataforma externa da área 4 . A posição da Confluência permanece em torno dos $38^{\circ} \mathrm{S}$.

As correntes observadas dentro da plataforma em todas as áreas são fracas, com velocidades em torno de 0,1-0,2 $\mathrm{ms}^{-1}$. Nas áreas 1, 2 e 3 elas fluem paralelas à costa na direção nordeste, com o transporte em alguns trechos voltados para a costa e na região da desembocadura da Lagoa dos Patos voltado para o oceano. Já na área 4 as correntes fluem para fora da costa. 

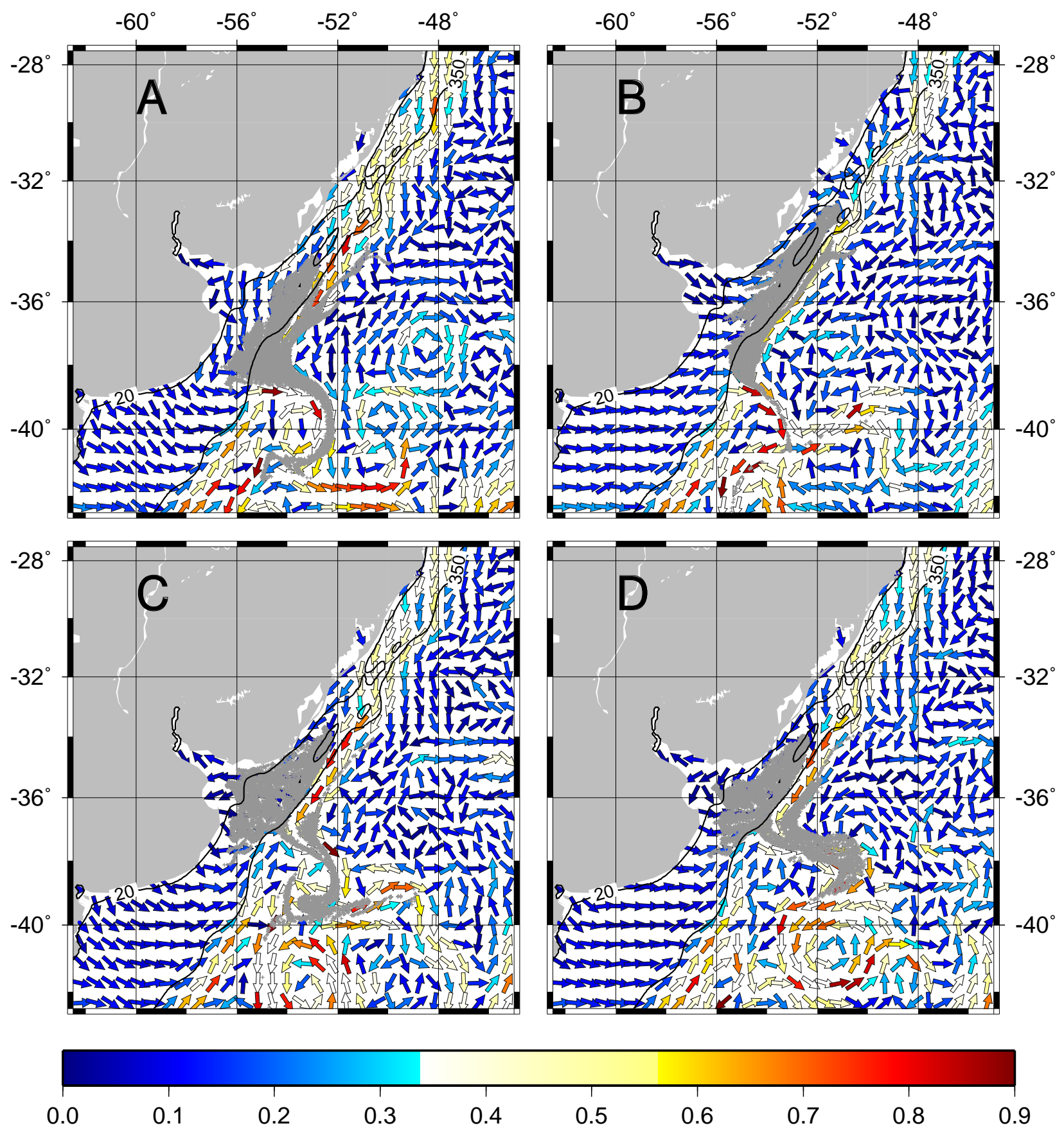

Figura 5.10: Distribuição das larvas de $10 \mathrm{~mm}$ (representadas em cinza) para os meses de (A) janeiro ;(B) maio; (C) setembro e (D) novembro. As setas indicam a direção e a intensidade ( $\mathrm{ms}^{-1}$ ) do campo de velocidades superficiais. As linhas pretas representam as isóbatas de 20 e de 350 metros. Experimento utilizando a saída do modelo hidrodinâmico 
Podemos observar pela distribuição das larvas que as originadas na área 1 são advectadas ao sul, mas com menos intensidade que durante o verão. Já os organismos lançados nas áreas 3 e 4 são transportadas para o norte. Novamente a CB e a CBM parecem ser responsáveis por grande parte do transporte larval para as regiões oceânicas.

O padrão de circulação para o mês de setembro pode ser visto na figura $5.10 \mathrm{C}$. Pode-se observar o início da intensificação da CB, notada pelo aumento da sua área. Ela passa a fluir sobre uma porção maior da plataforma continental, especialmente na área 1 , mas os valores observados para sua velocidade ainda são bem inferiores aos de verão, ficando em torno de 0,4 a $0,5 \mathrm{~ms}^{-1}$, mesmo sobre a isóbata de $350 \mathrm{~m}$. A CM durante este mês de final de inverno aparece com a mesma intensidade de maio. A posição da Confluência está mais ao norte, em torno de $37^{\circ} \mathrm{S}$.

As correntes nas áreas 1 e 2 fluem em direção ao sul, sendo que as velocidades na primeira são maiores, entre 0,4 e $0,5 \mathrm{~ms}^{-1}$ e na segunda entre 0 e $0,2 \mathrm{~ms}^{-1}$. As áreas 3 e 4 apresentam velocidades fluindo em todas as direções, formando um pequeno, giro anticiclônico sobre a plataforma em frente a desembocadura do Rio da Prata. As velocidades nesta área também são pequenas, oscilando de 0 a $0,2 \mathrm{~ms}^{-1}$.

A distribuição das larvas acompanha as feições físicas observadas. Na área 1, não aparecem concentrações de organismos, que podem ter sido advectados para sul pelo forte fluxo com esta direção. Já as regiões que apresentaram baixas velocidades mostram uma grande retenção de organismos, especialmente em frente ao estuário do Rio da Prata. Novamente, a maior advecção de larvas para o oceano aparenta estar associada a CB e a CMB.

A figura 5.10 D mostra a circulação e a dispersão larval para o mês de novembro. A CB continua apresentando uma menor magnitude em termos de velocidade que para os meses de verão. Os maiores valores são encontrados sobre a isóbata de 350 metros. A CM apresenta a mesma intensidade observada nos outros meses e a posição da CBM permanece em torno $\operatorname{dos} 37^{\circ} \mathrm{S}$.

A área 1 é a que apresenta as maiores velocidades, de 0,3 a $0,5 \mathrm{~ms}^{-1}$, com o fluxo direcionado para sul. As correntes na área 2 apresentam velocidades muito pequenas, de 0 a $0,1 \mathrm{~ms}^{-1}$. Nesta área, próximo a costa (sobre a isóbata de 20 metros), há uma corrente fluindo para sul, sobre a plataforma média ela está direcionada para fora da costa, enquanto sobre a plataforma externa ela flui para norte na metade sul do domínio e para sul na metade norte do domínio. Na área do Rio da Prata o fluxo é direcionado para o oceano, e as velocidades são muito pequenas $\left(0-0,1 \mathrm{~ms}^{-1}\right)$. Na área bonairense as correntes também têm essa direção, mas com uma leve inclinação para nordeste. Nesta região são registradas velocidades próximas a costa de $0,1 \mathrm{~ms}^{-1}$, enquanto próximo à isóbata de 350 metros, elas ultrapassam os $0,2 \mathrm{~ms}^{-1}$.

Novamente a área 1 não apresenta larvas, provavelmente devido ao transporte para sul ocasionado pela circulação na área. As áreas 2, 3 e 4, que apresentam menores velocidades, apresentam uma grande quantidade de larvas, mas durante este mês, não ocorre uma penetração das mesmas em direção ao estuário do Rio da Prata. Como observado em todas as outras estações, a CB e a CMB aparecem relacionadas à dispersão de uma grande quantidade de organismos. 


\section{Capítulo 6}

\section{Discussão}

A discussão será feita em quatro partes distintas. Na primeira seção, é discutido o desempenho do IBM desenvolvido para representar os estágios iniciais de vida da anchoíta. Na segunda seção, são discutidos os resultados de transporte e retenção obtidos com a utililização da velocidade superficial de Ekman e com o modelo hidrodinâmico. Na terceira seção, é realizada a comparação destes resultados com dados observacionais da região. Na quarta e última seção, discorre-se sobre as chances de sobrevivência das larvas retidas.

\subsection{IBM para os estágios iniciais do ciclo de vida da an- choíta na PCAS}

O IBM desenvolvido neste trabalho constitui um modelo simples, mas que contém os três constituintes principais apontados por Pedersen et al. (2003) para ser operacionalmente viável: um modelo hidrodinâmico, capaz de retratar campos de fluxos; um esquema de adveç̧ão, que simula o transporte dos indivíduos; e um modelo biológico, que simula processos como desova, eclosão e crescimento. O IBM simula o movimento das partículas através de uma abordagem lagrangeana. Grande parte dos modelos de transporte de plâncton, mesmo os que não usam modelagem baseada no indivíduo, dão um enfoque lagrangeano. Segundo Ozgokmen et al. (2000), é natural a escolha do uso de dados lagrangeanos para a previsão da dispersão de partículas, dado que as mesmas se movem com o fluxo. Além disso, a partir de apenas alguns dados, podem ser assimiladas informações nas equações que governam o movimento das partículas.

Broekhuizen et al. (2003) utilizou-se de um IBM para estudar a dinâmica populacional do fitoplâncton, através do método lagrangiano para considerar a estrutura fisiológica em escala local de uma população. Batchelder et al. (2002) acoplaram um modelo hidrodinâmico costeiro bidimensional e um modelo ecológico euleriano a um IBM, o qual foi construído para simular copépodos capazes de realizar migração vertical, com a finalidade de estudar a produtividade de um sistema de ressurgência. Adlandsvik et al. (2004), modelaram o transporte e a dispersão de ovos e larvas de Greenland halibut a fim de prever a localização dos sítios de recrutamento. Foram usados campos de correntes de um modelo hidrodinâmico baroclínico 3D para alimentar um modelo lagrangeano de trajetória de partículas. Sentchev 
\& Korotenko (2004) também utilizaram esta abordagem para estudar como a combinação do efeito da maré e da flutuabilidade de água doce afetavam a acumulação e transporte horizontal de organismos no Canal Leste Inglês. Skongen et al. (2003) estudaram como as variações no padrão de transporte das larvas a partir das áreas de desova podiam explicar a variabilidade no sucesso do recrutamento da anchova Engraulis capensis. Lyne \& Thresher (1994) criaram um modelo lagrangeano de deriva larval para verificar se somente o mecanismo de transporte passivo era responsável pelo padrão de distribuição das larvas de Macruronus novaezealandiae ao longo da costa da Tasmânia.

Dada a inexistência de estudos prévios na PCGU e PCAU que tratassem do transporte de ovos e larvas a partir de medidas contínuas de velocidade, foi escolhida a utilização de um modelo com uma abordagem tradicional, considerando os ovos e larvas como partículas passivas, sendo advectadas por um campo de velocidade superficial. De acordo com trabalhos prévios, essa escolha se mostra adequada, como os de Allain et al. (2003); Huggett et al. (2003); Mullon et al. (2002 e 2003) e Parada et al. (2003). Todos utilizaram modelos hidrodinâmicos acoplados a IBMs para estudar diferentes aspectos do recrutamento de Engraulis capensis, com uma abordagem lagrangeana, onde as larvas foram tratatas como partículas passivas sendo transportadas pelas correntes oceânicas. Alguns dos parâmetros requeridos pelo modelo são tamanho, densidade e concentração dos ovos, locais e datas de desova.

Outros trabalhos, como de Letcher et al. (1996), Hinrichsen et al. (2002) e Bartsch \& Coombs (2004) utilizaram modelos mais elaborados: o primeiro visava classificar, por ordem de importância, os fatores responsáveis pela mortalidade nos estágios larvais; o segundo analizou a variabilidade intra e interanual no crescimento e sobrevivência das larvas de bacalhau no Mar Báltico; e o último visava prever a sobrevivência nos estágios larvais da cavala no Atlântico Norte leste. Estes trabalhos utilizam submodelos que calculam, além do deslocamento e crescimento, a taxa de encontro com presas, as taxa de captura e a morte por inanição, entre outras variáveis. Seria de grande importância realizar esse tipo de estudo para os estágios larvais da Engraulis anchoita na PCAS, o qual fica como sugestão para futuros trabalhos.

O método adotado para a integração espacial no cálculo do deslocamento das partículas, Runge-Kutta de quarta ordem, mostrou-se uma boa escolha. O outro método amplamente utilizado é o esquema de Euler, cuja fórmula é dada por:

$$
y_{n+1}=y_{n}+h f\left(x_{n}, y_{n}\right)
$$

Esta fórmula avança a solução de $x_{n}$ para $x_{n+1}=x_{n+h}$ e é assimétrica, porque avança a solução através de um intervalo $h$, mas utiliza informação do início do intervalo. Isso significa que o erro por passo é apenas uma ordem de $h$ menor que a correção $\left(\mathrm{O}\left(h^{2}\right)\right)$ adicionada à equação. Segundo Press et al. (1994), este método não é recomendado para uso prático, por não ser muito estável e nem tão acurado quando comparado a outros rodados no mesmo passo de tempo.

O método de Runge-Kutta surge ao utilizar-se de um passo como na equação 1, mas com a tentativa de um passo no meio do intervalo, usando o valor de $x$ e $y$ no ponto médio para computar o passo "real" através de todo o intervalo: 


$$
\begin{gathered}
k_{1}=h f\left(x_{n}, y_{n}\right) \\
k_{2}=h f\left(x_{n}+1 / 2 h, y_{n}+1 / 2 K_{1}\right) \\
y_{n+1}=y_{n}+k_{2}+O\left(h^{3}\right)
\end{gathered}
$$

Como o termo de erro indica, essa simetrização cancela o termo de erro de primeira ordem, tornando o método de segunda ordem, o qual é chamado de Runge-Kutta de segunda ordem. Pode-se continuar a melhorar o método, eliminando os termos de erro de ordem maiores. $\mathrm{O}$ mais utilizado é a clássica fórmula de Runge-Kutta de quarta ordem, escrita como:

$$
\begin{gathered}
k_{1}=h f\left(x_{n}, y_{n}\right) \\
k_{2}=h f\left(x_{n}+h / 2, y_{n}+K_{1} / 2\right) \\
k_{3}=h f\left(x_{n}+h / 2, y_{n}+K_{2} / 2\right) \\
k_{4}=h f\left(x_{n}+h / 2, y_{n}+K_{3}\right) \\
y_{n+1}=y_{n}+k_{1} / 6+k_{2} / 3+k_{3} / 3+k_{4} / 6+O\left(h^{5}\right)
\end{gathered}
$$

Este método requer quatro resoluções por passo de tempo $h$, sendo geralmente superior ao de segunda ordem. O método de Runge-Kutta trata cada passo numa sequência de maneira idêntica e o comportamento anterior da solução não é usado na sua propagação, o que torna fácil a incorporação do método em esquemas simples de percurso (Press et al., 1994)

Diversos outros trabalhos, com a mesma abordagem deste, fazem uso de modelos semelhantes, traçando trajetórias de partículas utilizando o método de Runge-Kutta. Os trabalhos de Oliveira et al. (2002), Garcia-Martinez \& Flores-Tovar (1999) e Sebastião \& Soares (1995) aplicam esta metodologia para estudar a dispersão de óleo no oceano.

Já Drago et al. (2001) desenvolveram um modelo 3D para analizar a dispersão de sólidos suspensos e poluentes conservativos lançados no ambiente aquático e seus efeitos no comportamento trófico. Sharma et al. (2001) apresentaram um novo modelo de transporte baseado no método tradicional de caracteristicas (MOC), utilizando o método de Runge-Kutta de quarta ordem para traçar o movimento de pacotes de volume predefinido, que são utilizados ao invés da concentração. Dias et al. (2001) usaram este método no estudo de processos de dispersão e tempo de residência na lagoa do Rio de Aveiro (Portugal).

O modelo do tipo "random flight" adotado para o cálculo da velocidade turbulenta tem sido aplicado com sucesso à estimativa de poluentes na atmosfera e mostra ser uma ferramenta simples e flexível no estudo de fluxos complexos turbulentos pois, sendo modelos lagrangeanos, permitem cálculos diretos de processos, como interações biológicas, ao longo de trajetórias. Este método permite uma economia substancial no tempo de computação e na informação a respeito do campo turbulento quando comparado com outras representações de $\mathbf{u}$ que incluem a dependência total no espaço (como uma série estocástica bidimensional de Fourier), e apresenta todos as variáveis necessárias para descrever a difusão turbulenta de uma partícula simples.

Este tipo de "random flight model" tem sido recentemente aplicado a diversos processos oceanográficos, tais como predição do movimento Lagrangeano (Falco et al., 2000; Ozgokmen 
et al., 2000 ), estudo da influência da turbulência na difusão (Dutkiewicz et al., 1993; Zambianchi \& Griffa, 1994) ou simulação do movimento de organismos(Cianelli et al., 2004).

Os resultados obtidos com o uso do IBM, reproduziram de maneira geral, o transporte e retenção larval da anchotíta Engraulis anchoita na PCSA. A seguir esses resultados serão discutidos.

\subsection{Influência do transporte de Ekman e da circulação no transporte e retenção larval}

Os resultados de retenção obtidos para a deriva de Ekman associada ao padrão de ventos da região, apresentam valores altos para todos os meses e áreas, por dois motivos. O primero, e principal, é pela baixa magnitude das velocidades superficiais geradas apenas pela tensão de cisalhamento do vento, as quais variam apenas entre 0 e $0,035 \mathrm{~ms}^{-1}$. Isso causa uma lenta dispersão das larvas, e evita uma rápida deriva em direção às áreas oceânicas, mesmo em situações favoráveis para que isso ocorra. A segunda razão é pelo transporte de Ekman ser direcionado para a costa, ou ao longo da mesma, durante boa parte do ano.

Os meses nos quais ocorrem as menores perdas, maio e junho, são justamente os meses nos quais há predominância de ventos do quadrante sul, ocasionados pela frequente passagem de sistemas frontais na região. Nesses meses, o transporte de Ekman é fortemente direcionado para a costa em todas as áreas, e a menor retenção observada ocorre por este fato: as larvas não são advectadas para a direção oceânica, mas em direção à costa. Pelas suposições adotadas na construção do modelo, um intenso transporte de Ekman em direção à costa pode não ser favorável à retenção ou a sobrevivência larval pois: as áreas mais costeiras, com profundidades menores que 20 metros, não foram consideradas áreas berçário; a condição de contorno adotada no modelo, na qual as larvas morrem ao atingirem a terra. Durante os meses de maio e junho houve um aumento da concentração larval nas regiões com profundidades menores que 20 metros.

A maior dispersão obtida foi para as larvas originadas na área 1, fato que parece estar diretamente relacionado à direção das correntes superficias geradas pela dinânica de Ekman nesta região, as quais são direcionadas para fora da costa na maior parte do ano, advectando as larvas para o oceano aberto. Esse padrão de circulação também é observado na área 2, cujas larvas apresentam a maior dispersão nos meses de primavera/verão, época na qual também ocorrem as menores retenções na área.

As larvas lançadas nas áreas 3 e 4 apresentam taxas de dispersão muito similares, assim como os padrões de retenção observados nessas áreas. Os meses com menor retenção são maio e junho, nos quais a deriva de Ekman direcionada à costa contribui para a adveção larval nessa direção. Ao longo de todo o ano há a ocorrência de larvas das áreas localizadas ao norte (1 e 2) na área 3, as quais são advectadas pelas correntes fluindo para o sul.

Já o padrão de retenção obtido com o modelo biológico alimentado pelas velocidades supeficiais provenientes do modelo hidrodinâmico, apresenta uma clara tendência sazonal, com os valores de retenção sendo minímos no início do verão, crescendo com a proximidade do outono e alcançando seus valores máximos durante esta estação. Esse padrão é 
fortemente influenciado pelas variações sazonais do sistema de Correntes e da Confluência Brasil-Malvinas, do campo de ventos e da circulação induzida pela descarga fluvial.

Sabe-se que tanto a CM quanto a CB apresentam uma variação sazonal da latitude na qual elas se separam da plataforma e da quebra de plataforma (Olson et al., 1988; Wainer et al., 2000; Souza \& Robinson, 2004). Nos meses de verão, há uma intensificação da influência da CB sobre a circulação na plataforma e, durante o inverno, da CM. A circulação dirigida pela descarga fluvial também apresenta uma variação sazonal, sendo mais marcante durante os meses de outono/inverno, épocas nas quais a descarga de água doce, ocasionada por uma maior precipitação na bacia hidrográfica do Rio da Prata e da Lagoa dos Patos, atinge seus maiores valores. A predominância dos ventos de sudeste reforça o transporte destas águas fluviais para o norte.

Os meses de outono e inverno são os que apresentam maior quantidade de larvas nas áreas berçário, com até $70 \%$ de organismos retidos. Os picos de concentração larval coincidem com os meses onde ocorre a maior incidência de ventos do quadrante sul, cujo efeito é adicionado ao gradiente de densidade, ao efeito da força de Coriolis, e à influência marcante da Corrente das Malvinas, o que resulta numa intensificação da corrente para nordeste. Esta intensificação ajuda a transportar os ovos de uma área berçário a outra e a mantê-los próximos a costa, já que o transporte resultante não é direcionado ao oceano. Ao mesmo tempo, é durante estes meses que ocorre a maior propagação da pluma do estuário do Rio da Prata para norte.

Durante o inverno ocorre a diminuição da intensidade da CB e o aumento da intensidade da CM, que passa a fluir até menores latitudes. Também há a formação de uma célula de circulação anticiclônica na desembocadura do estuário do Rio da Prata, pelo fato do estuário ser bem mais largo que o raio baroclínico de Rossby, enquanto a Lagoa dos Patos, por ser muito menor, exibe esta célula de circulação na plataforma continental, numa região próxima a sua desembocadura, durante meses com alta descarga fluvial (Soares, 2003). Essas feições contribuem para a recirculação da água e o aprisionamento larval.

Nessas estações as correntes próximas a costa, entre o Chuí e a desembocadura do Rio da Prata, apresentam velocidades muito pequenas, formando um importante centro de retenção larval. A existência desta área com correntes residuais fracas e a possível importância biológica da mesma já haviam sido propostas por Soares(2003). A utilização do modelo biológico acoplado ao hidrodinâmico tornou possível a quantificação desta importância para a alta concentração larval nestas regiões. As larvas nascidas nas áreas 2 e 3, justamente as que se beneficiam dessa zona de baixa hidrodinâmica, são as menos dispersas ao longo de todo ano.

Os meses de primavera e verão são os que apresentam as menores retenções. No verão, a CBM atinge seu ponto mais ao sul, o que reflete numa maior influência da CB na circulação sobre a plataforma, além das larvas não contarem com os mecanismos de transporte para norte gerados pela ação dos ventos sul e pelo deságue continental. Nessas estações, ocorre a predominância de ventos nordeste, favoráveis ao transporte para fora da costa, cujo efeito, somado ao de uma CB intensificada, resulta numa alta dispersão, cerca de $70 \%$ em janeiro e dezembro. As baixas descargas fluviais registradas, também não favorecem a geração de uma pluma forte o suficiente para vencer os ventos nordeste e se propagar para norte.

Embora este seja o padrão geral apresentado para toda a região, cada área apresenta um padrão distinto de comportamento. De uma certa forma, a alta sazonalidade da retenção, 
está muito influenciada pelos padrões de retenção das áreas 1 e 2, já que as áreas 3 e 4 não apresentam esta variação marcadamente sazonal.

As larvas originadas na área 1, são as mais dispersas ao longo de todo ano, da mesma forma que esta área é a que apresenta a menor retenção, com larvas na área somente no outono. A influência que a $\mathrm{CB}$ exerce sobre esta região da plataforma, gerando um forte fluxo direcionado para o sul durante todo o ano é responsável por esses valores. Somente durante o outono há mecanismos que retêm este fluxo, destacando-se a circulação induzida pelo vento e pela descarga fluvial. A maior quantidade de larvas retidas nessa área provém da área 2, mas há presença de larvas até da área 3, transportadas pelas correntes direcionadas para o norte durante o outono.

Os organismos lançados na área 2 são os que apresentam a retenção mais constante ao longo do ano, possivelmente porque as larvas desta área podem se beneficiar tanto do transporte direcionado para o norte, quando são transportadas para a área de retenção 1 , quanto para o sul, quando são retidas especialmente na área 3. Já o comportamento da área como berçário destes indivíduos, tem uma grande variação. Os meses do verão e da primavera são os que apresentam as menores retenções, enquanto os de inverno e outono apresentam as maiores. Os mesmos mecanismos atuantes na dispersão/retenção dos organismos da área 1, são os que atuam na área 2, o que pode ser confirmado pela origem das larvas aí retidas. Embora na maior parte do ano as larvas originadas na própria área sejam maioria, durante maio e junho, quando existe um vigoroso transporte para o norte, há um grande aumento da presença de larvas da área 3 e um leve aumento das da área 4, ao mesmo tempo que se observa uma diminuição de larvas da área 2, que são transportadas para a área 1. Durante o outono também observa-se uma tendência das larvas concentrarem-se na plataforma média, devido ao fluxo menos proeminente nessa área intermediária que tende a concentrar os organismos.

Os indivíduos da área 3 apresentam as maiores retenções ao longo do ano, especialmente no final de outono e início de inverno, quando a dispersão larval é bem próxima a zero, refletindo a importância da zona com correntes residuais fracas ao longo da costa nessa região, da circulação induzida pela descarga de água doce e da célula de recirculação do estuário do Rio da Prata, como mecanismos eficientes na retenção larval. O pico de retenção é deslocado para os meses de agosto e setembro, quando ocorrem as correntes mais fracas na área e a célula de recirculação na entrada do estuário. Durante a maior parte do ano as larvas da própria área são maioria. No final de primavera e início de verão, as larvas da área 2 têm as maiores presenças, devido às correntes direcionadas para sul e em maio, as larvas da área 4 são maioria. No outono e inverno, a maior retenção ocorre na plataforma média, em função das pequenas velocidades observadas sobre esta região e da convergência em torno da mesma. Nos meses de retenção màxima, a maior concentração de organismos dá-se nas áreas entre 20 a 100 metros de profundidade, reforçando a importância da célula de recirculação.

As larvas desovadas na área 4 são mais dispersas no verão/primavera, devido às correntes direcionadas para sudeste e com altas velocidades. No restante do ano, as correntes na área são mais fracas, o que suporta a retenção das larvas da própria área. A retenção larval na área 4 não apresenta sazonalidade, e é consideravelmente alta. As maiores concentrações ocorrem sobre a plataforma média, onde a convergência das correntes e as menores velocidades retêm as larvas. 


\subsection{Comparação dos dados obtidos com dados observa- cionais}

Na região estudada, diversos trabalhos foram desenvolvidos com base na distribuição do estoque desovante, presença de ovos e larvas na plataforma continental e suas relações com condições ambientais (Weiss et al., 1976; Weiss \& Souza, 1977; Hubold, 1982; Acuña \& Castello, 1986; Ciechomski \& Sanchez, 1988; Bakun \& Parrish, 1991; Vasconcellos, 1994; Lima \& Castello 1994 e 1995; Sanchez \& Ciemchomski, 1995; Muelbert \& Sinque, 1995; Busoli, 2001). A maior parte destes trabalhos trata da descrição de eventos específicos, sem a continuidade e repetição da amostragem na estação do ano e nas próximas. Especialmente para a região brasileira, a amostragem se torna esparça e os resultados a serem discutidos podem ser considerados preliminares, já que são baseados em um pequeno número de cruzeiros.

Cabe salientar que o presente estudo buscou delimitar os padrões de transporte e retenção larval, e, além do número de larvas lançadas não ser realístico, foi considerado que a desova ocorre com a mesma intensidade ao longo de todo o ano em toda a área de estudo, o que não corresponde à realidade. Desta forma, os resultados obtidos com o modelo podem ser contrastados com os resultados reais de maneira a buscar-se entender os mecanismos dominantes sobre a dispersão dos estágios iniciais dos peixes da região sem, contudo, reproduzir totalmente a realidade. Também é possível, utilizando-se de dados de concentração mensal de ovos e presença de adultos desovantes sobre a plataforma, estimar quais resultados obtidos pela modelagem podem ser observados em campo, o que facilitaria o planejamento de cruzeiros e amostragens para a região.

Os resultados obtidos quando foi utilizado somente o transporte de Ekman não foram satisfatórios para explicar os padrões de desova e de retenção larval observados para a anchoíta, já que, considerando-se apenas a velocidade de Ekman, todos os meses seriam altamente favoráveis à retenção larval. Os baixos valores apresentados pela deriva de Ekman são inadequados para representar o ambiente em que a anchoíta se desenvolve, ao levarmos em conta a intensa dinâmica que a região apresenta, como descrito no Capítulo 2 "Área de estudo". Os resultados obtidos com o modelo forçado pela deriva de Ekman não levam em conta dois dos principais mecanismos de transporte e retenção larval na regi ao: a circulação dirigida pela saída de água doce do Rio da Prata e da Lagoa dos Patos e a dinâmica do sistema de correntes da Confluência Brasil-Malvinas.

Já os resultados observados quando o modelo foi alimentado pela saída do modelo hidrodinâmico, parecem ser mais adequados para representar o comportamento dos ovos/larvas da anchoíta em seu ambiente. Nestes resultados foi observada a maior sazonalidade e, de uma maneira geral, os padrões encontrados correspondem aos assinalados pelos trabalhos desenvolvidos com dados observacionais, os quais registram maior desova durante o outono, inverno e primavera.

Lima \& Castello, em seu trabalho de 1995, enfatizaram a importância da dinâmica de Ekman na época de desova da anchoíta. Os autores assinalaram as condições favoráveis apresentadas durante o inverno e início de primavera ao transporte direcionado para a costa, como as principais responsáveis pelos padrões de desova da anchoíta. Como fatores secundários, 
apontaram o efeito do deságue continental e da entrada de água Sub-Antártica, na formação de uma maior estabilidade vertical na coluna dágua e no enriquecimento com nutrientes. Estes fatores seriam importantes para gerar um ambiente proprício ao desenvolvimento dos organismos, livre do efeito da turbulência e rico em alimentos.

Através dos resultados obtidos com o uso do modelo hidrodinâmico, pode-se verificar que a importância da descarga de água doce no sistema e a maior penetração das correntes frias e ricas em nutrientes vindas do sul, não se restringe à criação de um ambiente mais estratificado ou com maior disponibilidade de alimentos. A circulação baroclínica induzida pela descarga do Rio da Prata e da Lagoa dos Patos, constitui um eficiente mecanismo de retenção aos organismos, especialmente pela formação de células de recirculação, as quais aprisionam os organismos em áreas costeiras, e pela fomentação de correntes mais fracas próximo da desembocadura, que facilitam a permanência dos indivíduos nestas regiões. Também podese observar a importância das correntes da região, $\mathrm{CB}$ e $\mathrm{CM}$ e da CBM, no transporte e retenção larval ao longo da área estudada.

Estes giros de circulação, tanto causados por aporte fluvial tanto por outras forçantes, são reportados como importante mecanismo de retenção larval, na área de estudo e em outras regiões. Busoli (2001) assinalou que o deságue da Lagoa dos Patos força a formação de um giro anticiclônico sobre a plataforma, até a isóbata dos $100 \mathrm{~m}$, o qual causa o aprisionamento das larvas de anchoíta nesta região. Bakun et al. (1974), verificaram a formação de um giro anticiclônico na desembocadura do Rio Columbia, o qual retém parte das larvas de Engraulis mordax transportadas pela Corrente da California. Bartsch \& Coombs (2004) concluíram que uma grande concentração de ovos e larvas de Scomber scombrus observada ao norte de $51^{\circ} \mathrm{N}$ no Atlântico Norte Leste ocorria devido a um giro anticiclônico, trapeado sobre um banco.

Berasategui et al. (2004) encontraram ovos e larvas de Engraulis anchoita no estuário do Rio da Prata, durante cruzeiros realizados durante a primavera e o verão. Esse fato confirma a importância da célula de circulação existente no estuário, especiamente na primavera, para o transporte e retenção das larvas em áreas costeiras.

Comparando os padrões de retenção larval encontrados na área brasileira com os padrões de distribuição obtidos por Muelbert \& Sinque (1995), pode-se observar algumas semelhanças e algumas discrepâncias entre os resultados. Os meses nos quais os autores encontraram maior abundância de larvas foram os meses de primavera e verão, com concentrações de até 200 larvas $/ 100 \mathrm{~m}^{3}$ e 120 larvas $/ 100 \mathrm{~m}^{3}$, respectivamente. No outono e inverno foram registradas as menores concentrações, com máximo de 30 larvas $/ 100 \mathrm{~m}^{3}$. O modelo não reproduz estas concentrações observadas, o que pode ocorrer por diversos motivos. O primeiro é que a mesma quantidade de larvas é lançada todos os meses, e, as baixas concentrações larvais observadas pelos autores podem ocorrer não devido à mecanismos de transporte, mas a intensidade da desova naquela época do ano. Outro fato que deve ser ressaltado é que, apesar deste ser o trabalho que apresenta a maior periodicidade de amostragens na região, ainda assim reflete um número muito limitado de situações, com apenas 9 cruzeiros, os quais podem incluir o efeito de diversos mecanismos atuantes na população naquele, ou em algum ano anterior. Outro fator é a interpolação aplicada aos dados, a qual pode "mascarar" os resultados, especialmente quando há uma estação com uma concentração muito grande ou pequena. As larvas foram coletadas ao longo de uma camada de 200 metros de profundi- 
dade, e o modelo só reproduz a distribuição das larvas que se encontram na superfície. O último fator pode ser o modelo hidrodinâmico utilizado, o qual reproduziu bem as principais feições encontradas na área, mas a circulação de pequena escala não parece estar satisfatoriamente resolvida. A região de estudo é caracterizada por padrões complexos de circulação, com diversos braços de correntes direcionados para dentro e para fora da costa, aparecendo simultaneamente a vórtices de mesoescala e as feições costeiras de pequena escala. Esses padrões de circulação, como o vórtice anticiclônico na desembocadura da Lagoa dos Patos ou a Corrente de Rio Grande, não estão resolvidos. Deve-se ressaltar que os dados do modelo são integrados a cada três dias, o que retira a possibilidade da resolução de feições com uma escala temporal menor.

De qualquer forma, alguns padrões apresentados por ambos os dados podem ser comparados. Durante o verão, a maior concentração larval obtida com coletas foi no sul da área de estudo, na região da área 2, e poucas, ou nenhuma larva, foi detectada na área 1. Esse resultado concorda com os obtidos com o modelo, que mostram que, durante o verão em média $6,1 \%$ de larvas são retidas na área 2 e nenhuma larva é retida na área 1.

Durante o outono, há grandes concentrações de larvas ao sul e norte da área 1 e norte da área 2. A concentração larval encontrada ao norte da área 1 pode ocorrer devido a diversos fatores, como: transporte para o norte por uma corrente costeira não resolvida pelo modelo hidrodinâmico; transporte para sul de larvas provenientes de regiões mais ao norte, no estado de Santa Catarina. Já concentrações encontradas ao sul de $32^{\circ}$, concordam com as obtidas pelo modelo, em que ocorre uma grande concentração larval durante o outono na área 1 e na área 2. É relevante observar que as distribuições longitudinais também concordam com os dados observacionais. Nesses pode ser observada, ao longo da costa na área 1, uma concentração constante, apesar de não muito alta e um foco com maiores concentrações sobre a plataforma externa. Já nos dados obtidos pelo modelo aparecem, durante o outono, picos de concentração larval nestas duas regiões da plataforma. Na área 2 os dados do modelo mostram um aumento da concentração larval sobre plataforma externa nesta época, justamente onde aparecem focos de larvas nos dados observacionais.

Durante o inverno é registrada nos dados de campo a presença de larvas sobre toda a plataforma da área 1 e 2, especialmente ao sul da primeira e norte da segunda. Estas concentrações não foram reproduzidas pelo modelo para a área 1. Já a área 2 apresentou, segundo o modelo, uma média de retenção de 10,6\% nesta estação, mas a distribuição longitudinal dos organismos modelados não é similar à dos coletados. Na primavera, novamente não há uma similaridade nos dados, especialmente porque, pelos resultados de modelagem, não há presença de larvas na área 1 . Na área 2, a modelagem resultou numa retenção média de $5,9 \%$ e, a distribuição longitudinal dos dados de campo concorda com a dos modelados, onde maiores concentrações são exibidas sobre a plataforma interna.

Os resultados obtidos neste trabalho também não concordam com grande parte dos resultados obtidos por Busoli (2001), o qual registrou fluxos de ovos e larvas predominantemente para o norte, nas regiões 1 e 2, durante os meses de outubro de 1987 e setembro de 1988. Os resultados mostram-se diferentes especialmente porque os campos de velocidades utilizados nos dois trabalhos apresentam-se bem distintos. O autor utilizou-se de um campo de velocidades geostrófico para calcular o fluxo de larvas na plataforma, a partir do qual observou o desenvolvimento de células de recirculação com um fluxo geral perpendicular a PCGU na 
primavera de 1987 e um fluxo paralelo e ao longo da plataforma, direcionado para NE, no inverno de 1988. Estes padrões são muito diversos dos observados no presente trabalho. Como já dito anteriormente, o modelo hidrodinâmico utilizado no presente trabalho não reproduziu bem feições de pequena escala, as quais foram detectadas pelo autor. Além disso, o cálculo de velocidades geostróficas possui diversas limitações (Busoli, 2001), e as velocidades estimadas podem não refletir totalmente a circulação da região. Por fim, os dados de ictioplâncton foram amostrados ao longo da coluna d'água, até 200 metros de profundidade, e os resultados deste trabalho referem-se somente à camada superficial.

Já na região argentina, os resultados obtidos concordam em grande parte com o trabalho de Sanchez \& Ciechomski (1995), no qual os autores observaram que parte das larvas nascidas durante o outono e inverno são advectadas em direção ao norte, onde elas se desenvolvem em águas relativamente mais quentes e que larvas eclodidas na primavera e verão, na província de Buenos Aires, são retidas nesta área. Os resultados do modelo mostram esse transporte em direção ao norte, sobretudo nos meses do outono, quando as larvas nascidas na área 3 chegam a alcançar a área 1 e as da área 4 são levadas até a costa uruguaia. Durante os meses de início de primavera e final de verão ocorre uma grande retenção dos organismos nascidos na área 4 em sua própria origem, mas nos meses de final de primavera e início de verão a retenção não é tão eficiente, sendo grande parte das larvas desta região transportadas pelas correntes costeiras e pela CBM.

Considerando trabalhos que trazem a posição dos estoques desovantes e a concentração de ovos ao longo do ano, pode-se estimar quais resultados de retenção larval gerados pela modelagem numérica poderiam ser de fato observados. Lima \& Castello (1995) apresentaram gráficos da distribuição da biomassa de anchoíta para as seguintes épocas: agosto 1980, outubro/novembro de 1982, outubro de 1987, setembro de 1988 e janeiro de 1990. Não há nenhum dado apresentado para a época de outono. Os autores encontraram a maior concentração do estoque desovante ao longo de toda a região $\left(32^{\circ} \mathrm{S}-34^{\circ} \mathrm{S}\right)$ durante o mês de setembro, seguido por concentrações levemente menores em outubro. Em janeiro foram registradas as menores concentrações e em agosto o estoque ocupava posições principalmente ao sul dos $33^{\circ}$ S. Sanchez \& Ciechomski (1995), apresentaram um estudo das áreas berçário e de desova de espécies de peixes pelágicos na plataforma continental argentina e adjacências, realizado com base em 5275 amostras coletadas durante 116 cruzeiros, os quais foram realizados entre 1966 e 1994 cobrindo a região entre $34^{\circ} \mathrm{S}$ a $55^{\circ} \mathrm{S}$.

Segundo a ocorrência de estoques desovantes na área apresentadas por Lima \& Castello (1995), os resultados de porcentagens de larvas provenientes da área 1, observados para os meses de janeiro e de agosto a novembro poderiam ocorrer, pois haveria desova na região. Segundo os resultados de Sanchez \& Ciechomski (1995), para a concentração de ovos sobre a plataforma na área 2, os meses que apresentam concentrações elevadas (maiores que 1000 ovos $/ 10 m^{2}$ em pelo menos uma estação dentro da região) são os de junho a outubro, sendo este último o que apresenta as maiores concentrações. Em fevereiro, março e maio foram registradas pequenas concentrações, até 100 ovos $/ 10 m^{2}$. Os outros meses não apresentam resultados. Para a área 3, há uma marcante presença de ovos (mais que 1000/10 $\mathrm{m}^{2}$ ) em abril, maio, julho e de agosto a dezembro. Finalmente, na área 4, as maiores concentrações de ovos (mais de $1000 / 10 m^{2}$ ) podem ser observadas em janeiro, maio e de outubro a dezembro. 


\subsection{Possibilidades de sobrevivência}

Nesta seção será feita uma breve discussão sobre as chances de sobrevivência das larvas retidas durante as quatro estações do ano, com base em dados de salinidade, temperatura e disponibilidade de alimento na região.

\subsubsection{Salinidade}

O gênero Engraulis é um dos clupeiformes mais largamentes distribuídos, sendo encontrado em águas costeiras de várias plataformas continentais e grandes amplitudes de temperatura e salinidade. Os subadultos da anchoíta toleram salinidades baixas, razão pela qual podem ser observados até mesmo em estuários (Brandhorst \& Castello, 1971). Já o desenvolvimento dos ovos da anchoíta é limitado pela salinidade, pois os mesmos não se desenvolvem em salinidades inferiores a 23 (Ciemchomski \& Sanchez, 1984).

Os dados de salinidade observados sobre a plataforma foram obtidos do World Ocean Atlas (WOA). Como os dados são espaçados a cada $1^{\circ}$, na interpolação algumas regiões podem apresentar valores sub ou superestimados. De uma maneira geral, a área apresenta salinidades adequadas para o desenvolvimento dos ovos da anchoíta, salinidades acima de 23. A excessão é a área 1, onde a salinidade ao redor da desembocadura da Lagoa dos Patos atinge valores baixos durante todas as épocas do ano.

Este resultado não é confirmado por outros trabalhos desenvolvidos na região, segundo os quais toda a plataforma é adequada ao desenvolvimento dos ovos durante todo o ano. No trabalho de Piola et al. (2001), tem-se a distribuição de temperatura e salinidade para a plataforma continental da área de estudo, durante o inverno e o verão, e os resultados exibem salinidades sempre acima dos 23, mesmo nas regiões próximas às desembocaduras do Rio da Prata e da Lagoa dos Patos. Piola et al. (2005) estudaram a influência da descarga do rio La Plata na plataforma continental adjacente, utilizando dados hidrográficos coletados desde 1950 e encontraram salinidades mínimas de 25 , em torno dos $36^{\circ} \mathrm{S}$, sendo que a salinidade da maior parte dos dados observacionais encontra-se em torno dos 33. Soares (2003) simulou, através de modelagem numérica, a circulação na região. No experimento considerando todas as forçantes, descarga fluvial, marés, ventos e CB, encontrou valores de salinidade acima dos 23 para toda a região da plataforma, exceto para uma área muito próxima a desembocadura do Rio da Prata (área 3). Isso foi observado mesmo durante o outono, onde ocorre a maior expansão da pluma fluvial. Lima et al. (1995), fizeram uma caracterização do ambiente oceanográfico no sul do Brasil, com base em dados do US National Climatic Center e de três cruzeiros hidrográficos. Os autores encontraram durante as três estações estudadas, verão, inverno e primavera, valores de salinidade sempre maiores que 28 , mesmo na região da desembocadura da Lagoa dos Patos.

Desta forma, pode-se esperar que todas as estações do ano possuam salinidades adequadas ao desenvolvimento dos ovos de anchoíta na região, salvo a área 1, onde a entrada de água doce da Lagoa dos Patos pode vir a gerar uma área de baixa salinidade sobre a plataforma, imprópria para a sobrevivência larval. 


\subsubsection{Temperatura}

A anchoíta pode ser encontrada sobre uma ampla distribuição de temperaturas. Hansen et al. (2001) estudaram a relação entre a distribuição espacial do estoque patagônico da anchoíta e temperaturas da água do final da primavera ao início do outono, e verificaram que as temperaturas nas quais elas se encontram variaram de 8,5 a $16,5^{\circ} C$, sendo que os índicios da presença de anchoitas em águas acima de $14^{\circ} \mathrm{C}$ foram encontrados durante a noite. Os autores assinalaram como limites de temperatura superficial para a distribuição da anchoíta dos 11 aos $17^{\circ} \mathrm{C}$, com uma faixa preferencial dos 12.5 aos $16^{\circ} \mathrm{C}$, mas sem um valor específico predileto. Castello (1997), durante diversos cruzeiros realizados na plataforma continental sul do Brasil, encontrou anchoitas adultas habitando águas entre os 9,5 e $21,7^{\circ} \mathrm{C}$. Enquanto a distribuição do estoque adulto não mostra uma estreita relação com a temperatura, o desenvolvimento durante o estágio embrionário e o tempo de eclosão das larvas são largamente controlados por ela (Ciechomski e Sanchez, 1984).

Os campos de temperatura obtidos do WOA são satisfatórios, já que a temperatura é uma variável bem amostrada na área de estudo e apresenta grandes variações . Os valores apresentados concordam com os observados por Lima et al. (1995) e por Piola et al. (2001).

Assim tem-se que, durante o verão, ocorrem as maiores temperaturas sobre a plataforma, cerca de $24^{\circ} \mathrm{C}$ na área 1 , e durante o inverno as menores, cerca de $9^{\circ} \mathrm{C}$ na área 4 . Este valor coincide com o apontado por Sanchez (1986) como sendo uma barreira física para a desova. Experimentos realizados com outras espécies de clupeídeos demonstraram que a taxa de crescimento diária das larvas pode variar entre 0,3 e $1 \mathrm{~mm}$ por dia, só ultrapassando os 0,7 $m m$ quando as temperaturas utilizadas foram superiores a $26^{\circ} \mathrm{C}$.

De uma maneira geral, a temperatura não parece limitar a sobrevivência dos ovos e larvas da espécie, mas tem papel fundamental no seu crescimento. Para um organismo marinho planctônico, sujeito a inúmeros riscos tais como dispersão, inanição e predação, crescer rapidamente e ganhar mobilidade para superar estes riscos pode ser o diferencial entre viver e morrer, então, temperaturas mais elevadas podem ser fundamentais para um recrutamento bem sucedido. Pode-se observar, pelos resultados de Sanchez \& Ciechomski (1995) citados anteriormente, que a área 4, sobre a qual aparecem as menores temperaturas, não apresenta concentrações significativas de ovos durante os meses de inverno, mostrando novamente que a estratégia reprodutiva da espécie está intimamente ligada aos padrões bióticos observados na região.

O modelo obteve para esta área valores altos de retenção durante o inverno. Estas larvas seriam as que apresentariam o desenvolvimento embrionário e larval mais lento, estando sujeitas por mais tempo a altas taxas de mortalidade.

\subsubsection{Disponibilidade de alimento}

Um dos principais fatores limitantes para o desenvolvimento das larvas, especialmente após o esgotamento do saco vitelínico, é a disponibilidade de alimento quando a larva necessita de alimentação exógena (Freire, 1995). As larvas de Engraulis anchoita da região do sul do Brasil são essencialmente zooplanctófagas, alimentando-se de nauplios, copepoditos, copépodos, ovos de invertebrados e tintínideos e são oportunistas, alimentando-se esporadicamente de 
elevado número de um mesmo item alimentar que estiver abundantemente disponível (Freire, 1995). Esta característica oportunista também é apresentada pelos adultos da espécie, que mesmo sendo normalmente consumidores de plâncton podem predar grandes quantidades de zooplâncton gelationoso, como os membros dos filos Cnidaria, Ctenophora e Urochordata, quando a disponibilidade destes no meio é alta (Miazan et al., 2001). Durante as primeiras fases das larvas da maioria dos peixes marinhos, há uma tendência ao hábito eurifágico, em que a larva se alimenta de tintinídeos, fitoplâncton, larvas de moluscos e ciliados (Freire, 1995).

Desta forma, o conhecimento dos padrões de distribuição de alimento é essencial para se discutir a sobrevivência das larvas retidas. Além dos padrões de distribuição de zooplâncton para a região, são descritos os padrões sazonais de clorofila $a$ e taxas de produção primária, por esses serem muito bem amostrados para essa região do Atlântico, e, pela produção primária na superfície do oceano ser a base para quase todas as cadeias alimentares marinhas (Valentin, 1984; Doney et al., 2001).

Altas concentrações de clorofila $a$ e de taxas de produção primária ocorrem na costa do Brasil. Odebrecht \& Garcia (1996), baseados em dados de 6 cruzeiros, calcularam a média anual de produção primária particulada, resultante em $160 \mathrm{gcm}^{-2} a \mathrm{no}^{-1}$. Taxas de alta produtividade resultam principalmente do transporte para norte da Água Subantártica, rica em nutrientes, da descarga fluvial e da ressurgência da Água Subtropical. Os maiores valores são encontrados durante o final de inverno e início de primavera, quando os altos valores de clorofila a são relacionados à entrada de nutrientes da Água Subantártica e descarga fluvial, associados com a estabilização da coluna d'água e enriquecimento de nutrientes (Ciotti et al., 1995). Durante o verão, os baixos valores de clorofila a ocorrem devido à limitação de nutrientes causada pelas águas oligotróficas transportadas pela CB.

Brandini et al. (2000) estudaram a distribuição horizontal e vertical da clorofila $a$ no Atlântico Sudoeste com base em 3 cruzeiros que cobriram a área de estudo em três anos consecutivos. Segundo os autores, zonas com alta produção de clorofila $a\left(>1 \mu g l^{-1}\right)$ estiveram presentes nos três verões, sendo uma destas áreas a zona da CBM. Ao contrário da maioria das frentes oceânicas, onde a clorofila $a$ se acumula em pequenas bandas, na CBM concentrações elevadas de clorofila $a$ estão associadas não só às frentes conhecidas, mas a largas áreas homogêneas entre elas.

Garcia et al. (2004), utilizaram 60 meses de dados de imagens SeaWIFS (Sea-viewing Wide Field-of-view Sensor) para investigar a variabilidade temporal e espacial das concentrações de clorofila $a$ na CBM. Os autores encontraram um pico de clorofila $a$ na plataforma continental da Argentina durante os meses de verão e na PCGU no final do inverno, relacionando esta diferença temporal do pico de produtividade aos processos estabilizadores da coluna d'água em ambas as regiões. Ainda segundo os autores, a CM também apresentou um sinal anual de anomalia na clorofila $a$, onde os picos de verão provavelmente estaõ associados com a menor turbulência das águas neste período e à mistura com águas ricas em clorofila $a$ da plataforma.

Além da influência marcante do sistema de correntes $\mathrm{CM}$ e $\mathrm{CB}$, da $\mathrm{CBM}$ e do aporte de água doce, as frentes formadas nesta área também desempenham um papel muito importante na retenção de organismos. Estas zonas frontais são caracterizadas por uma alta produção biológica. 
O zooplâncton costeiro e marinho da área é representado por diversas espécies de diferentes famílias. A composição das espécies e a distribuição temporal e espacial dos organismos zooplanctônicos são diretamente relacionados à dominância de diferentes massas d'água sobre a PCGU. Os maiores valores de biomassa zooplanctônica estão relacionados à influência da Àgua Subantártica e a Água Costeira, com uma importante contribuição do deságue da Lagoa dos Patos e do Rio da Prata durante os meses de inverno. Os maiores valores de carbono ocorrem durante a primavera e o verão (maiores que 98,47 $\mathrm{mgCm}^{-3}$ ), e valores altos de distribuição de biomassa zooplanctônica podem ser observados no verão e no outono/inverno (Montú et al., 1996).

Freire (1995), estudando a alimentação de larvas de anchoíta na PCGU, concluiu que a região é propícia a alimentação das larvas, com incidência média de alimento de $45 \%$. A autora aponta que o inverno parece ser a época mais favorável à alimentação. Já os dados apresentados pelos trabalhos de Montú et al., 1996 e de Odebrecht \& Garcia (1996), mostram que a maior abundância de alimentos para as larvas sobre toda a plataforma é a primavera. As larvas retidas nesta época têm grande chance de encontrar alimento disponível, e condições de estabilidade nos nínveis superiores da coluna d'água, que possibilitam uma maior chance de encontro com o alimento, sem dispersá-lo. O verão também se mostra uma estação promissora em termos alimentares, com grande quantidade de zooplâncton disponível nas áreas 1 e 2, e grandes quantidades de clorofila a próximo as áreas 3 e 4 . O maior inconveniente seria a alta turbulência associada a $\mathrm{CB}$, que pode dificultar o encontro presa-alimento. $\mathrm{O}$ outono, apesar de ser a estação que menos se destaca em termos de disponibilidade alimentar, também apresenta uma quantidade significativa de alimento, especialmente pelos elevados valores de biomassa zooplanctônica observados sobre a plataforma (Montú et al., 1996).

De acordo com os dados e trabalhos apresentados, a disponibilidade de concentrações significativas de clorofila $a$ durante todo o ano sobre a plataforma continental, os altos valores de biomassa do zooplâncton disponíveis tornam todas as estações favoráveis a alimentação das larvas que ficarem retidas nas áreas berçário. 


\section{Capítulo 7}

\section{Conclusões e Sugestões}

Um IBM foi desenvolvido para simular os estágios iniciais de vida da anchoíta Engraulis anchoita, na plataforma continental sul do Brasil, do Uruguai e norte da Argentina. As conclusões deste trabalho são:

- O modelo desenvolvido mostrou-se satisfatório para simular o transporte e a retenção de ovos e larvas de Engraulis anchoita na PCGU e PCAU. Esta ferramenta mostrou ser de extrema utilidade para estudos de recrutamento de populações pesqueiras, especialmente se sua utilização for conjunta com a de dados observacionais.

- A utilização dos dados da deriva de Ekman associados ao padrão de vento na região para alimentar o IBM, não foi suficiente para representar adequadamente o padrão de retenção larval observado na região, o que leva a identificar a importância de outros processos oceanográficos atuantes no transporte e retenção destes indivíduos.

- Os padrões de distribuição obtidos com a utilização da saída do modelo hidrodinâmico representa os padrões observados em outros trabalhos para a retenção na região: maiores valores durante outono, inverno e primavera e menores durante o verão.

- A circulação baroclínica induzida pela descarga do Rio da Prata e da Lagoa dos Patos constitui um eficiente mecanismo de retenção dos organismos, especialmente pela formação de células de recirculação, as quais aprisionam os organismos em áreas costeiras, e a fomentação de correntes mais fracas próximo a desembocadura, que facilita a permanência dos indivíduos nestas regiões.

- Há um intenso transporte de larvas entre as áreas estudadas. Durante o outono, este transporte é direcionado predominantemente para o norte, e durante o verão é fortemente direcionado para o sul.

- As maiores concentrações larvais são observadas nas áreas berçário (entre 20 e 350 metros de profundidade), especialmente sobre a plataforma média, entre 100 e 200 metros.

- Considerando toda a área, diversos meses apresentaram uma baixa retenção, até $30 \%$. Alguns desses meses estão relacionados à períodos nos quais não ocorre desova. 
- Apesar das principais feições da região estarem bem representadas pelo modelo hidrodinâmico utilizado, algumas feições de pequena escala, como vórtices e braços de correntes, não foram bem resolvidos o que levou a impossiblidade de reproduzir alguns mecanismos de retenção.

- Em relação às condições ambientais para o desenvolvimento das larvas retidas, os três fatores analisados, temperatura, salinidade e estimativa de disponibilidade de alimento, demonstraram que todas as áreas apresentam condições favoráveis á sobrevivência e crescimento destas larvas.

Os dados obtidos vieram a ajudar a compreensão dos fenômenos envolvidos no transporte e retenção de ovos e larvas na plataforma continental do sul do Brasil, Uruguai e norte da Argentina. Os resultados e conclusões deste trabalho podem vir a ajudar o planejamento de futuros estudos do ictioplâncton na região, especialmente escolhas de épocas e locais mais adequados para amostragens em cruzeiros. Também salientou-se a imensa importância de um trabalho conjunto dos três países, Brasil, Uruguai e Argentina, na criação de diretrizes para o manejo dos recursos pesqueiros, tendo em vista o intenso fluxo biológico que ocorre na região.

Apesar dos avanços obtidos neste trabalho, vários aspectos podem ser melhorados ou precisam de estudos mais detalhados. Algumas sugestões para futuros trabalhos seriam:

- Utilização de um modelo hidrodinâmico com uma resolução espacial e temporal mais refinada, a qual possa reproduzir melhor as feições de pequena escala largamente ocorrentes na região.

- Criação de um módulo no modelo biológico para o acoplamento de dados de temperatura e salinidade, para simular a limitação por salinidade e o crescimento influênciado pela temperatura.

- Implementação de um modelo de transporte de partículas tridimensional, onde possam ser avaliados o efeito da flutuabilidade dos ovos e larvas, da produndidade de transporte e de processos oceanográficos tais como frentes, subsidência e ressurgência, no transporte e retenção dos estágios iniciais do ciclo de vida de peixes.

- Acoplamento de um modelo Nutriente-Fitoplâncton-Zooplâncton (Nutrient-PhytoplanktonZooplankton - NPZ) ao modelo hidrodinâmico para examinar a dinâmica do plâncton na região. Utilizar estes dados de alimento disponível como entrada para um módulo de alimentação larval no IBM. 


\section{Capítulo 8}

\section{Referências Bibliográficas}

Aceituno, P. 1988. On the functioning of the Southern Oscillation in the South American sector. Part I: Surface climate. Monthly Weather Review, 116, 505-524.

Adlandsvik, B.; A. C. Gundersen; J. K. H. Nedreaas; A. Stene \& O. T. Albert. Modelling the advection and diffusion of eggs and larvae of Greenland halibut (Reinhardtius hippoglossoides) iin the north-east Artic. Fisheries Oceanography, 13:403-415.

Allain, G.; P. Petitgas; P. Grellier \& P. Lazure. 2003. The selection process from larval to juvenile stages of anchovy (Engraulis encrasicolus) in the Bay of Biscay investigated by Lagrangian simulations and comparative otolith growth. Fisheries Oceanography, 12(4/5):407418.

Bakun, A.; D. R. McLain \& F. Mayo. 1974. The mean annual cycle of coastal upwelling off western North America as observed form surface measurements. Fisheries Bulletin U.S., $72: 843-844$.

Bakun, A. 1996. Patterns in the Ocean. Ocean Processes and marine population dynamics. La Paz, California Sea Grant College System, National Oceanic and Atmospheric Adminstration in cooperation with Centro de Investigaciones Biológicas del Noroeste. 323 p.

Bakun, A. \& R. H. Parrish. 1991. Comparative studies of coastal pelagic fish reproductive habitats: the anchovy (Engraulis anchoita) of the southwestern Atlantic. ICES Journal of Marine Science, 48:343-361.

Bartsch, J. \& S. H. Coombs. 2004. An individual-based model of the early life history of makerel (Scomber scombrus) in the eastern North Atlantc, simulating transport, growth and mortality. Fisheries Oceanography, 13(6):365-379.

Batchelder, H. P.; C. A. Edwards \& T. M. Powell. Individual-based models of copepod populations in coastal upwelling regions: implications of physiologically and environmentally influenced diel vertical migration on demographic success and nearshore retention. Progress in Oceanography, 53:307-333. 
Baumgartner, T. R.; A. Soutar \& V. Ferreira-Bartrina. 1992. Reconstruction of the past history of Pacific sardine and northern anchovy populations over the past two millenia from sediments of the Santa Barbara Basin, California. CalCOFI Reports, 33:24-40.

Berasategui, A. D.; E. M. Acha \& N. C. Fernández Araoz. 2004. Spatial patterns of ichthyoplankton assemblages in the Río de la Plata Estuary (Argentina - Uruguay). Estuarine, Coastal and Shelf Science, 60:599-610.

Brandhorst, W. \& J. P. Castello. 1971. Evaluación de los recursos de anchoíta (Engraulis anchoita), frente a Argentina y Uruguay. I. Las condiciones oceanográficas, sinopsis del conocimento actual sobre la anchoíta y plan para su evaluación. Proyecto de Desarrollo Pesquero. Serie Informes Técnicos, Mar del Plata, 29:1-19.

Brandini, F. P.; D. Boltovskoy; A. Piola; S. Kocmur; R. Röttgers; P. C. Abreu \& R. M. Lopes. 2000. Multiannual trends in fronts and distribution of nutrients and chlorophyll in the southwestern Atlantic (30-62 ${ }^{\circ}$ S). Deep-Sea Research, Part I, 47:1015-1033.

Broekhuizen, N.; J. Oldman \& J. Zeldis. 2003. Sub-grid-scale differences between individuals influence simulated phytoplankton production and biomass in a shelf-sea system. Marine Ecology Progress Series, 252:61-76.

Busoli, R. O. 2001. Transporte e retenção de ovos e larvas de Engraulius anchoita na plataforma continental sul do Brasil. Dissertaç ao de Mestrado. Fundação Universidade Federal do Rio Grande, Departamento de Oceanografia. 78 p.

Campos, E. J. D.; J. A. Lorenzzetti; M. R. Stevenson; J. L. Stech \& R. B. Souza. 1996. Penetration of waters from the Brazil-Malvinas confluence region along the South American contiental shelf. Geophysical Research Letters, 26(14):2061-2064.

Castello, J. P. 1985. La ecologia de los consumidores del estuario da Lagoa dos Patos, Brasil. In: Yañes-Arancibia, A. (ed.) Fish Community Ecology in Estuaries and Coastal Lagoons: Towards an Ecosystem Integration. Mexico City, UNAM Press. P. 383-406.

Castello, J. P.; M. Haimovici; C. Odebrecht \& C. M. Vooren. 1996. The Continental Shelp and Slope. In: Seeliger, U.; C. Odebrecht \& J. P. Castello (eds.) Subtropical Convergence Environments, the Coast and Sea in the Southwestern Atlantic. Berlin, Springer-Verlag. P. 183-196.

Castello, J. P. 1996. A Anchoita (Engraulis anchoita, Engraulididae, Pisces) no Sul do Brasil. Tese de Doutorado. Fundação Universidade Federal de Rio Grande, Departamento de Oceanografia, 84 p.

Castro Filho, B. \& L. B. Miranda. 1998. Physical oceanography of the western Atlantic continental shelf between $4^{\circ} \mathrm{N}$ and $34^{\circ} \mathrm{S}$. In Brink, K. \& A. Robinson (eds.) The Sea - The Global Coastal Oceans Volume 10. Nova York, John Wiley \& Sons, Inc. P. 209-251 
Cianelli, D.; M. R. D’Alcalà; V. Saggiomo \& E. Zambianchi. 2004. Coupling mixing and photophysiological response of Antartic plankton: a Lagrangian approach. Antartic Science, 16(2):133-142.

Ciechomski, J. D. \& R. P. Sanchez. 1984. Field estimates of embryonic mortality of Southwest Atlantic anchoy Engraulis anchoita. Meeresforsh., 30(3):172-187.

Ciechomski, J. D. \& R. P. Sanchez. 1988. Analisis comparativo de las estimaciones de biomassa de la anchoita (Engraulis anchoita) en el Atlantico sudoccidental en diferentes anos y con distintas metodologias. Publicaciones de la comissioon tecnica mixta del frente maritimo, 4:117-131.

Ciotti, A. M. C.; C. Odebrecht; G. Fillmann \& O. O. Möller. 1995. Freshwater outflow and subtropical convergence influence on phytoplankton biomass on the southern Brazilian continental shelf. Continental Shelf Research, 15:1737-1756.

Cousseau, M. B. \& R. G. Perrotta. 1998. Peces marinos de Argentina. Mar del Plata, Instituto Nacional de Investigación y Desarrollo Pesquero. 163 p.

Crowder, L. B.; J. A. Rice; T. J. Miller \& E. A. Marschall. 1992. Empirical and Theoretical Approaches to Size-Based Interactions and Recruitment Variability in Fishes. In: DeAngelis \& D.L., Gross, L.J (eds.) Individual-based models and approaches in ecology. Population, communities and ecosystems, Nova York, Chapman and Hall, Inc. P. 237-255.

Cury, P. \& C. Roy. 1989. Optimal environmental window and pelagic fish recruitment success in upwelling areas. Canadian Journal of Fisheries Aquatic Sciences, 46:670-680.

Cushing, D. H. 1988. Marine Ecology and Fisheries. Cambridge, Cambridge University Press. 278 pp.

Davis, T. L. O. \& V. D. Lyne. 1994. Dispersal of the larval stage of Southern Bluefin Tuna Thunnus maccoyii, in the East Indian Ocean. In: Sammarco P. W. \& M. L. Heron (eds.) The Bio-Physics of Marine Larval Dispersal. Washington, American Geophysical Union. P. $137-148$.

DeAngelis, D.L. \& L. J. Gross. 1992. Individual-based models and approaches in ecology. Population, communities and ecosystems. Nova York, Chapman and Hall, Inc. 525 p.

De Vries, T. J. \& W. G. Pearcy. 1982. Fish debris in sediments of the upwelling zone off central Peru: A late Quarternary record. Deep-Sea Research, 28:87-109.

Dias, J. M.; J. F. Lopes \& I. Dekeyser. Lagrangian transport of particles in Ria de Aveiro lagoon, Portugal. Physics and Chemistry of the Earth Part B-Hydrology Oceans and Atmosphere, 26:721-727.

Doney, S. C.; I. Lima; K. Lindsay; J. K. Moore; S. Dutkiewicz; M. A. M. Friedrichs \& R. 
J. Matear. 2001. Marine Biogeochemical Modeling: Recent advances and future challenges. Oceanography 14(4):93:107.

Drago, M.; B. Cescon \& L. Iovenitti. 2001. A three-dimensional numerical model for eutrophication and polluant transport. Ecological Modelling, 145(1):17-34.

Dutkiewicz, S.; A. Griffa \& D. B. Olson. 1993. Particle Diffusion in a Meandering Jet. Journal of Geophysical Research, 98(C9):16487-165000.

Egbert, G. D.; A. F. Bennet \& M. G. G. Foreman. TOPEX/POSEIDON tides estimated using a global inverse model. Journal of Geophysical Research, 99-24821-24852.

Ekau, W. 1998. Comparative growth analysis of Engraulis anchoita from southern Brazil . Archive of Fishery and Marine Research, 46(1):1-17.

Falco, P.; A. Griffa; P.M. Poulain \& E. Zambianchi. 2000. Transport Properties in the Adriatic Sea as Deduced from Drifter Data. Jounal of Physical Oceanography, 30:2055-2071.

Forbes, C. \& D. Garrafo. 1988. A note on the mean seazonal transport on the Argentinian shelf. Journal of Geophysical Research, 93(C3):2311-2319.

Framinan, M. \& Brown, O. 1996. Study of the Rio de La Plata turbidity front, part I: spatial and temporal distribution. Continental Shelf Research,16(10):1259-1282.

Freire, K. M. F. 1995 Alimentação de larvas de Engraulis anchoita (Teleostei: Engraulidae) na Plataforma Continental do Rio Grande do Sul, Brasil. Tese de Mestrado. Fundação Universidade Federal do Rio Grande, Departamento de Oceanografia. 74 p.

Garcia, A. M.; J. P. Vieira \& K. O. Winemiller. 2001. Dynamics of the shallow-water fish assemblage of the Patos Lagoon estuary (Brazil) during cold and warm ENSO episodes. Journal of Fish Biology, 57.

Garcia, C. A. E. 1997. Physical Oceanography. In: U. Seeliger, C. Odebrecht \& J. P. Castello (eds.). Subtropical Convergence Environments: The Coast and Sea in the Southwestern Atlantic, Berlin, Spring-Verlag. P. 94-96.

Garcia, C. A. E.; Y. V. B. Sarma; M. M. Mata \& V. M. T. Garcia. 2004. Chlorophyll variability and eddies in the Brazil-Malvinas Confluence region. Deep-Sea Research Part II, 51:159-172.

Garcia-Martinez, R. \& H. Flores-Tovar. 1999. Computer modeling of oil spill trajectories with a high accuracy method. Spill Science 69 Technology Bulletin, 5:323-330.

Griffa, A. Applications of stochastic particle models to oceanographic problems. In: Adler, R. J.; P. Muller \& B. L. Rozovskii (eds.) Stochastic Modelling in Physical Oceanography. Boston, MA:Birkhauser. P. 113-140. 
Grimm, A.; S. E. T. Ferraz \& J. Gomes. 1998. Precipitation Anomalies in Southern Brazil associated with El Niño and La Niña Events. Journal of Climate, 11:2863-2880.

Grimm, A. M.; V. R. Bartros \& M. E. Doyle. 2000. Climate variability in Southern South America associated with El Niño and La Niña events. Journal of Climate, 13(1), 35-58.

Grimm, V. 1999. Ten years of individual-based modellin in ecollogy: what have we learned and what could we learn in the future? Ecological Modelling, 115:129-148.

Guerreiro, R.; E. Acha; M. Framinan \& C. Lasta. 1997. Physical oceanography of Rio de La Plata estuary, Argentina. Continental Shelf Research, 17(7):727-742.

Gwenhael, A.; P. Petitgas; P. Grellier \& P. Lazure. 2003. The selection process from larval to juvenile stages of anchovy (Engraulis encrasicolus) in the Bay of Biscay investigated by Lagrangian simulations and comparative otolith growth.Fisheries Oceanography, 12(4/5):407-418.

Haimovici, M.; J. P. Castello \& C. M. Vooren. 1996. Fisheries. In: Seeliger, U.; C. Odebrecht \& J. P. Castello (eds.) Subtropical Convergence Environments, the Coast and Sea in the Southwestern Atlantic. Berlin, Spring-Verlag. P. 183-196.

Hansen, J. E.; P. Martos \& A. Madirolas. 2001. Relationship between spatial distribution of the Patagonian stock of Argentine anchovy, Engraulis anchoita, and sea temperatures during late spring to early summer. Fisheries Oceanography, 10(2):193-206.

Harden-Jones, F. R. 1968. Fish Migration. London, Arnold. 325 p.

Hill, A. E. 1991. Advection-diffusion-mortality solutions for investigating pelagic larval dispersal. Marine Ecology Progress Series, 70:117-128.

Hinrichsen, H. H.; C. Mollmann; R. Voss; F. W. Koster \& G. Kornilovs. 2002. Biophysical modeling of larval Baltic cod (Gadus morhua) growth and survival. Canadian Journal of Fisheries Aquatic Sciences, 59:1858-1873.

Hjort, J. 1914. Fluctuations in the great fisheries of northern Europe. Rapports et Procèsverbaux des Rèunions, Conseil international pour l'Exploration de la Mer, 20:1-1228.

Hubold, G. 1982. Fish sapwning in the Southwest Atlantic in austral winter/spring 1977 and autumn 1978. Atlântica, 5(2):59.

Huggett, J.; P. Fréon; C. Mullon \& P. Penven. 2003. Modelling the transport success of anchovy Engraulis encrasicolus eggs and larvae in the southern Benguela: the effect of spatiotemporal spawing patterns. Marine Ecology Progress Series, 250:247-262.

Huston, M.; D. DeAngelis \& W. Post. 1988. New computer models unify ecological theory. BioScience, 38:682-691. 
Kousky, V. E. \& I. F. Cavalcanti. 1984. Eventos Oscilação do Sul - El Niño: Características, evolução e anomalias de precipitação. Ciência e Cultura, 36(11):1888-1899.

Letcher, B. H.; J. A. Rice; L. B. Crowder \& K. A. Rose. 1996. Variability in survival of larval fish: disentangling components with a generalized individual based model. Canadian Journal of Fisheries and Aquatic Sciences, 53:787-801.

Lima, I.D. \& J. P. Castello. 1994. Distribuicion y abundancia de la anchoita (Engraulis anchoita) en la costa sur de Brasil. Frente Maritimo, 15:87-99.

Lima, I.D. \& J. P. Castello. 1995. Distribution and abundance of South-west Atlantic anchovy spawners (Engraulius anchoita) in relation to oceanographic processes on the southern Brazilian shelf. Fish Oceanography, 4(1):1-16.

Lima, I.D.; C. A. E. Garcia \& Osmar O. Möller. 1996. Ocean surface processes on the southern Brazilian shelf: characterization and seasonal variablility. Continental Shelf Research, 16(10):1307-1317.

Lima, I. D.; D. B. Olson \& S. C. Doney. 2002a. Intrinsic dynamics and stability properties of size-structured pelagic ecosystem models. Journal of Plankton Research, 24(6):533-556.

Lima, I. D.; D. B. Olson \& S. C. Doney. 2002b. Biological response to frontal dynamics and mesoscale variability in oligotrophic environments: Biological production and community structure. Journal of Geophysical Research, 107(C8):1-21.

Lomnicki, A. 1992. Population Ecology from Individual Perspective. In: DeAngelis, D.L. \& L. J. Gross (eds.) Individual-based models and approaches in ecology. Population, communities and ecosystems. Nova York, Chapman and Hall, Inc. P. 3-17.

Lyne, D. V. \& R. E. Thresher. 1994. Dispersal and advection of Macruronus novaezealandiae (Gadiformes: Merlucciidae) larvae off Tasmania: Simulations of the effects of physical forcing on larval distribution. In: Sammarco, P. W. \& M. L. Heron (eds.) The Bio-Physics of Marine Larval Dispersal. American Geophysical Union. Washington, American Geophysical Union. P. 109-136.

Matsuura, Y. \& E. M. Kitahara. 1995 . Horizontal and vertical distribution of anchovy (Engraulis anchoita) eggs and larvae off Cape Santa Marta Grande in southern Brazil. Archive of Fishery and Marine Research, 42(3):239-250.

Mechoso, C. R. \& G. Pérez-Iribarren. 1992. Streamflow in southeastern South América and the Southern Oscillation. Journal of Climate, 5:1535-1539.

Melo, M. J. 1978. Estimativa preliminar da biomassa e do potencial pesqueiros de engraulídeos na região sul do Brasil. Série documentos técnicos [do] Programa de Pesquisa e Desenvolvimento Pesqueiro do Brasil/SUDEPE,29:6-40. 
Miazan, H.; M. Pájaro; G. Alvarez Colombo \& A. Madirolas. 2001. Feeding on survivalfood: gelatinous plankton as a source of food for anchovies. Hydrobiologia, 451:45-53.

Möller, O. O.; P. S. G. Paim \& I. D. Soares. 1991. Effects and mechanisms of water circulation in the Patos Lagoon Estuary. Bulletin Institute Géologique, 49:15-21.

Möller, O. O. 1996. Hydrodynamique de la Lagune dos Patos (30º S, Brésil). Mesures et modélisation. Tese de Doutorado. Universidade de Bordeaux, 200 p.

Möller, O. O. \& P. Casting. 1999. Hydrographical Characteristics of the Estuarine Area of Patos Lagoon (30S, Brazil). In: Perillo, G. M. E.; M. C. Piccolo; M. P. Quivira (eds.). Estuaries of South America. Berlim, Springer-Verlag. P 83-100.

Montú, M.; I. M. Gloeden; A. K. Duarte \& C. Resgalla Jr. 1996. Zooplancton. In: Seeliger, U.; C. Odebrecht \& J. P. Castello (eds.). Subtropical Convergence Environments: The Coast and Sea in the Southwestern Atlantic. Berlim, Springer-Verlag. P. 110-114.

Muelbert, J.H. \& C. Sinque. 1995. Processos oceanográficos e a distribuição de larvas de peixes na plataforma continental sul brasileira. Anais do VI Colacmar. Mar del Plata, Argentina. P. 140.

Mullon, C.; P. Cury \& P. Penven. 2002. Evolutionary individual-based model for the recruitment of anchovy (Engraulis capensis) in the southern Benguela. Canadian Journal of Fisheries Aquatic Sciences, 59:910-922

Mullon, C.. P. Fréon. C. Parada. C. Van Der Lingen \& J. Huggett. 2003. From particles to individuals: modelling the early stages of anchovy (Engraulis capensis/encrasicolus) in the southern Benguela. Fisheries Oceanography, 12(4/5):396-406.

Murdoch, W. W.; E. McCauley; R. M. Nisbet; W. S. C. Gurney \& A. M. de Roos. 1992. Individual-Based Models: Combining Testability and Generality. In: DeAngelis, D.L. \& L.J. Gross (eds.) Individual-based models and approaches in ecology. Population, communities and ecosystems. Nova York, Chapman and Hall, Inc. P. 18-35.

Neto, D. F. U. 1999. Dinâmica da Plataforma Continental Média do Rio Grande do Sul. Monografia de graduação. Fundação Universidade Federal do Rio Grande, Departamento de Oceanografia, $46 \mathrm{p}$.

O'Connor, W. P. 1991. A numercial model of tides an storm surges in the Rio de la Plata Estuary. Continental Shelf Research, 11(12):1491-1508.

Odebrecht, C. \& V. M. T. Garcia. 1996. Phytoplankton. In: Seeliger, U.; C. Odebrecht \& J. P. Castello P. (eds.). Subtropical Convergence Environments, the Coast and Sea in the Southwestern Atlantic. Berlim, Springer-Verlag. P. 183-196.

Okubo, A. 1994. The role of diffusion and related physical processes in dispersal and recruitment of marine populations. In: Sammarco, P. W. \& M. L. Heron (eds.) The Bio-Physics 
of Marine Larval Dispersal. American Geophysical Union. Washington. P. 5-32.

Oliveira, L. A.; V. A. F. Costa \& B. R. Baliga. 2002. A Lagrangian-Eulerian model of particle dispersion in a turbulent plane mixing layer. International Journal for Numerical Methods in Fluids, 40(5):639-653.

Olson, D. B.; G. P. Podesta; R. H. Evans \& O. B. Brown. 1988. Temporal variations in the separation of Brazil and Malvinas Currents. Deep-Sea Research, 35:1971-1990.

Ozgokmen, T. M.; A. Griffa \& A. J. Mariano. 2000. On the Predictability of Lagrangian Trajectories in the Ocean. Journal of Atmospheric and Oceanic Technology, 17:366-383.

Palma, E. D.; R. P. Matano \& A. R. Piola. 2005. A Numerical study of the Southwestern Atlantic Shelf Circulation: The baroclinic response. Manuscrito em preparação.

Palma, E. D.; R. P. Matano \& A. R. Piola. A numerical study of the southwestern atlantic shelf circulation. Part I: The barotropic response to tidal and wind forcing. Submetido ao Journal of Geophysical Research.

Palma, E. D.; R. P. Matano \& A. Piola. 2004. A Numerical Investigation of the Southwestern Atlantic Continental Shelf Circulation, EOS Transactions, AGU, 84(52), Ocean. Sci. Meet. Suppl., Abstract, American Geophysical Union.

Palma, E. D.; R. P. Matano \& A. Piola. 2004. A comparison of the circulation patterns over the Southwestern Atlantic Shelf driven by different wind stress climatologies. Geophysical Research Letters, 31:L24303.

Parada, C.; C. D. Van Der Lingen; C. Mullon \& P. Penven. 2003. Modelling the effect of buoyancy on the transport of anchovy (Engraulis capensis) eggs from spawning to nursey grounds in the southern Benguela: an IBM approach. Fisheries Oceanography, 12(3):170184.

Pedersen, O. P; D. Slagstad \& K. S. Tande. 2003. Hydrodynamic model forecasts as guide for process studies on plankton and larval fish. Fisheries Oceanography, 12(4/5):369-380.

Pereira, C. S. 1989. Seasonal variability in the coastal circulation on the Brazilian continental shelf (29S - 35S). Continental Shelf Research, 9(3):285-299.

Phonlor, G. 1984. Morfologia e biologia de larvas de (Engraulis anchoita) (Hubbs \& Marini), (Osteichtyes, Engraulidade). Atlântica, 7:85-98.

Pimenta, F. M. 2001. Estudo numérico da influência da descarga fluvial e dos ventos sobre a dinminica da pluma do Rio da Prata. Tese de mestrado. Universidade de São Paulo, Departamento de Oceanografia Física.

Piola, A. R.; E. J. D. Campos; O. O. Moller Jr.; M. Charo \& C. Martinez. 2000. The subtropical shelf front off eastern South America. Journal of Geophysical Research, C3(105):65656579 . 
Piola, A. R.; R. P. Matano; E. D. Palma; O. O. Möller Jr. \& E. J. D. Campos. 2005. The influence of the Plata River discharge on the western South Atlantic shelf. Geophysical Research Letters, 32:L01603.

Press, W. H.; W. T. Vetterling; S. A. Teukolsky \& B. P. Flannery. 1994. Numerical Recipes in Fortran. The Art of Scientific Computing. Cambridge, Cambridge University Press. 722 p.

Rao, V. B. \& K. Hada. 1990. Characteristics of Rainfall over Brazil: Annual Variations and Connections with the Southern Oscillation. Theoretical and Applied Climatology, 42 (2): 81-91.

Reis, E. G. \& F. D'Incao. 2000. The present status of artesanal fisheries of extreme Southern Brazil: an effort towards community-based management. Ocean \& Coastal Management, 43: 585-595.

Rivas, L. A. 1997. Current-Meter observations in the Argentine Continental Shelf. Continental Shelf Research, 17(4):391-406.

Ropelewski, C. F. \& M. S. Halpert. 1987. Global and regional scale precipitation patterns associated with the El Niño/ Southern Oscillation. Monthly Weather Review, 115(8):16061626.

Sanchez, R. P \& J. D. de Ciechomski. 1995. Spawning and nursery grounds of pelagic fish species in the sea-shelf off Argentina and adjacent areas. Scientia Marina, 59(3-4):455-478.

Sanchez, R. P. 1989. Synopsis on the reproductive biology and early life of Engraulis anchoita, and related environmental conditions in Argentine waters. IOC Workshop Report, 65(Anexo V):5-49.

Sebastiao, P. \& C. G. Soares. 1995. Modeling the fate of oil spills at sea.Spill Science \& Technology Bulletin, 2:121-131.

Sentchev, A. \& K. Korotenko. 2004. Stratification and tidal current effects on larval transport in the eastern English Channel: Observations and 3D modeling. Enviromental Fluid Mechanics, 4:305-331.

Sharma, A.; D. Kashyap \& G. L. Asawa. 2001. New MOC model of seawater transport in coastal aquifers. Journal of Hydrologic Engineering, 6(5):382-396.

Smith, R. D. \& D. T. Sandwell. 1997. Global sea floor topography from satellite altimetry and ship depth soundings. Science, 277:1956-1962.

Sinclair, M. 1988. Marine Populations: An Essay on Population Regulation and Speciation. Washington, Washington Sea Grant Program. 252 p.

Sinque, C. \& J. H. Muelbert. 1996. Ichthyoplankton. In: U. Seeliger, C. Odebrecht \& J. 
P. Castello (eds.). Subtropical Convergence Environments: The Coast and Sea in the Southwestern Atlantic. Berlim, Springer-Verlag. P. 120-123.

Skogen, M. D.; L. F. Shannon \& J. E. Stiansen. 2003. Drift patterns of anchovy Engraulis capensis larvae in the southern Benguela, and their possible importance for recruitment. African Journal of Marine Science, 25:37-47.

Soares, I. \& O. O. Moller. 2001.Low-frequency currents and water mass spatial distribution on the southern Brazilian shelf.Continental Shelf Research,21:1785-1814.

Soares, I. D. 2003. The southern brazilian shelf buouancy-driven currents. Tese de Doutorado. Universidade de Miami, Rosentiel School of Marine and Atmospheric Science. 353 p.

Soutar, A. \& J. D. Isaacs. 1974. Abundance of pelagic fish during the 19th and 20 th centuries as recorded in anaerobic sediment off the Californias. Fishery Bulletin U. S, 72(2):257-273.

Souza, R. B. \& I. S. Robinson. 2004. Lagrangian and satellite observations of the Brazilian Coastal Current. Continental Shelf Research,24:241-262.

Thomson, D. J. 1986. A random walk model of dispersion in turbulent flows and its application to dispersion in a valley. Quarterly journal of the Royal Meteorological Society, 112:511-530.

Trenberth, K. E.; W. G. Large \& J. G. Olson. 1990. The mean annual cycle in global wind stress. Journal of Physical Oceanography, 20:1742-1760.

Valentin, J. L. 1984. A Ressurgência, Fonte de vida dos oceanos. Ciência Hoje,18(102):1925 .

van Dop, H. \& F. T. M. Nieuwstadt. 1985. Random walk models for particle displacements in inhomogeneous unsteady turbulent flows. Physics of Fluids, 28(6):1639-1653.

Vasconcellos, M. C. 1994. Distribuição, crescimento e mortalidade de larvas de anchoita (Engraulis anchoita) no Sul do Brasil. Dissertação de Mestrado. Fundação Universidade Federal de Rio Grande, Departamento de Oceanografia. 127 p.

Vaz, A. C.; O. O. Möller \& T. L. de Almeida. Quantificação da descarga dos principais afluentes da Lagoa dos Patos. Submetido à revista Atlântica.

Vieira, E.F. \& S.R.S. Rangel. 1988. Planície costeira do Rio Grande do Sul: Geografia física, vegetação e dinâmica sócio-demográfica. Porto Alegre, Sagra Edt. 256p.

Wainer, I.; P. Gent \& G. Goni. 2000. Annual cycle of the Brazil-Malvinas confluence region in the National Center for Atmospheric Research Climate System Model. Journal of Geophysical Research, 105(11):26167-26177.

Weiss, G. \& J. A. F. Souza. 1977. Desova invernal de Engraulis anchoita na costa sul do 
Brasil em 1970 e 1976. Atlântica, 2(2):5-24.

Weiss, G.; J. A. F. Souza \& A. Santos. 1976. Contribuicao ao conhecimento do ictioplâncton marinho da Plataforma Sul do Brasil. Atlântica, 1(1/2):7-78.

World Ocean Atlas 2001 (one-degree objectively analyzed fields and statistics) http:/ www.nodc.noaa.gov/ (30 de maio de 2005)

Zambianchi, E. \& A. Griffa. 1994. Effects of finite scales of turbulence on dispersion estimates. Journal of Marine Research, 52:129-148.

Zavialov, P. O.; R. D. Ghisolfi \& C. A. E. Garcia. 1998. An inverse model for seasonal circulation over the Southern Brazilian Shelf: Near-Surface Velocity from the Heat Budget. Journal of Geophysical Research, 28:545:562.

Zavialov, P. O. \& O. O. Möller. 2000. Modeling and observations of currents off Southern Brazil and Uruguay: the Rio Grande Current. In: Zatsepin A. G. (Ed.) Oceanic Fronts and Related Phenomena (Proceedings of the Fedorov International Memorial Symposium) IOC Workshop Report No. 159, UNESCO, GEOS, Moscou. P. 612-617.

Zavialov, P. O.; O. O. Moller \& E. J. D. Campos. 2002. First direct measurements of currents on the continental shelf of Southern Brazil. Continental Shelf Research, 22:1975-1986. 